\title{
The mineral deposits of Panama: Arc metallogenesis on the trailing edge of the Caribbean large igneous province
}

\author{
Los depósitos minerales de Panamá: Metalogénesis de Arco en el borde posterior de la gran \\ provincia ígnea del Caribe
}

\author{
Stewart D. Redwood ${ }^{1, *}$
}

Consulting Economic Geologist, P.O. Box 0832-0757, World Trade Center, Panama City, Panama

* Corresponding author: (S. Redwood) mail@sredwood.com

\section{How to cite this article:}

Redwood, S., 2020, The Mineral Deposits of Panama: Arc metallogenesis on the trailing edge of the Caribbean Large Igneous Province: Boletín de la Sociedad Geológica Mexicana, 72 (3), A130220. http://dx.doi.org/10.18268/ BSGM2020v72n3a130220

Manuscript received: November 10, 2019 Corrected manuscript received: January 30, 2020 Manuscript accepted: February 11, 2020

Peer Review under the responsability of Universidad Nacional Autónoma de México.

This is an open access article under the CC BY-NC-SA license(https://creativecommons.org/licenses/by-nc-sa/4.0/)

\section{ABSTRACT}

The mineral deposits of the Panama microplate are hosted by a composite volcano-plutonic island arc of Late Cretaceous to Quaternary age developed on an oceanic plateau, the Caribbean Large Igneous Province (CLIP), on the western, trailing edge of the Caribbean Plate. Large ioneous provinces are formed by gold and chalcophile element-enriched, mantle plume-related magmas, which may explain the strong metal endowment of Panama of about $32 \mathrm{Mt}$ copper and $>984 \mathrm{t}$ gold. The progressive collision of the Panama arc with South America since the middle Eocene resulted in deformation and oroclinal bending of the arc and metallogenic belts. In western Panama, the copper-gold belts young from south to north away from the subduction zone, whereas in eastern Panama the belts young from north to south. An Early Arc of late Campanian to Eocene age (71-34 Ma) developed related to northerly subduction of the Farallon Plate. It has submarine Si-Mn-Fe exhalite deposits in the Nombre de Dios and Montijo belts with showings of Au-rich VMS Cu-Zn mineralization. The San Blas porphyry $\mathrm{Cu}-\mathrm{Au}$ belt formed in eastern Panama (Rio Pito and other porphyry Cu-Au prospects), while the western continuation, offset by 200 $\mathrm{km}$ sinistrally to the Azuero Belt, hosts high sulphidation epithermal Au-Cu deposits (Cerro Quema and others) in porphyry lithocaps. The arc migrated to the northern Azuero-Soná belt in the middle to late Eocene with the formation of epithermal $\mathrm{Au}-\mathrm{Ag}$-Pb-Cu mineralization, and a porphyry Au prospect (Soná). A Middle Arc developed in the Oligocene to lower Miocene (31-18 Ma) related to the NE-dipping subduction of the Farallon Plate followed by the Nazca Plate. In eastern Panama, the arc formed intermediate sulphidation epithermal $\mathrm{Au}$ deposits in high grade breccias (Espiritu Santo de Cana mine) and carbonates (Rio Mogue prospect), and porphyry $\mathrm{Cu}$ mineralization (Ipeti). The eastern Panama arc shut down in the lower Miocene as a result of the change of the Nazca Plate convergence to strike slip. The Middle Arc in western Panama, on the northern side of the Central Cordillera, hosts the Petaquilla belt of porphyry $\mathrm{Cu}$ (the supergiant Cobre Panama porphyry $\mathrm{Cu}-\mathrm{Mo}-\mathrm{Au}-\mathrm{Ag}$ deposit) and epithermal $\mathrm{Au}$ (Molejon) deposits, and probably the epithermal Au deposits of the Veraguas belt. The Later Arc of Miocene to Quaternary age (18-0 Ma) of the Central Cordillera of western Panama hosts low sulphidation epithermal Au vein and breccia-hosted deposits (Capira, Remance, Santa Rosa), high sulphidation epithermal Au deposits (Cerro Lloron, Rio Liri), and porphyry Cu deposits (the supergiant Cerro Colorado porphyry $\mathrm{Cu}-\mathrm{Mo}-\mathrm{Au}-\mathrm{Ag}$ deposit and the Cerro Chorcha porphyry $\mathrm{Cu}-\mathrm{Au}$ deposit). Uplift of the young porphyries in the western part of the belt is related to the subduction of the Cocos aseismic oceanic ridge. Deposits formed by Quaternary weathering include lateritic bauxite and iron ore in the Chiriqui-Veraguas belt; heavy mineral Fe-Ti sands in beach/marine placer deposits in the Gulf of Panama; and extensive placer Au deposits in Northern Darien, Darien, Chepo, Coclé, Veraguas, western Azuero-Soná, and many other small deposits.

Keywords: epithermal gold, porphyry copper, manganese, metallogenic belts, Caribbean
Large Igneous Province (CLIP).

\section{RESUMEN}

Los depósitos minerales de la microplaca de Panamá están hospedados en un arco de isla volcáno-plutónico de edad Cretácico tardio al Cuaternario desarrollado en una meseta oceánica, la Gran Provincia Ignea del Caribe, en el borde occidental de la Placa del Caribe. Las grandes provincias igneas están formadas por magmas enriquecidos en oro y elementos calcófilos en una columna de convección del manto, lo que puede explicar la fuerte dotación de metal de Panamá de $32 \mathrm{Mt}$ de cobre y $>984 t$ de oro. La colisión progresiva del arco de Panamá con América del Sur desde el Eoceno medio provocó la deformación y la flexión oroclinal del arco y los cinturones metalogénicos. Un Arco Temprano de edad Campaniano tardío al Eoceno (71-34 Ma) se desarrolló por la subducción hacia el norte de la placa Farallón. Tiene depósitos exhálativos submarinos de $\mathrm{Si}-\mathrm{Mn}$-Fe en los cinturones $\mathrm{Nombr}$ de Dios y Montijo y ocurrencias de mineralización tipo $V M S$ de Cu-Z̈n rico en Au. El cinturón de Cu-Au de pórfido de San Blas se formó en el este de Panamá (Rio Pito), mientras que la continuación occidental, desplazada por $200 \mathrm{~km}$ a la izquierda al Cinturón de Azuero, hospeda depósitos epitermales de Au-Cu de alta sulfuración (Cerro Quema) en litocapas de pórfido. El arco migró al cinturón norte de Azuero-Soná en el Eoceno medio a tardío y tiene mineralización epitermal $A u-A g-P b-C u$ y un prospecto de pórfido de Au (Soná). Un Arco Mediano se desarrolló en el Oligoceno al Mioceno inferior (31-18 Ma) relacionado con la subducción al NE de la Placa de Farallón seguida de la Placa de Nazca. En el este de Panamá, el arco formó depósitos de Au epitermales de sulfuración intermedia en brechas de alto grado (Espiritu Santo de Cana) y carbonatos (Rio Mogue), y mineralización de pórfido de Cu (Ipeti). El arco del este de Panamá se termino en el Mioceno inferior como resultado del cambio de la convergencia de la Placa de Nazca a un margen de falla de rumbo. El Arco Mediano en el oeste de Panamá, en el lado norte de la Cordillera Central, tiene el cinturón de pórfido de Cu de Petaquilla (Cobre Panamá) y depósitos epitermales de Au (Molejón), y probablemente los epitermales de Au del cinturón de Veraguas. El Arco Tardío del Mioceno a Cuaternaria (18-0 Ma) de la Cordillera Central del oeste de Panamá tiene depósitos de vetas y brechas epitermales de Au de baja sulfuración (Capira, Remance, Santa Rosa), depósitos de Au epitermales de alta sulfuración (Cerro Llorón, Río Liri) y depósitos de pórfido Cu-Mo \pm Au (Cerro Colorado, Cerro Chorcha). El levantamiento de los pórfidos jóvenes en la parte occidental del cinturón está relacionado con la subducción de la cresta oceánica asísmica de Cocos. Los depósitos formados por la meteorización cuaternaria incluyen bauxita laterítica mineral de hierro en el cinturón de Chiriqui-Veraguas; arenas de minerales pesados de Fe-Ti en depósitos de playa / placer marino en el Golfo de Panamá; y extensos depósitos aluviales de Au.

Palabras clave: oro epitermal, pórfido de cobre, manganeso, cinturónes metalógenicos, Provincia Ígnea Grande del Caribe (CLIP). 


\section{Introduction}

The Iisthmus of Panama has a rich endowment of porphyry copper and epithermal gold deposits, including two supergiant porphyries $(>10 \mathrm{Mt} \mathrm{Cu}$; Clark, 1993), both of which are also giant gold deposits (>100 t Au; Singer, 1995), which have formed from the Late Cretaceous to the Quaternary. The total metal endowment (historical production plus resources) of the isthmus is about $32 \mathrm{Mt} \mathrm{Cu}$ and $>984$ t (31.6 Moz) Au, which does not account for much of the historic gold production (Tables 1, 2 and 4). The multiple volcanic-arc related gold and copper metallogenic belts developed on the trailing edge of a large igneous province (LIP), the oceanic plateau of the Caribbean Large Igneous Province (CLIP), interpreted to have formed at the Galapagos mantle hot-spot. Oceanic plateaus are enriched in metals compared to normal oceanic crust and probably contributed metals to the metal endowment of the isthmus. The metallogenic belts of the isthmus record the initiation of subduction, the metallogenic evolution of the island arc, the change to highly oblique subduction, and the cessation of subduction and volcanism in the eastern part. The contrasting distribution of metallogenic belts in eastern and western Panama is the result of oroclinal deformation which bent the isthmus into a recumbent S-shape during the protracted history of collision with the North Andes Block of the South American plate, which also resulted in the formation of the isthmus and the closure of the Central American Seaway (Figure 1).

This paper describes the geology and history of mineral deposits (those with mineral resource estimates and/or significant historical mining) and prospects (mineral occurrences without significant mining or sufficient work to define resources) of Panama. The topography and place names of Panama are shown in Figure 2 and the locations of the principal mineral deposits are shown in Figure 3 and are listed in Tables 1 to 4. The deposits and prospects are described by metallogenic belts from oldest to youngest, and within each belt from east to west. The deposit and prospect descriptions are based on the published literature, historical newspapers, company press releases, Canadian Securities Administrators' NI 43-101 technical reports published on Sedar (www.sedar.com), and company archives (Thayer Lindslay Papers, American Heritage Center, University of Wyoming), as well as the author's quarter century plus experience of exploration in Panama.

\section{Exploration and mining history of Panama}

Panama has a long and fascinating history of mining over almost two millennia since pre-Columbian times, as described in a companion paper (Redwood, 2020) and by others (Carles, 1962; Mérida, 1973; Castillero Calvo, 2008, 2019; Mendez, 2013). Mining was dominated by gold for most of this history and Panama was one of the richest gold provinces of the Spanish empire in the $16^{\text {th }}-18^{\text {th }}$ centuries. Major porphyry copper deposits were discovered in the mid- $20^{\text {th }}$ century, and the start of copper production at First Quantum's Cobre Panama mine in 2019 marked the transformation of Panama to become a major copper producer. Panama currently produces copper, gold, silver and molybdenum, is a past producer of manganese and iron ore, and also has resources of bauxite.

Exploration and mining in Panama can be divided into five historical periods: 1) pre-Columbian gold mining from about $100 \mathrm{CE}-1501$; 2) the Spanish colonial period of gold mining, 15011821; 3) the Republican period of gold mining from 1821-1942, with manganese mining from 1871, firstly as part of Colombia and from 1903 as Panama, until gold mining was halted by World War Two; 4) the period of porphyry copper discoveries and regional exploration programs from 1957 to 1982; and 5) the development of modern gold and copper exploration and mining from 1985 to the present. 


\section{Regional geological setting of Panama}

Panama is located at the junction of the Cocos, Nazca, Caribbean and South American Plates (Figure 1). Panama was formed as a volcanic arc on the southwestern, trailing edge of the Caribbean Plate from the late Campanian, related to the northerly subduction of the Farallon Plate, and later the Nazca Plate. The southeastern or Chocó part of the arc collided with the South American Plate and was accreted to the Northern Andes to form part of the Western Cordillera of Colombia, while the western part forms the Isthmus of Panama, part of the Central America land bridge (Cediel et al., 2003; Cediel and Shaw, 2019; Redwood, 2019). Collision was oblique, propagated to the northwest and is ongoing (Barat et al., 2014).

The Chocó Block (or Panama-Chocó arc or terrane) is defined as the part of Panama east of the Panama Canal, and extends into the Chocó
Province of Colombia, while the Chorotega Block forms western Panama and Costa Rica. Both blocks are underlain by oceanic plateau volcanic rocks and are grouped together as the Panama Microplate (Kellogg and Vega 1995; Trenkamp et al., 2002). This formed after collision with South America and it was detached from the Caribbean Plate by the North Panama Deformed Belt, from the Nazca Plate by the South Panama Deformed Belt, from the South American Plate by the East Panama Deformed Belt, and from the Cocos Plate by the Middle America subduction zone. The Cocos Plate is being subducted beneath Central America and the western part of the Panama Microplate at a rate of about $72 \mathrm{~mm}$ /year along the Middle America Trench (Trenkamp et al., 2002). The aseismic Cocos oceanic ridge is being subducted beneath the isthmus at the Panama-Costa Rica border. The boundary between the Cocos and Nazca Plates is the Panama Fracture Zone, which includes the Coiba and Balboa Fracture

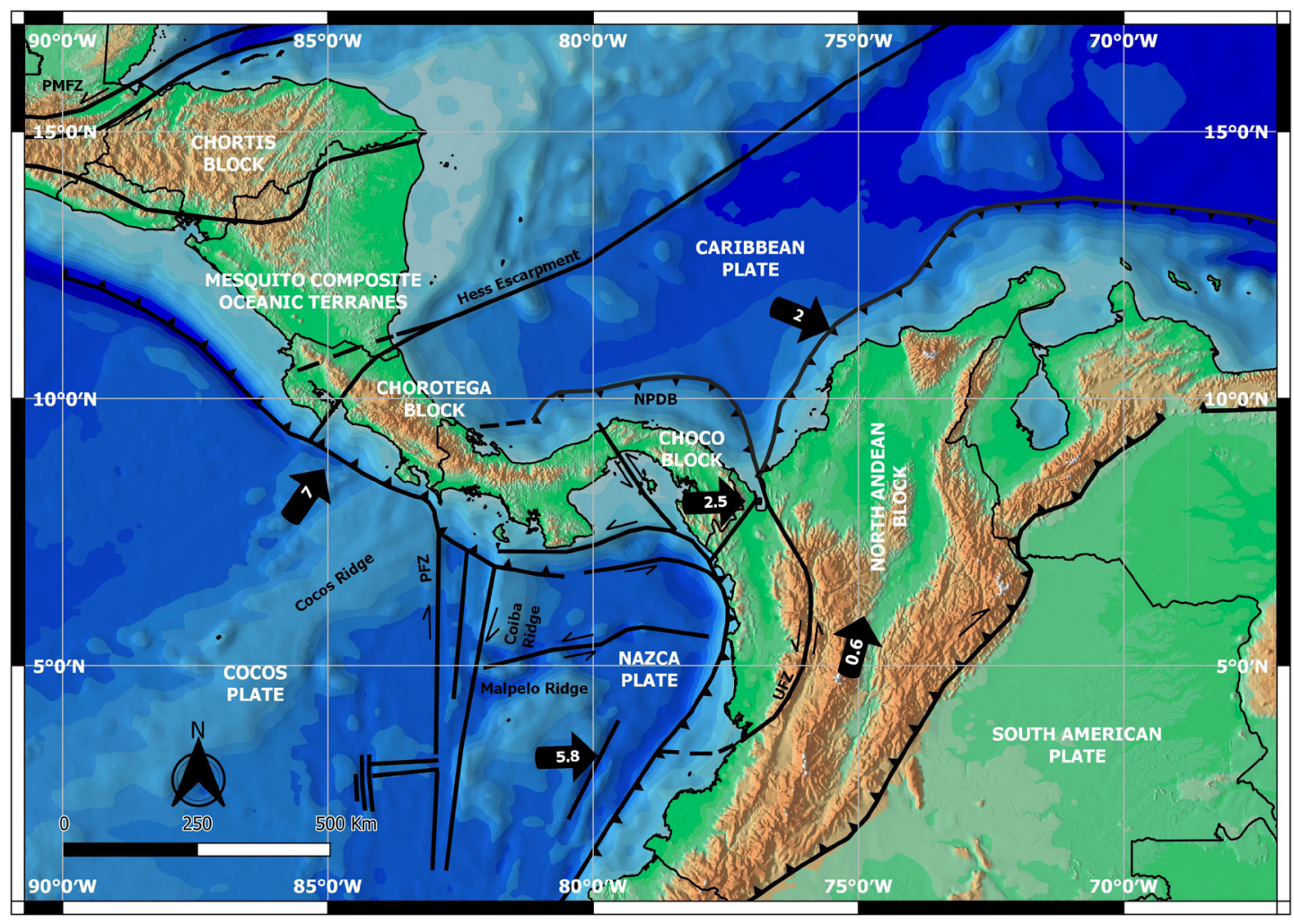

Figure 1 The plate tectonic setting of Panama. Black arrows show present-day GPS velocities (cm/y) relative to stable South America (Trenkamp et al., 2002). PFZ, Panama Fracture Zone; NPDB, North Panama Deformed Belt; UFZ, Uramita Fault Zone. 
Zones, which are north-trending, seismically active, right-lateral oceanic transform faults (Westbrook et al., 1995).

The Caribbean lithosphere is interpreted to be Pacific-derived and was trapped between the Americas during their westward drift as the Atlantic Ocean opened (Pindell et al., 2005). This began at about $120 \mathrm{Ma}$ with the development of a west-dipping subduction zone between Central America and the northern Andes. The mainly 90 Ma Caribbean basalts were extruded onto pre-existing Caribbean crust about 30 My later to form the Caribbean Large Igneous Province (CLIP) oceanic plateau, which is interpreted to have formed at the Galapagos hot spot (Pindell et al., 2005).

The southern margin of Panama is characterized by a long-lived, intra-oceanic subduction zone since the Late Cretaceous as a result of the northwards subduction of the Farallon Plate beneath the Caribbean Plate. Subduction continued until the early Miocene breakup of the Farallon Plate. Episodic accretion of oceanic islands occurred from the Late Cretaceous to the middle Eocene (Buchs et al., 2010, 2011b).

The southern boundary of the Panama Microplate changes from oblique ENE-directed subduction in the west $(50 \mathrm{~mm} / \mathrm{y})$ to a sinistral strike-slip fault east of the Azuero Peninsula, marked by a lack of seismicity, due to a change in the strike of the margin (Kellogg and Vega 1995; Mann 1995; Westbrook et al., 1995). The Nazca Plate is bounded to the north by the South Panama Deformed Belt, an accretionary prism which has filled the trench in the eastward continuation of the Middle America Trench (Defant et al., 1991a). Westbrook et al. (1995) estimated that the present tectonic regime started at about $3.5 \mathrm{Ma}$ based on the $140 \mathrm{~km}$ displacement along the Southern Panama Fault Zone, while Lonsdale and Klitgord (1978) suggested that strike-slip motion started in the late Miocene between 12 and $8 \mathrm{Ma}$ and resulted in the cessation of subduction along the southern margin of eastern Panama. As a consequence of the lack of subduction, there is no active volcanic arc in eastern Panama, where the youngest volcanism occurred at $15 \mathrm{Ma}$ (Montes et al., 2011).
The northern boundary of the Panama microplate is defined by the underthrusting or flat subduction at $10 \mathrm{~mm}$ /year (Reed and Silver 1995) of the Caribbean Plate along the north side of North Panama Deformed Belt, a wide accretionary wedge, which has been actively forming since the middle Miocene. Camacho et al. (2010) showed the existence of amagmatic subduction of the Caribbean Plate with a southward-dipping Wadati-Benioff Zone to a depth of $80 \mathrm{~km}$ beneath the isthmus.

\section{Geological evolution and magmatic arcs of the Panama Microplate}

The ages of oceanic crust and magmatic arcs of Panama are shown in Figure 4 based on compilations of radiometric age dating (Lissinna, 2005; Wegner et al., 2011; Montes et al., 2012a; Corral et al., 2012, 2016; Perelló et al., 2020).

Basalts from the accreted oceanic plateau of the Caribbean Large Igneous Province of Aptian to Campanian age (115-71 Ma) occur in eastern Darien and the southern Azuero and Soná Peninsulas, and accreted ocean island basalts (66-17 Ma) occur to the south of the CLIP in Azuero and Soná (Buchs et al., 2011b).

The volcano-plutonic island arcs are designated in this paper as the Early Arc (71-34 Ma), Middle Arc (31-18 Ma) and Late Arc (18-0 Ma) following Whattam et al. (2012) with some modification of the ages (Lissinna, 2005; Wegner et al., 2011; Montes et al., 2012a; Corral et al., 2012, 2016; Perelló et al., 2020); most other authors include the Middle Arc with the Late Arc and describe only Early and Late Arcs (e.g. Montes et al., 2012a; Buchs et al., 2019b).

A Late Cretaceous (Campanian) to Eocene island arc, the Early Arc, developed on the trailing edge of the CLIP during northerly or north-easterly subduction of the Farallon Plate, forming the volcano-plutonic arcs mapped in the San Blas, Chagres and Mamoní mountains (the San Blas arc), and continues in the Azuero Peninsula with a ca 200 $\mathrm{km}$ left-lateral offset as measured along a NW-SE trend between the southern side of the San Blas arc and the southern side of the Azuero arc. To the 
southeast, the arc continues as the Acandi-Mande batholiths in Colombia, now accreted to the Western Cordillera of the Northern Andes. The Early Arc can be subdivided into a Campanian to early Eocene arc (71-48 Ma) and a middle to late Eocene arc (47$34 \mathrm{Ma})$.

The latter occurs in the northern part of the Azuero and Soná Peninsulas, in the Petaquilla district (Redwood et al., 2021) and Portobello. Arc magmatism ceased in the San Blas arc in the middle Eocene (ca. 47-42 Ma), coincident with uplift as shown by fission track ages (Farris et al., 2011; Montes et al., 2012a; Ramirez et al., 2016). The arc remained active to the west in the Azuero-Soná Peninsula where it migrated northwards.

The Early Arc shows curvature and left lateral displacement between eastern and western Panama. Using the Campanian-Eocene arc as a strain marker, Montes et al. (2012a) showed the development of an oroclinal bend to give Panama its recumbent $\mathrm{S}$ shape by vertical axis rotation of blocks and strike slip faulting. Rotation and bending started during the late Eocene - early Oligocene (38-28 Ma) and was almost completed by the late Oligocene $(\sim 25 \mathrm{Ma})$, and coincided with a magmatic gap in eastern Panama from 38-28 Ma (Montes et al., 2012a), although this may be an artefact from lack of dating.

Coincident with arc shutdown in the middle Eocene, there was a change in the tectonic regime of eastern Panama from compressional to extensional resulting in the formation of a fore-arc in the Chuqunaque-Tuira Basin. The extension and arc break-up may be explained by either steepening of the subducting Farallon Plate by slab roll-back and ultimately break-off (Whattam et al., 2012), or by the start of interaction of the Panama-Chocó Arc with South America (Barat et al., 2014; Montes et al., 2019). The Farallon Plate broke up at 25-23 Ma (late Oligocene) to form the Nazca and Cocos Plates (Barat et al., 2014). NE-dipping subduction of the Farallon Plate and then the Nazca Plate jumped to the south and initiated the Middle Arc (31-18 $\mathrm{Ma})$ in the late Oligocene in the Darien and Majé mountains, the Pearl Islands (Lissinna, 2005; Wegner et al., 2011), the Central Panama Volcanic Field (Buchs et al., 2019a), and the Petaquilla batholith and porphyries on the northern side of the Central Cordillera (Baker et al., 2016). Magmatism ceased by the early to middle Miocene in eastern Panama due to the change in the Nazca Plate convergence to strike-slip, but continued in the Central Cordillera as the Late Arc until the Quaternary. The initial oblique collision of the Panama-Chocó arc with the North Andean Block occurred between 40-12 $\mathrm{Ma}$, and collision of the Chocó Block of Colombia was complete by about the early Miocene (Mann and Kolarsky, 1995; Coates et al., 2004; Montes et al., 2012; Barat et al., 2014; Montes et al., 2015, 2019). Transpressive deformation formed the East Panama Deformed Belt in the Darien region since the middle Miocene as the Panama Microplate collided against South America, with a current motion of $1.6-1.7 \mathrm{~mm} / \mathrm{yr}$, with the recent break-off of the Choco block (Kellogg et al., 2019).

The Late Arc comprises the Miocene volcanic arc (18-5 Ma) which forms the Central Cordillera of western Panama, and the Pliocene-Quaternary volcanic arc (5-0 Ma) which is superimposed on the Miocene arc and has 10 major stratocones and 31 domes and cones over a length of $400 \mathrm{~km}$ which extends from the El Valle stratovolcano, located west of the Panama Canal, westwards to the El Barú volcano close to Costa Rica (de Boer et al., 1988, 1991). The El Valle, La Yeguada and El Barú volcanos are active, with historical eruptions and micro-seismic activity on the latter (Morrell et al., 2013).

\section{The Metallogenic Belts of Panama}

A few mineral deposits have radiometric age dating, and the age of the others is inferred by the age of their volcanic-intrusive host rocks on the assumption of a genetic relationship. There may well be changes in some inferred deposit ages if dating of them is carried out in the future, especially in poorly known areas such as Darien and San Blas. The following metallogenic belts are defined in this paper as a framework for the descriptions of the mineral deposits (Figure 5) and comprise three exhalite Si-Mn-(Fe) and Au-Cu-Zn VMS belts, and ten porphyry copper and epithermal gold belts: 


\subsection{EARLY ARG (LATE GAMPANIAN-EOGENE, 71-34 Ma)}

- Nombre de Dios Belt and Chagres-Mamoni Belt: exhalite Si-Mn-(Fe) deposits and Au-Cu-Zn VMS prospects.

- Montijo Belt (Azuero): exhalite Si-Mn-(Fe) prospects.

- San Blas Belt: porphyry Cu prospects (Rio Pito and others).

- Azuero-Soná Belt: high sulphidation epithermal Au-Cu deposits (Cerro Quema) and lithocaps with porphyry $\mathrm{Cu}-\mathrm{Au}$ potential, low sulphidation epithermal Au (Los Pozos, Cerro Negro), and porphyry $\mathrm{Au}$ (Soná).

\subsection{MIDDLE ARG (OLIGOGENE-LOWER MIOGENE, 31-18 Ma)}

- Darien Belt: intermediate sulphidation epithermal Au deposits (Espiritu Santo de Cana, Rio Mogue) and porphyry $\mathrm{Cu}$ prospects (Cana, Ipeti).

- Central Panama Belt: low to intermediate sulphidation epithermal Au deposits (Emperador, Santa Rita).

- Petaquilla Belt: porphyry Cu-Mo (Cobre Panama, Palmilla) and low sulphidation epithermal $\mathrm{Au}$ deposits (Molejon).
- Veraguas (Santa Fé) Belt: low sulphidation epithermal Au deposits (Margaja).

\subsection{LATE ARG (MIOGENE TO QUATERNARY, 18-0 Ma)}

- El Valle Belt: low sulphidation epithermal Au deposits (Capira, Cacao) and high sulphidation epithermal Au prospects (Cerro Lloron).

- Central Veraguas Gold Belt: low sulphidation epitermal Au deposits (Remance, Santa Rosa) and high sulphidation epithermal Au prospects (Rio Liri).

- Western Central Cordillera Belt: porphyry Cu deposits (Cerro Colorado, Cerro Chorcha).

\subsection{QUATERNARY DEPOSITS FORMED BY WEATHERING}

- Lateritic bauxite and iron ore deposits in the Chiriqui-Veraguas Belt.

- Heavy mineral Fe-Ti sands in beach/marine placer deposits in the Gulf of Panama.

- Placer Au deposits in Northern Darien, Darien, Chepo, Coclé, Veraguas and western Azuero-Soná, and many other small deposits.

- Unconfirmed placer Pt deposits in Darien.

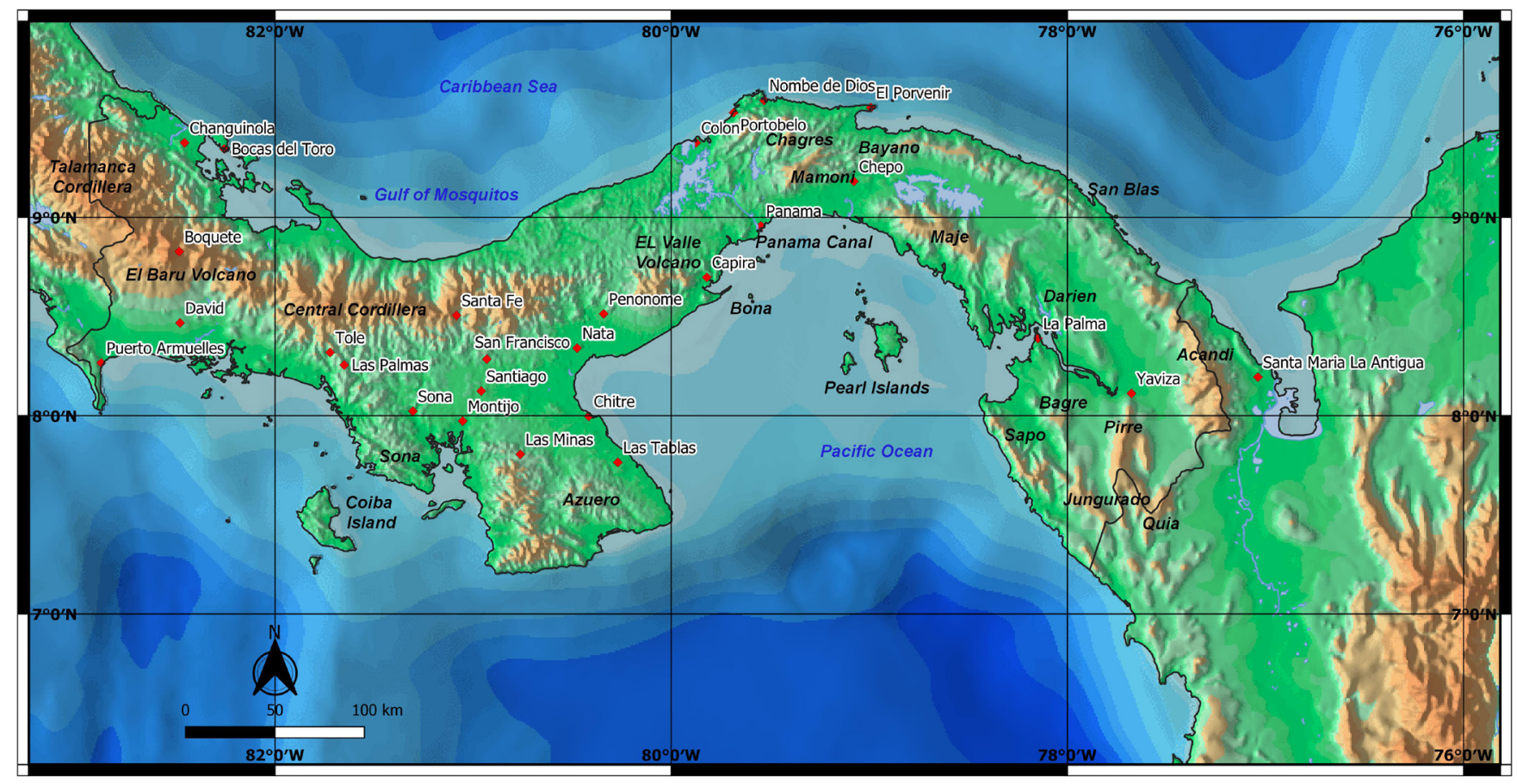

Figure 2 Digital elevation model of Panama showing the names of the main topographic features, cities and towns (S. Redwood). 


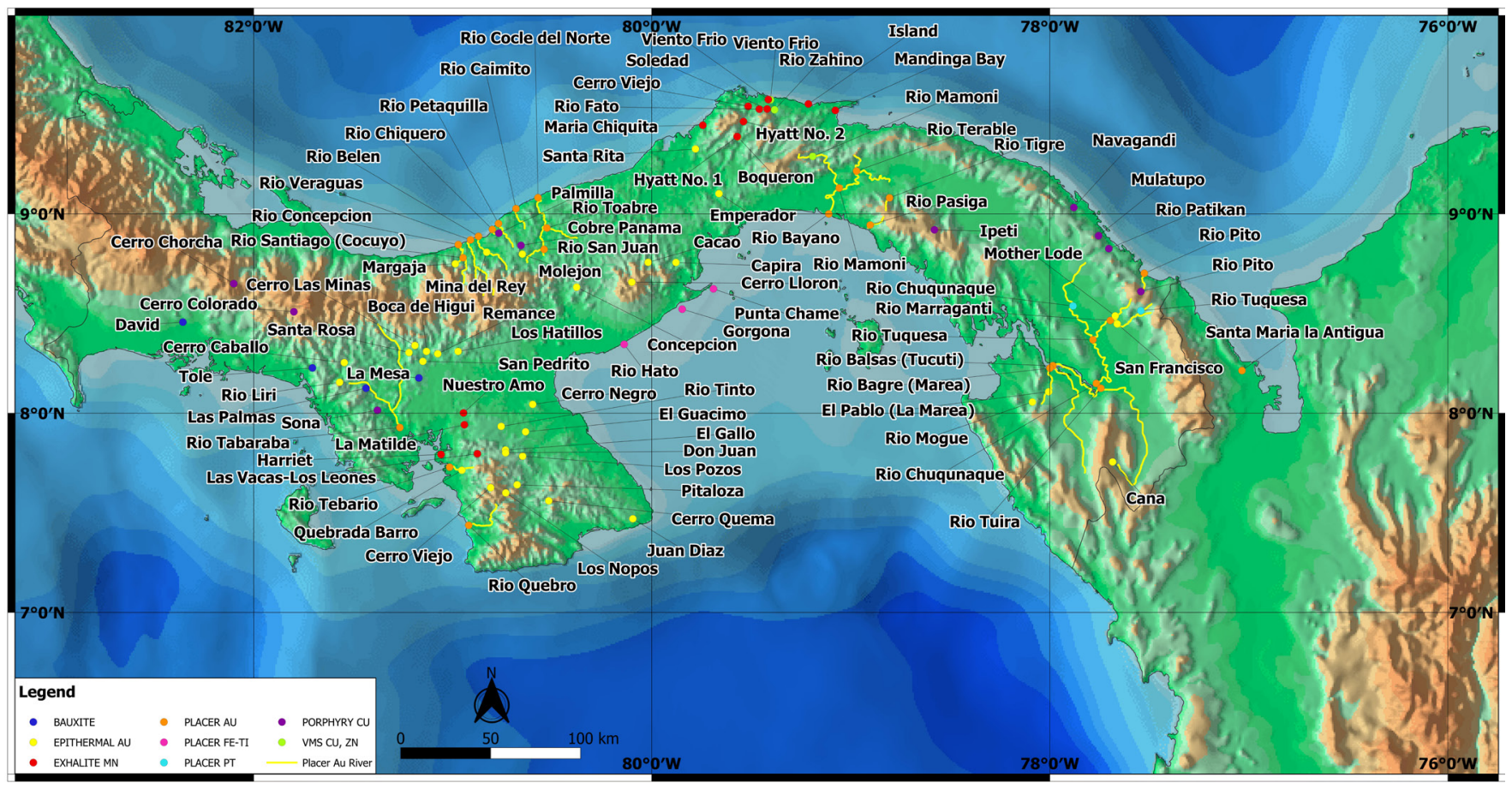

Figure 3 Location map of the principal mineral deposits and prospects of Panama (S. Redwood).

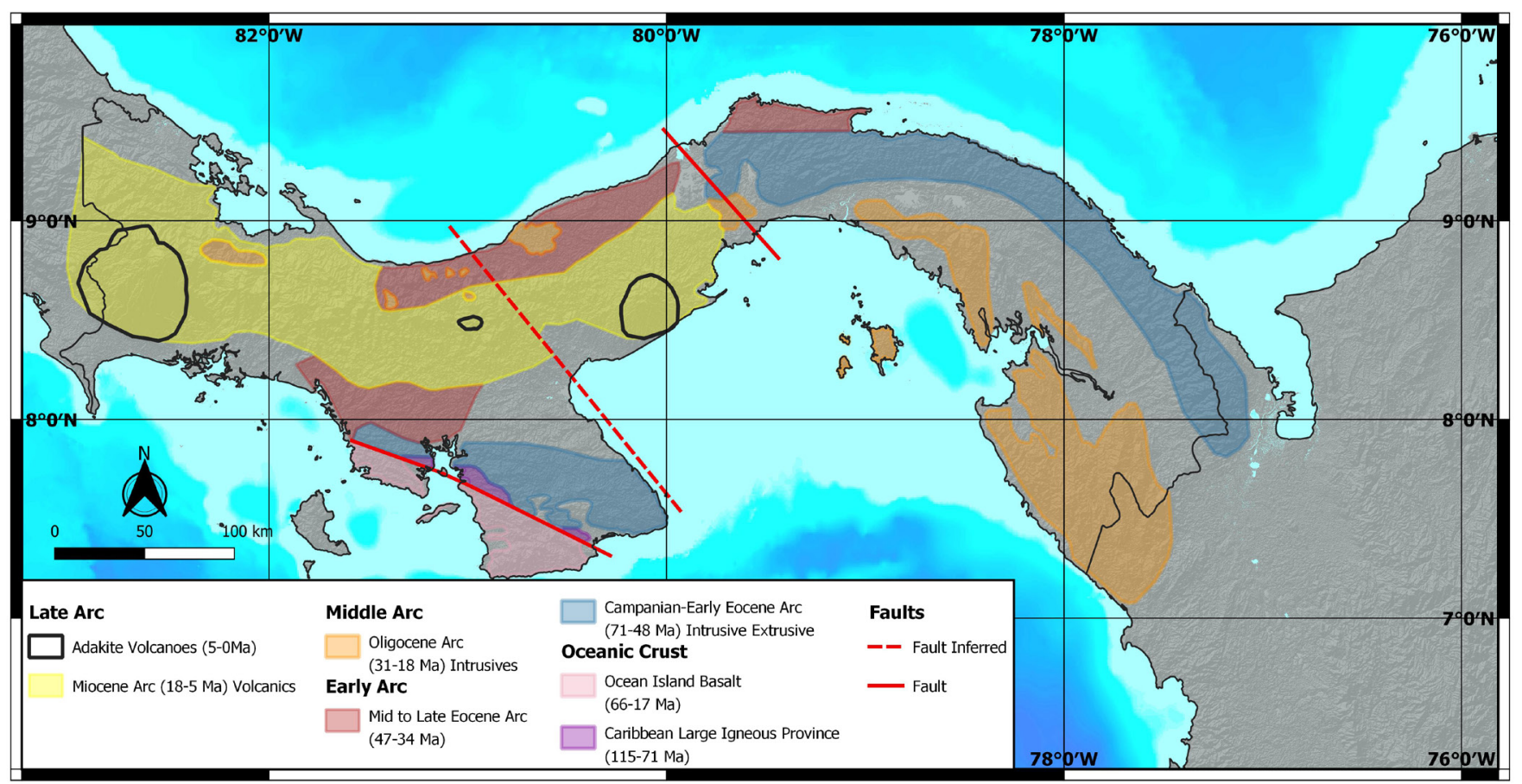

Figure 4 The ages of the igneous rocks of Panama which comprise accreted oceanic terranes and volcanic arcs (modified after Lissinna, 2005; Wegener et al., 2011; Montes et al., 2012a; Corral et al., 2012, 2016; Buchs et al., 2019b; Perelló et al., 2020). 
Table 1. List of the porphyry copper deposits and prospects of Panama.
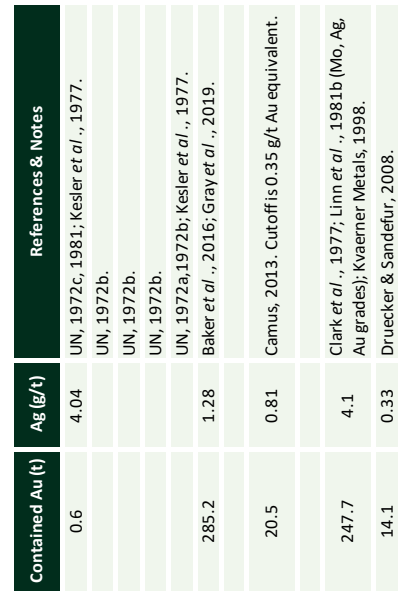

爱

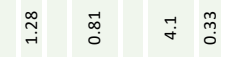

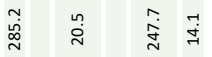

㠃

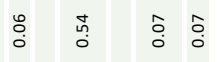

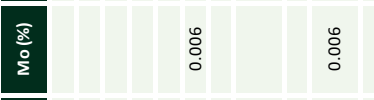

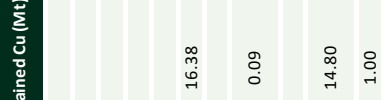

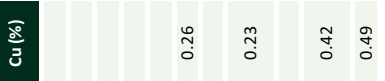

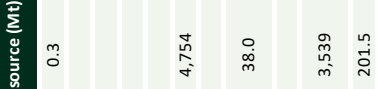

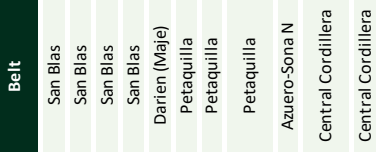

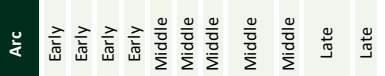

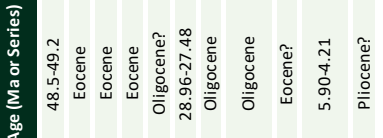

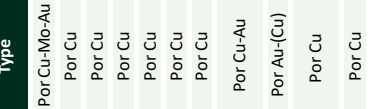

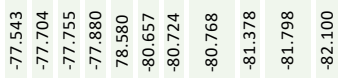

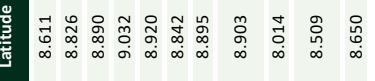

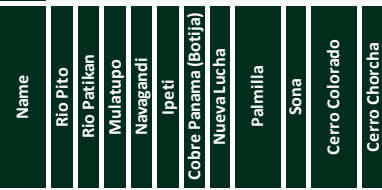

Notes: 1) Abbreviations: Por, porphyry; 2) Coordinates in decimal latitude and longitude, datum wGS84; 3) The coordinates have low accuracy for older prospects; 4) Resource is the total of measured, indicated and inferred; 5) Listed from east to west. 
Table 2. List of the epithermal gold deposits and prospects of Panama.

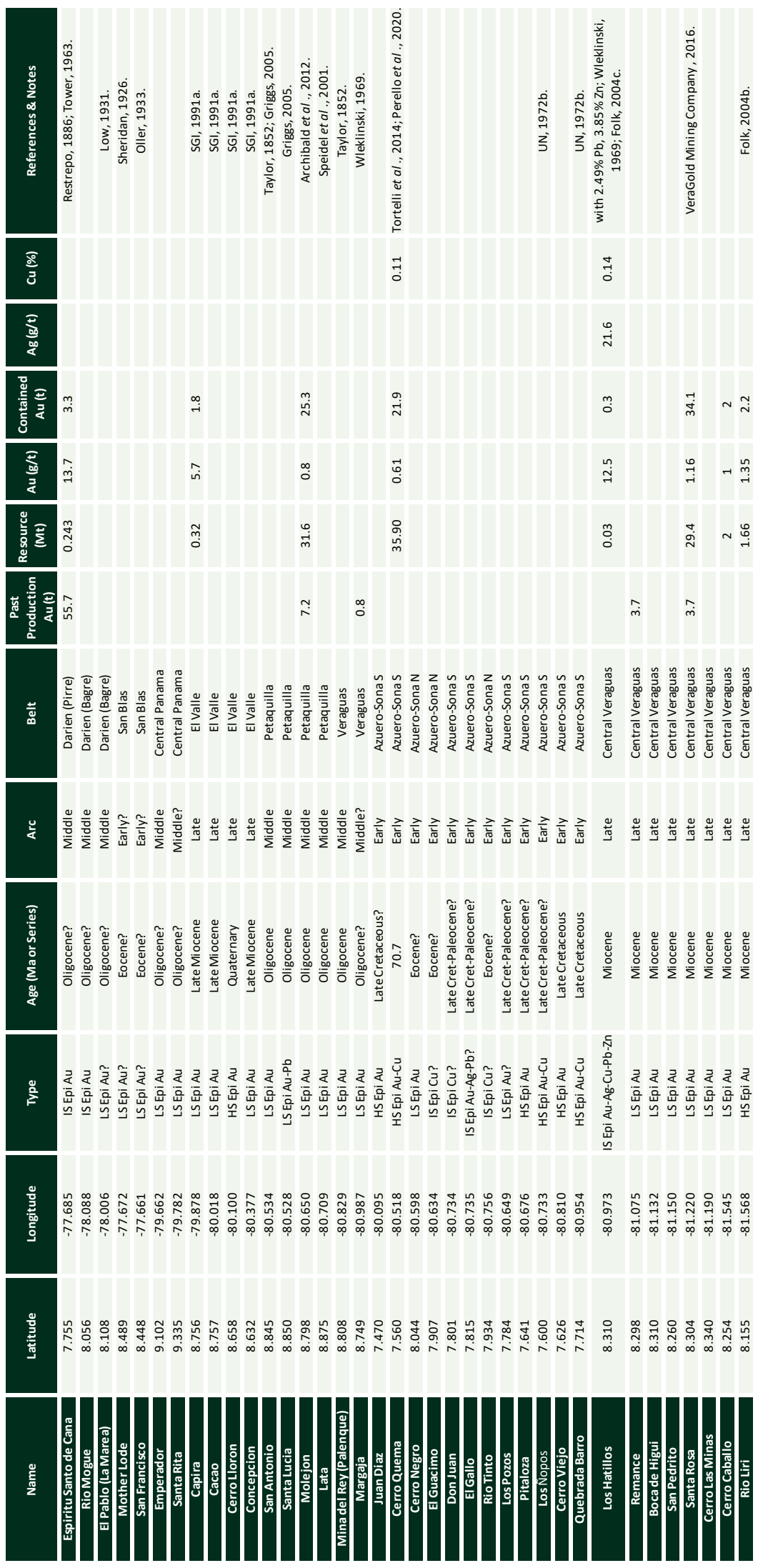

Notes: 1) Abbreviations: Epi, epithermal. LS, low sulphidation. IS, intermediate sulphidation. HS, high sulphidation; 2) Coordinates in decimal latitude and longitude, datum WGS84; 3) The coordinates may have low accuracy for historical mines and older prospects; 4) The resource is total of measured, indicated and inferred; 5) Listed from east to west. 
Table 3 List of the manganese, VMS, bauxite and laterite deposits and prospects of Panama.
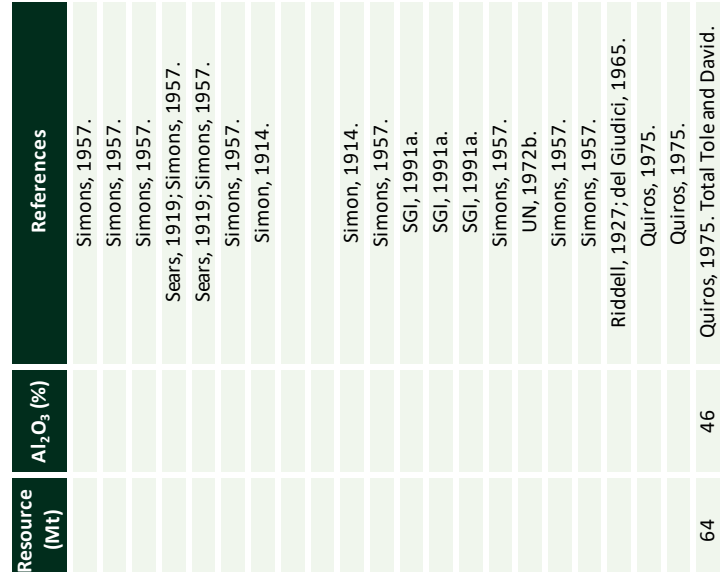

ผู่

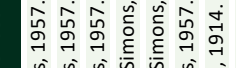

vìn

空岕

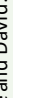
(1)

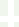
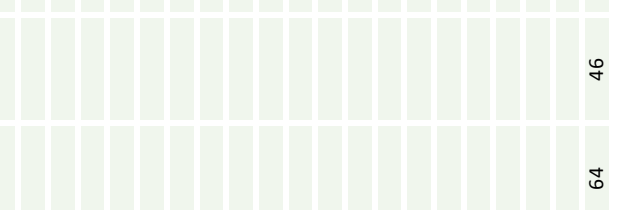

$\stackrel{8}{i n} \quad \stackrel{8}{n}$

吾

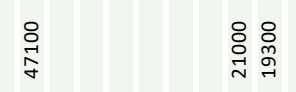

产

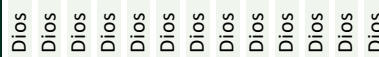

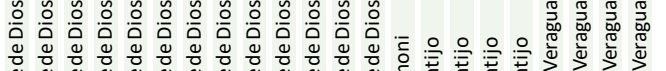

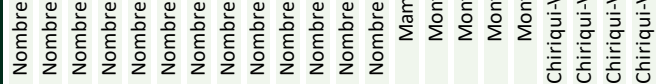

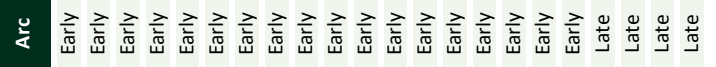

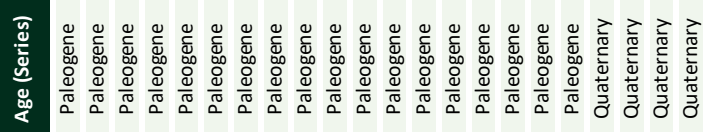

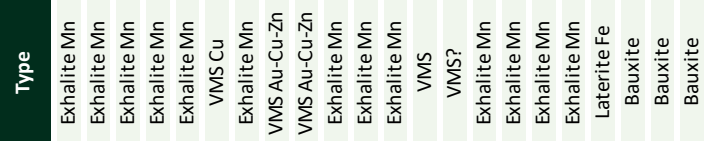

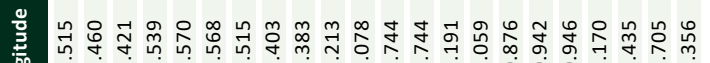

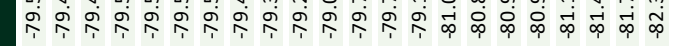

㟒

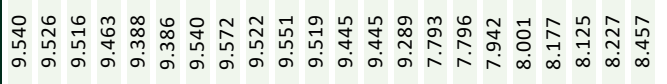

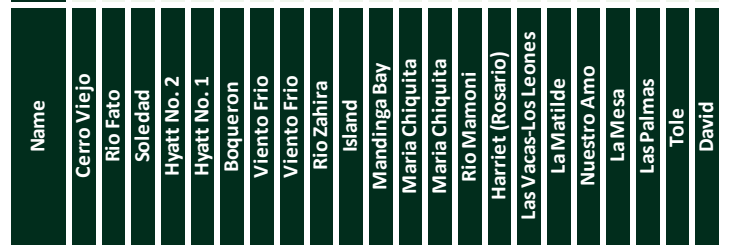

Notes: 1) Abbreviations: VMS, volcanogenic massive sulphide stockwork or occurrence; 2) Coordinates in decimal latitude and longitude, datum WGS84; 3) The coordinates have low accuracy for older prospects; 4) Resource is total of measured, indicated and inferred; 5) Listed from east to west. 
Table 4 List of the placer deposits and prospects of $\mathrm{Au}, \mathrm{Pt}(?)$ and Fe-Ti of Panama.
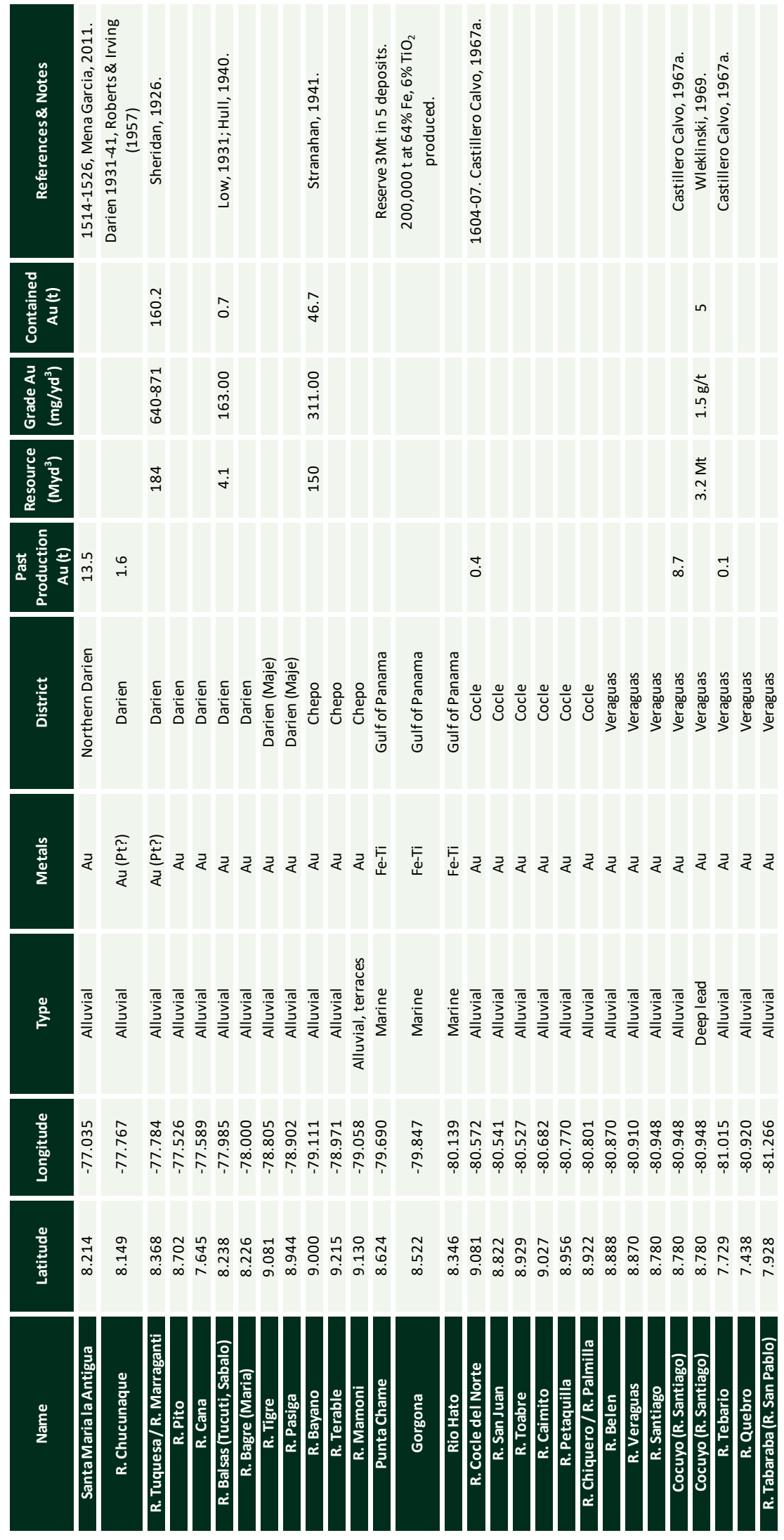

Notes: 1) Coordinates in decimal latitude and longitude, datum WGS84; 2) The coordinates are for the river or tributary-mouth; 3) Listed from east to west. 


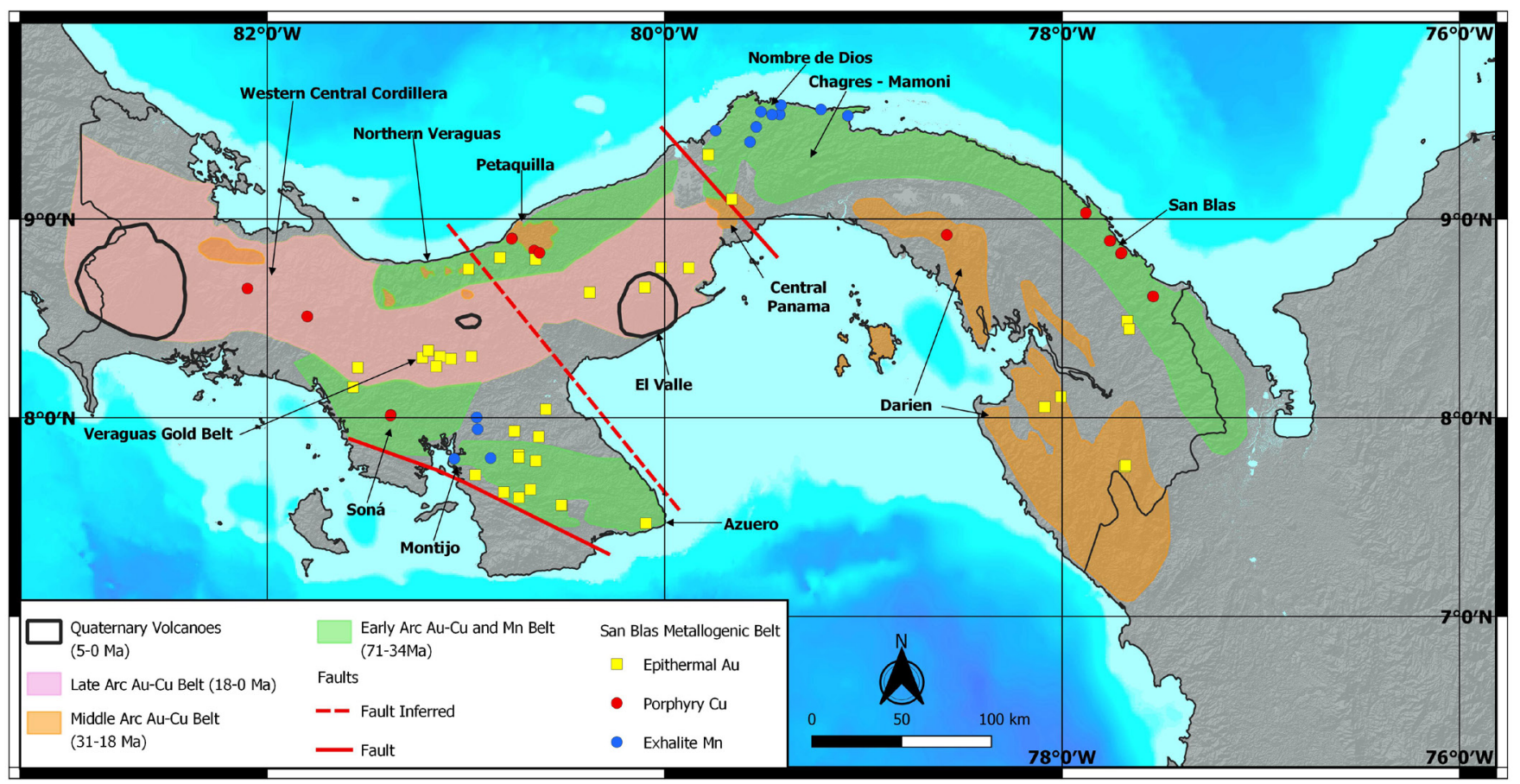

Figure 5 Map of the metallogenic belts of Panama (S. Redwood).

\section{Early Arc: Campanian - Paleogene exhalative deposits}

\subsection{NOMBRE DE DIOS}

Exhalite manganese deposits and VMS style mineralization of $\mathrm{Au}, \mathrm{Ag}, \mathrm{Cu}, \mathrm{Pb}$ and $\mathrm{Zn}$ occur in the Nombre de Dios belt from west of Portobello to San Blas, and south to the River Boqueron in a belt trending $75 \mathrm{~km} \mathrm{E-W}$ by $20 \mathrm{~km}$ wide. The manganese deposits are hydrothermal exhalites which were formed by sea floor precipitation and/ or sub-sea floor replacement by $\mathrm{Si}-\mathrm{Mn}$ oxides in submarine sedimentary and volcanic rocks. The setting is the late Cretaceous-Paleogene Early Arc.

\subsubsection{NOMBRE DE DIOS - VIENTO FRÍO AND BOQUERÓN Mn DEPOSITS}

The main manganese district is located south of Nombre de Dios and Viento Frio in a zone $15 \mathrm{~km}$ E-W and $6 \mathrm{~km}$ wide. The principal deposits are Cerro Viejo (America, Maria-Defense, June and Mariana mines and prospects) in the west, Rio
Fató (Monstroncosa, Mangue de Indio, Panama or Ventura, Machita, Blaque and La Mesa mines and prospects) in the middle and Soledad (Soledad, Concepción and Carano) in the east. The zone extends for about $15 \mathrm{~km} \mathrm{SE}$ along the $025^{\circ}$-trending River Boqueron to Lake Madden to the Hyatt No. 1 and 2 mines. The deposits were described by Simon (1914), Sears (1919) and Simons (1957).

Manganese mining was first carried out in 1871 at Viento Frio, and the mines were worked intermittently until the late $20^{\text {th }}$ century. The Soledad mine, south of Viento Frio, produced about 40,000 tons (36,300 metric tons) of high grade manganese ore grading 53.7\% Mn between 18951902, and the nearby Concepción mine produced 12,000 tons $(10,900$ metric tons) of ore in the same period (Simon, 1914). The Hyatt No. 1 and 2 deposits were discovered in 1915 but produced very little ore, although Sears (1919) estimated potential for 15,000 tons (13,600 metric tons) of high grade ore at each deposit. Most recently, the Caribbean Mining Company mined the Cerro Viejo and Soledad deposits from 1993 for several 
years with planned production of 5,000 metric tons of $45-55 \% \mathrm{Mn}$ per month.

The host rocks were described as sandstone and shale with limestone and tuff beds, which are flat lying near the coast, with steeper dips of 5-10 up to $45^{\circ}$ south going inland (Sears, 1919; Simons, 1957). The limestones were studied by SGI (1991a) which noted dips of $25-80^{\circ} \mathrm{E}$ and association with sandstones and breccias. The DGRM (1991) map assigns them to the late Cretaceous Ocú Formation (limestones and tuffs) of the Changuinola Group, with diorite intrusions. Recent work has shown that the limestones are overlain by pillow lavas and peperites mixed with recrystallized carbonates, interpreted as proto-arc volcanism, which in turn is overlain by pre-Oligocene volcanic arc sequences with andesite lavas and breccias and a volcaniclastic apron of tuffs (D. Buchs, personal communication, 26 September 2019).

Mineralization consists of flat-lying beds, veins and abundant residual boulders of jasper, chert, manganiferous jasper and cherty manganese silicate in saprolitic clay, generally on hill tops (Simons, 1957). The jasper and chert form replacements of sedimentary rocks and tuffs to give stratiform deposits, as well as structurally controlled veins. Some of the replacement textures may be mixing textures of sea-floor exhalites. The jasper is mineralized by hard $\mathrm{Mn}$ oxides (psilomelane - $\mathrm{MnO}$ ) or Mn silicates (braunite $-\mathrm{Mn}_{6}\left(\mathrm{SiO}_{4}\right) \mathrm{O}_{8}$, and rhodonite $-\mathrm{MnSiO}_{3}$ ) mixed with the jasper, which were probably deposited at the same time. The jasper is also cut by veins of $\mathrm{Mn}$ oxides and silicates, as well as quartz and chalcedony veins, indicating multiple pulses of fluid. The silicates weather to soft $\mathrm{Mn}$ oxides (pyrolusite $-\mathrm{MnO}_{2}$ ) on fractures and rinds. Piemontite $\left(\left(\mathrm{Ca}_{2}\right)\left(\mathrm{Al}_{2} \mathrm{Mn}\right)\left(\mathrm{Si}_{2} \mathrm{O}_{7}\right)\left(\mathrm{SiO}_{4}\right)\right.$ $\mathrm{O}(\mathrm{OH}))$ and $\mathrm{Mn}$ carbonate were also recorded (Simon, 1914,1957).

\subsubsection{MANDINGA BAY Mn DEPOSITS}

The only other manganese deposits to have been mined in Panama are at Mandinga Bay at the western end of the Gulf of San Blas, about $40 \mathrm{~km}$ west of the Soledad deposit. They were mined in
1916-1919 and produced 21,310 long tons with $25-30 \% \mathrm{Mn}$ and 40-50\% silica (Simons, 1957). The regional geology is shown as the Cretaceous Playa Venado Formation of basalts and pillow basalts (DGRM, 1991). Mineralization occurs in five deposits over a distance of about $1,600 \mathrm{~m}$ on a NNE-trending ridge near the mouth of the River Nabagana. The host rocks are shale or mudstone with deep saprolitic clay weathering, and $\mathrm{Mn}$ is associated with red and yellow jasper replaced by $\mathrm{Mn}$ silicates (bementite $-\mathrm{Mn}_{7} \mathrm{Si}_{6} \mathrm{O}_{15}(\mathrm{OH})_{8}$ and neotocite $\left.-(\mathrm{Mn}, \mathrm{Fe}, \mathrm{Mg}) \mathrm{SiO}_{3} \mathrm{H}_{2} \mathrm{O}\right)$ and hard Mn oxide (psilomelane), and is weathered to soft oxides (Simons, 1957).

The Island deposit occurs on the coast between the Mandinga Bay and Nombre de Dios-Viento Frio deposits. It is located on a small island about $30 \mathrm{~km}$ east of Nombre de Dios and produced 23,000 tons (20,999 metric tons) of manganese ore in the 1895-1902 period (Simon, 1914).

\subsubsection{BOQUERON VMS CU PROSPECT}

Volcanogenic massive sulphide (VMS) copper mineralization occurs in the Boqueron belt at the Hyatt No. 2 mine, where late stage malachite, calcite and specular hematite were described cross-cutting manganese (Simons, 1957). A grab sample of float of copper sulphides (chalcocite) and oxides (malachite, azurite) ran 7.10\% Cu, 7.2 g/t Ag and 0.05 g/t Au (SGI, 1991a). SGI(1991a) gave an estimated resource of 900,000 metric tons of $4.8 \% \mathrm{Cu}$ associated with the manganese mineralization, although the basis for this estimate is not given and it is more likely to indicate the potential resource.

\subsubsection{VIENTO FRÍO VMS Au-Cu-Zn PROSPECT}

Two zones of stockwork Au-Cu-Zn mineralization occur near Viento Frio and are interpreted to be stockwork feeder zones of Au-rich $\mathrm{Cu}-\mathrm{Zn}$ volcanic hosted massive sulphide deposits.

The first zone at Viento Frio was discovered in 1999 in a road cutting by Rayrock Resources Inc. (Glamis Gold Ltd. from 1999) and drilled in the 
same year. A second zone at Rio Zahino, $6.5 \mathrm{~km}$ southeast, was discovered later by float sampling and drilled in 2001. Rayrock drilled a total of $1,710 \mathrm{~m}$ in 24 holes. Glamis reported a resource of 2.1 Mt at $1.7 \mathrm{~g} / \mathrm{t} \mathrm{Au}(3.57 \mathrm{t} \mathrm{Au})$ for Viento Frio. The project was later acquired by Bellhaven and explored by Western Troy Capital Resources in 2007, with trenching results of $38 \mathrm{~m}$ at $0.79 \mathrm{~g} / \mathrm{t}$ $\mathrm{Au}$ and $38 \mathrm{~m}$ at $0.95 \mathrm{~g} / \mathrm{t} \mathrm{Au}$.

The geology comprises well bedded, fine grained sediments of the late Cretaceous Ocú Formation interbedded with chert, basalt and shale, and cut by feldspar porphyry sills or dykes. Alteration of the sediments is silicification and sericite alteration, with brecciation and stockwork veining with barite, calcite, quartz, coarse pyrite, sphalerite and supergene chalcocite, while the basalts have calcite-zeolite veinlets and are barren. Rock chip sampling defined a Au anomaly of $2 \mathrm{~g} / \mathrm{t}$ over an area of 1,000 $\mathrm{m} \mathrm{NNW}$ by 150-250 $\mathrm{m}$ at Viento Frio. Drilling at Viento Frio returned $6 \mathrm{~m}$ at 1.28 $\mathrm{g} / \mathrm{t} \mathrm{Au}$ and $30.6 \mathrm{~g} / \mathrm{t} \mathrm{Ag}$ with $\mathrm{Zn}, \mathrm{Cu}$ and $\mathrm{Ba}$, while Rio Zahino gave $9.1 \mathrm{~m}$ at $1.53 \mathrm{~g} / \mathrm{t} \mathrm{Au}, 19.8 \mathrm{~m}$ at $0.56 \% \mathrm{Zn}, 50.3 \mathrm{~m}$ at $0.24 \% \mathrm{Zn}$, and $18.3 \mathrm{~m}$ at $0.55 \% \mathrm{Cu}$ and $0.1 \mathrm{~g} / \mathrm{t} \mathrm{Au}$. The geochemical association is $\mathrm{Au}-\mathrm{Cu}-\mathrm{Zn}-\mathrm{Ba}-\mathrm{Mn}-(\mathrm{Ag}-\mathrm{As})$.

\subsubsection{MARIA CHIQUITA Mn AND VMS PROSPECT}

Between Maria Chiquita and the River Cuango, $16 \mathrm{~km}$ southwest of Portobello, a $5 \mathrm{~km}$ by $3 \mathrm{~km}$ zone of manganese associated with jasper and chert in sedimentary rocks overlying basalts was described by SGI (1991a). Road cuts near Maria Chiquita are in brecciated volcanic rock with pyrite. Stream sediment samples gave an anomaly of 2-260 ppm As, and float samples gave 0.11-0.17 $\mathrm{g} / \mathrm{t} \mathrm{Au}$ and $11 \mathrm{~g} / \mathrm{t} \mathrm{Ag}$.

\subsection{CHAGRES-MAMONÍ ARC}

\subsubsection{RIO MAMONÍ VMS STOCKWORK Au-Cu-Pb PROSPECT}

Stockwork sulphide mineralization in a $5 \mathrm{~km} \mathrm{E-W}$ zone associated with alluvial gold in the River Mamoni was evaluated by SGI (1991a). Mineral- ization occurs in basalts intercalated with shales, cherts and limestones at the contact with a tonalitic intrusion. Some sedimentary beds contain abundant pyrite and pyrrhotite, and there are manganese-rich horizons. The stockworks are zones of silicification with quartz veinlets containing pyrite, chalcopyrite, galena, sulfosalts and barite, with up to $0.35 \mathrm{~g} / \mathrm{t}$ Au in grab samples, in basalts near the intrusive contact and in the intrusion. The mineralization was interpreted as a stockwork zone related to a VMS system (SGI, 1991a). The host rocks are the Chagres-Bayano arc described as late Cretaceous to Paleocene Volcaniclastic Basement and Utive-Mamoni Plutonic Basement (Montes et al., 2011, 2012b).

\subsection{MONTIJO (AZUERO) Mn PROSPECTS}

Several manganese prospects occur in a belt between Atalaya and the Gulf of Montijo that is about $30 \mathrm{~km} \mathrm{NE}$ by $20 \mathrm{~km}$ wide. It was discovered by the Panama Corporation in 1927 which estimated potential for several million metric tons of manganese ore at Matilde and several hundred thousand metric tons at Bahia Honda (Riddell, 1927). Three of the prospects were described by Simons (1957) who visited in 1942. Two other prospects were explored by the DGRM and the UN program in 1964-1972 with 5 shallow drill holes (UN, 1972a).

The regional geology is mapped as the Cretaceous Ocú Formation (limestones and tuffs) in the south and Oligocene Macaracas Formation (tuffs and tuffaceous sandstones) in the central and northern parts (DGRM, 1991), while radiometric dating shows the zone to be in the Paleocene to Eocene Early Arc (Lissinna, 2005; Cardona et al., 2018). The Harriet (Rosario) prospect, located on the east side of the Gulf of Montijo, has N-striking lenses of Mn oxide (psilomelane), Mn silicate and limonite in jasper and weathered andesite. The La Matilde prospect, located about $7 \mathrm{~km} \mathrm{NE}$ of Ponuga, is a zone about 1,000 m E-W with Mn oxide boulders (psilomelane), a thin manganiferous jasper bed, Mn silicates, and Mn oxide veinlets in jasper hosted by shale dipping $30^{\circ} \mathrm{N}$ that overlies 
basaltic and andesitic agglomerates, and rhyolitic tuffs. The Nuestro Amo prospect, located $5 \mathrm{~km}$ SW of Atalaya, has Mn silicate and oxides in a N-S body dipping $35^{\circ} \mathrm{W}$ hosted by andesites (Simons, 1957). The Las Vacas-Los Leones prospects, $12 \mathrm{~km}$ west of Las Minas and $20 \mathrm{~km}$ east of the Harriet prospect, have small lenses of pyrolusite and psilomelane in intermediate to basic lavas and tuffs (UN, 1972a). Riddell (1927) described manganese showings in float from several other prospects in the Soná-Azuero peninsulas and near Santiago, which potentially extend the belt considerably; the most interesting being a large body of manganese in limestone between Pesé and Ocu.

The style of mineralization of veins and beds of Mn silicates and Mn oxides associated with jasper in shales and volcanic rock is similar to that of the Nombre de Dios-Viento Frio deposits, as is the age of the host rocks. The Azuero prospects have more $\mathrm{Fe}$ and are interpreted to have a similar orgin as exhalative Si-Fe-Mn oxides.

\section{Early Arc: Campanian - Eocene porphyry and epithermal deposits}

\subsection{GAMPANIAN - EOGENE ARG}

The Early Arc of volcanic (basaltic andesite to rhyolite) and plutonic (gabbro-diorite to tonalite) rocks forms the San Blas mountains on the northern side of eastern Panama, and the Chagres-Mamoni mountains in eastern central Panama, and has been dated at 65-39 Ma in the Paleocene-Eocene (Lissinna, 2005; Wegner et al., 2011; Montes et al., 2012a, 2012b; Cardona et al., 2018; Barbosa-Espitia et al., 2019). The arc has porphyry $\mathrm{Cu}$ mineralization in the eastern part at the Rio Pito and other prospects. There are no known porphyry-epithermal deposits in western San Blas or the Chagres-Mamoni belts.

The Early Arc continues in western Panama in the Azuero and Soná peninsulas with a $200 \mathrm{~km}$ left lateral offset. In Azuero the Early Arc can be subdivided into a Campanian to early Eocene arc (71-48 Ma) in the southern part, and a middle to late Eocene arc (47-34 Ma) in the northern part (Lissinna, 2005). It developed on the protoarc Azuero Primitive Volcanic Arc of late Campanian to Maastrichtian age which has a basement of oceanic basalt of the Azuero Igneous Basement of Aptian to early Santonian age, part of the Caribbean Large Igneous Province (Buchs et al., 2011 b; Corral et al., 2012). The older part of the arc contains several porphyry lithocaps with high sulphidation epithermal Au-Cu mineralization at Cerro Quema deposit and other prospects. The younger, northern part of the arc has epithermal $\mathrm{Au}$ and $\mathrm{Cu}$ deposits and a porphyry Au prospect at Soná.

The late Cretaceous to Eocene arc is inferred to continue west-northwest of the Soná peninsula and is buried beneath the Oligocene-Recent volcanic rocks of the Central Cordillera, based on the presence of the back arc belt on the north side of the cordillera in Bocas del Toro. This comprises volcaniclastic rocks and pelagic limestones of the Changuinola Formation (Campanian-Maastrichtian; Fisher and Pessango, 1965) and volcaniclastic turbidites, debris flow deposits, lavas and tuffs of the Tuis Formation (Paleocene-lower Eocene), which are overlain to the north at lower elevations and in the offshore Limon Basin by middle Eocene to Quaternary back arc turbiditic and volcaniclastic sediments and limestones (Mende, 2001; Brandes et al., 2007). Together these were deformed in a NE-verging fold and thrust belt. There is no known mineralization in the back arc of the Early Arc in western Panama.

\subsection{EASTERN SAN BLAS PORPHYRY BELT}

A United Nations regional stream sediment survey of the eastern part of San Blas in 1969-1971 found multiple $\mathrm{Cu}, \mathrm{Mo}$ and $\mathrm{Zn}$ anomalies with values of up to $1,200 \mathrm{ppm}$ copper, 28 ppm molybdenum, $540 \mathrm{ppm}$ zinc and $30 \mathrm{ppm}$ lead and porphyry $\mathrm{Cu}-\mathrm{Mo}$ prospects in a NW-trending belt $75 \mathrm{~km}$ long. The porphyries are named, from NW to SE: Navagandi, Mulatupo, Rio Patikan and Rio Pito.

Rio Pito was the strongest anomaly with $\mathrm{Cu}$ in soil values of between $<300 \mathrm{ppm}$ to over 1,300 
ppm in an area of at least $10 \mathrm{~km}^{2}$, and a follow up exploration program was carried out in 19701972 (UN, 1972a, 1972b, 1972c, 1981; Nelson, 1995). Navagandi, Mulatupo and Rio Patikan were described by UN (1972a, 1972b) but no follow up was carried out. Rio Pito is close to the Acandi porphyry Cu prospect in Colombia which was discovered a few years later by the UN and INGEOMINAS in 1975-1976. Several companies carried out reconnaissance exploration of the Rio Pito district in the 1980s-2000s, but none have drilled.

\subsubsection{RIO PITO PORPHYRT Cu-Mo-Au PROSPECT}

The Rio Pito porphyry Cu-Mo-Au prospect is located in the eastern part of San Blas close to the Colombian border. It was described by several United Nations reports (UN, 1972a, 1972b, 1972c, 1981), Kesler et al. (1977) and Nelson (1995). It was discovered by a stream sediment survey in 1969-1971 with follow up exploration program including shallow drilling in 1970-1972 (UN, 1972a, 1972b, 1972c, 1981).

Rio Pito is a porphyry district with stream sediment anomalies from UN sampling of up to 1,200 ppm Cu, 28 ppm Mo and 540 ppm Zn, and clusters of rock anomalies of up to 2,400 ppm $\mathrm{Cu}$ with $\mathrm{Mo}, \mathrm{Pb}$ and $\mathrm{Zn}$. These occur over a length of about $14 \mathrm{~km}$ NW-SE to the Colombian border and a width of 4-6 km. Gold and silver were assayed in rocks but not in stream sediments or soils. The district is contiguous with the Acandi (Colombia) porphyry $\mathrm{Cu}$ prospect to the SE making it at least $20 \mathrm{~km}$ long. The individual deposits in the Rio Pito district are, from NW to SE: Rio Nalundí, Rio Pito, Rio Parraganti and Rio Caña Blanca or Tuquesa (Figure 6).

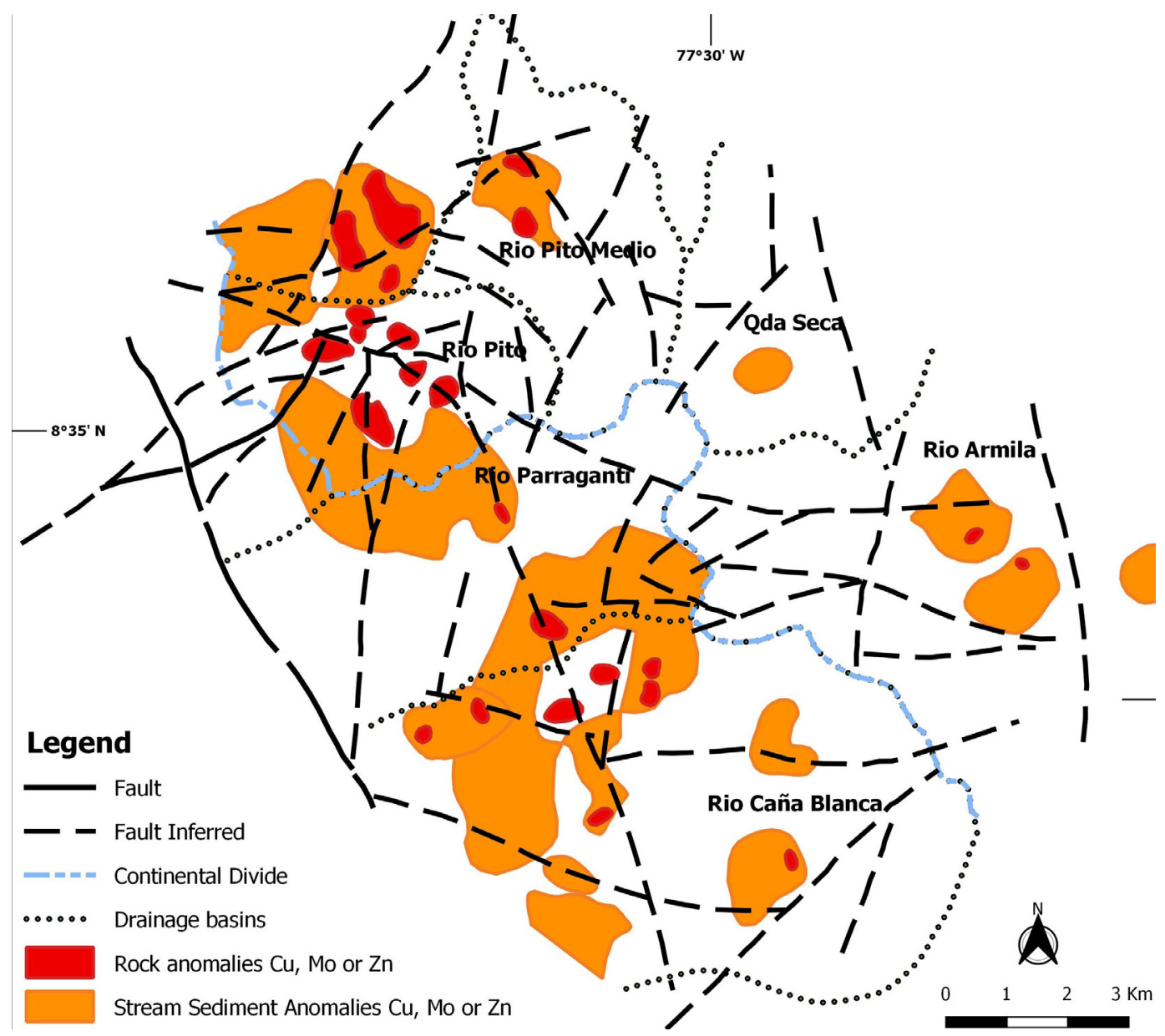

Figure 6 Geochemical anomalies of the Rio Pito district with drainages, geology and faults (after UN, 1972c). 
The host rocks at Rio Pito are the Rio Pito batholith of tonalite, granodiorite and quartz diorite, dacite and rhyodacite porphyry, and Upper Cretaceous(?) basalts and andesites (Figure 7). These are in faulted contact with a basaltic volcanic complex of Eocene age south of the NW striking San Blas Fault. Kesler et al. (1977) obtained K-Ar dates for the mineralized quartz porphyry of 49.2 and 48.5 Ma. These ages are in agreement with recent $\mathrm{U}-\mathrm{Pb}$ zircon dating from the San Blas Mountains west of Rio Pito from plutons of gabbro to granite composition with ages between 59.0 $\pm 1.9 \mathrm{Ma}$ to $49.7 \pm 1.6 \mathrm{Ma}$ (late Paleocene to lower Eocene) (Montes et al., 2015).

Rio Pito itself has seven zones of mineralization in a circle $2.7 \mathrm{~km} \mathrm{E-W}$ by $1.8 \mathrm{~km}$ with a barren core, hosted by andesite, batholith and porphyry (Figure 7). Mineralization consists of pyrite, mag- netite, chalcopyrite and molybdenite with minor gold and silver and a halo of pyrite, sphalerite and galena. There is a gold-bearing breccia pipe at the Palacios sector in which UN drilled 2 holes for 302 $\mathrm{m}$ with the best intercept of $16 \mathrm{~m}$ grading 0.23 $0.92 \% \mathrm{Cu}$ and 0.2-0.6 g/t Au. UN made a historical resource estimate of 297,300 t grading 2.12 $\mathrm{g} / \mathrm{t} \mathrm{Au}$ and $4.04 \mathrm{~g} / \mathrm{t} \mathrm{Ag}$ based on trenches and drilling. Gold-copper mineralization at Palacios is accompanied by quartz, sericite, biotite, magnetite and pyrite which suggests phyllic overprinting potassic alteration (UN, 1981; Nelson, 1995)

UN drilled another 5 holes for $1,290 \mathrm{~m}$ in zones of quartz-sericite alteration. These showed a supergene zone 20-70 m thick, with $\mathrm{Cu}$ up to $1 \%$ and $0.33-0.67 \mathrm{~g} / \mathrm{t} \mathrm{Au}$. The best hypogene intersection was $49.5 \mathrm{~m}$ of $0.21 \% \mathrm{Cu}$ and $0.04-0.17 \mathrm{~g} / \mathrm{t}$ $\mathrm{Au}$ (UN, 1981; Nelson, 1995).

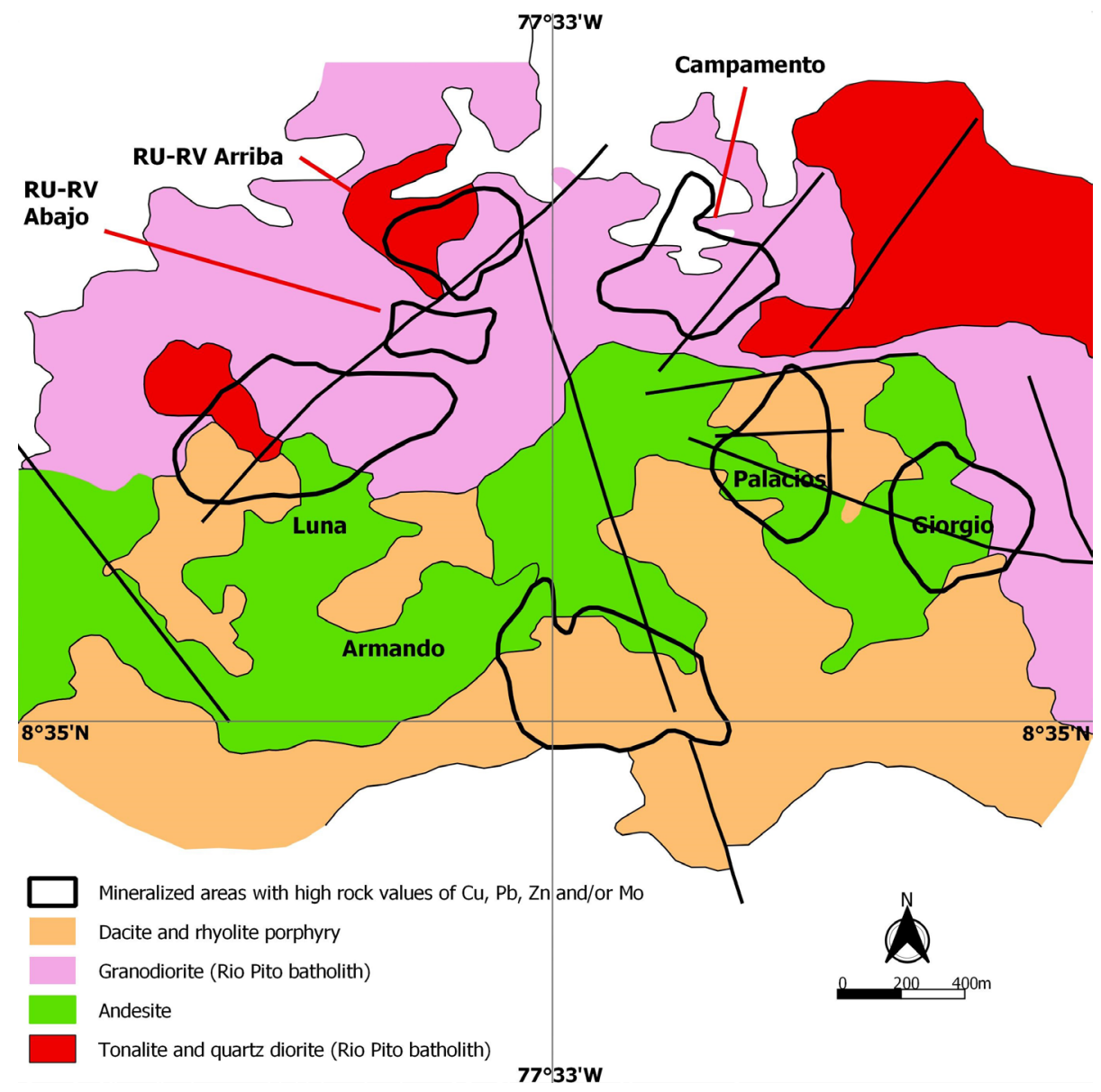




\subsection{WESTERN SAN BLAS AND GHAGRES-MAMONÍ BELT}

The western San Blas and Chagres-Mamoní (or Chagres-Bayano) segments of the arc have no known porphyry-epithermal mineralization: however, they have not been systematically explored for mineral deposits and are considered to be prospective. Several publications show a porphyry copper prospect at Cerro Azul, east of Panama City (e.g. Nelson, 1995; Gray et al., 2010); however, the original description of it, which reported a K-Ar date of $61.58 \mathrm{Ma}$, indicated that the sample was from a diorite to quartz diorite batholith with porphyritic units, but did not describe porphyry-style mineralization (Kesler et al., 1977). The only known mineralization in the Chagres-Mamoni arc is a VMS-style sulphide prospect, described above, which may be the source of placer Au in the Rivers Mamoni and Bayano, and indicates that the arc was submarine.

\subsection{AZUERO-SONÁ EPITHERMAL-PORPHYRY Au-Gu BELT}

\subsubsection{OVERVIEW}

The Early Arc continues in the Azuero and Soná peninsulas, separated from the Chagres-Mamoni arc by a $200 \mathrm{~km}$ left lateral offset. Here the Early Arc can be subdivided into a Campanian to early Eocene arc (71-48 Ma) in the southern part, and a middle to late Eocene arc (47-34 Ma) in the northern part (Lissinna, 2005).

The Campanian to Eocene arc has basement of oceanic basalt of the Azuero Igneous Basement of Aptian to early Santonian age which is overlain by the protoarc Azuero Primitive Volcanic Arc of late Campanian to Maastrichtian age (Buchs et al., 2011b; Corral et al., 2012). To the south there are accreted oceanic seamounts and plateaus of the (Cretaceous?) to Paleogene age Azuero Accretionary Complex which were accreted to the paleo-sub-

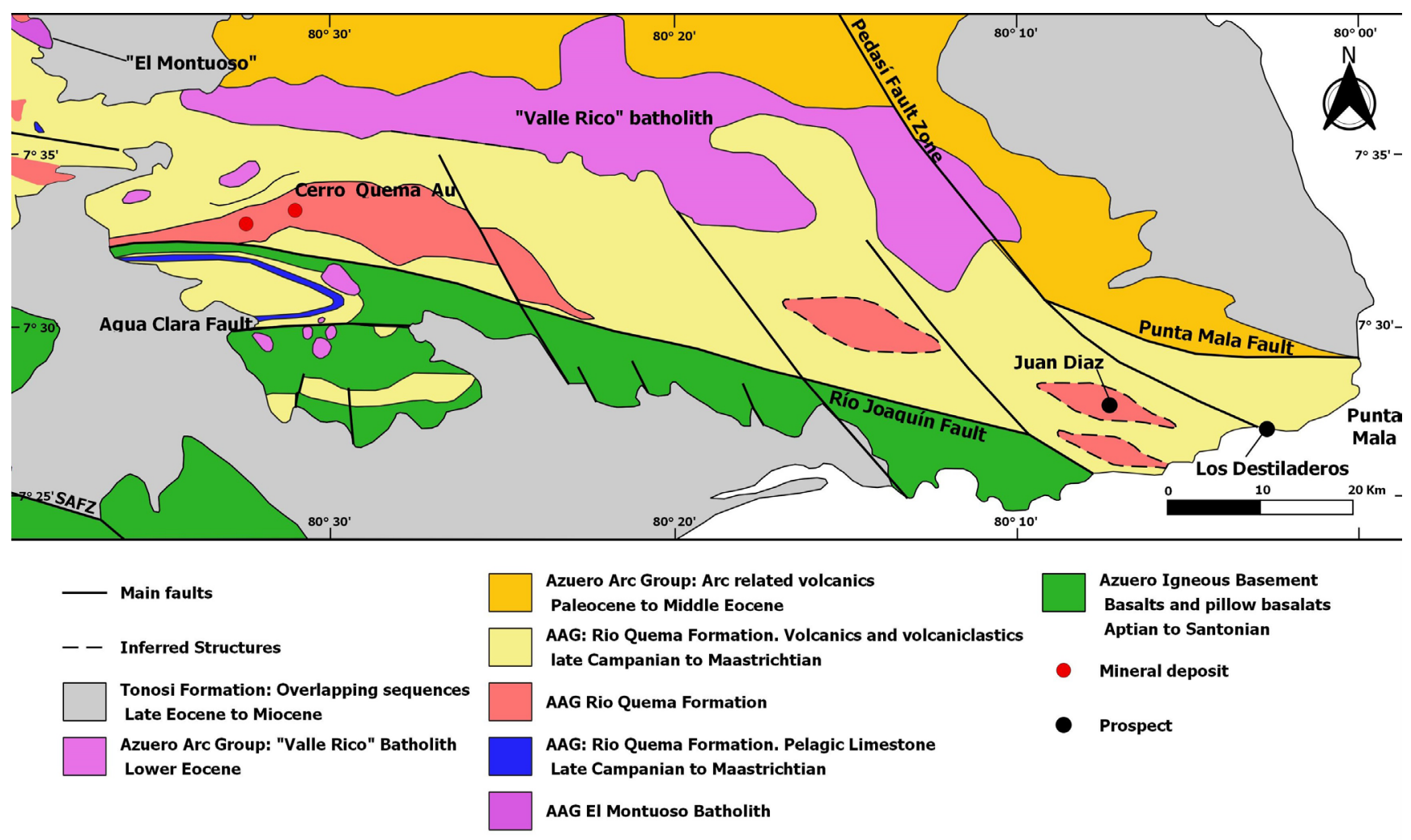

Figure 8 The geology of the eastern part of Campanian to Eocene arc and Au-Cu belt in the southern Azuero peninsula (after Corral et al., 2012). 
duction trench. North of the volcano-sedimentary arc rocks, intermediate to felsic batholiths of late Cretaceous to Eocene age are exposed. There is partial cover by Neogene sediments of the Tonosí Formation (middle Eocene to early Miocene).

The Campanian to early Eocene arc extends for $100 \mathrm{~km}$ in southern Azuero and has several zones of advanced argillic and vuggy silica alteration with high sulphidation epithermal gold-copper mineralization at the Cerro Quema deposit, and other gold-copper prospects such as Juan Diaz, Pitaloza and Cerro Viejo (Figure 8). The belt is a porphyry lithocap environment and is prospective for porphyry copper deposits as well as high sulphidation epithermal gold, and, in fact, porphyry style mineralization occurs at depth at Cerro Quema.

The Cerro Quema deposit and other epithermal prospects occur in topographically high ground up to $920 \mathrm{~m}$ altitude with high relief of almost $800 \mathrm{~m}$, despite the age of the rocks (Figure 10). Cerro Quema is part of a NW-SE striking topographic high that extends across the Azuero Peninsula and contrasts with the much lower topography to the north and south, where broadly similar aged hemipelagic limestone of the Ocu Formation and oceanic plateau basalts are locally unconformably capped by Eocene limestones and turbidites of the Tonosi Formation (Buchs et al. 2011 a). The strike of the topographic high follows the orientation of a major set of faults, the Joaquin Fault Zone (Buchs et al., 201 1b; Corral et al., 2018). These observations indicate relatively recent uplift and tectonism in the fore-arc linked to subduction processes (Buchs et al. 201 lb) or to left lateral strike slip movement along the Azuero Fault and others related to the movement on the Panama microplate / Nazca plate boundary to the south and the collision of the Panama arc with the Northern Andes in the late Miocene (Mann and Kolarsky, 1995; Kolarsky et al., 1995a).

The volcanic arc in the northern parts of the Azuero and Soná peninsulas is of Eocene age (Lissinna, 2005). This area is at a lower elevation than the southern part, with more extensive cover by Neogene sediments. There are several poorly known epithermal $\mathrm{Au}$ and $\mathrm{Cu}$ prospects and old mines which are presumed to be of Eocene age also, including the Cerro Negro Au prospect, El Guácimo Cu deposit, Rio Tinto (Ocú) Cu deposit, the El Gallo $\mathrm{Au}-\mathrm{Ag}-\mathrm{Pb}$ deposit, and a gold porphyry prospect at Soná.

\subsubsection{FUAN DÍAZ HIGH SULPHIDATION EPITHERMAL Au PROSPECT}

The Juan DÍaz high sulphidation epithermal gold prospect is located near Pedasi, $55 \mathrm{~km}$ east of the Cerro Quema deposit at the eastern end of the Azuero Au-Cu belt. The project was explored by Cyprus Minerals in 1990-1994. Advanced argillic alteration of dacitic bedded ash tuffs, agglomerates and flows comprising quartz-dickite-pyrite and quartz-kaolinite-pyrite with silica ledges with alunite is well exposed for $1,300 \mathrm{~m}$ on the beach to the east at Los Destiladeros. Residual quartz occurs as clasts in ferricrete.

\subsubsection{CERRO QUEMA HIGH SULPHIDATION EPITHERMAL Au-Cu DEPOSIT}

The Cerro Quema deposit is a high sulphidation epithermal system which overprints porphyry veining. A gold oxide zone with vuggy silica and advanced argillic alteration overlies a sulphide zone with enargite-chalcopyrite-pyrite and supergene copper enrichment. The geology has been described by Torrey and Keenan (1994), Corral (2013), Corral et al. (2010, 201 1, 2012, 2013, 2016, 2017, 2018), Perelló et al. (2020), and several NI 43-101 reports of which the latest is Tortelli et al. (2014).

Cerro Quema was identified in 1967 by a single sample copper anomaly in a regional stream sediment survey by the United Nations program (UN, 1969). Chalcocite was found in boulders in a stream draining Cerro Quemita but no outcropping mineralization was found. The gold potential was not recognized until 1986, since when it has been explored by several companies. The total (measured, indicated and inferred) oxide resource is $24.6 \mathrm{Mt}$ at $0.71 \mathrm{~g} / \mathrm{t} \mathrm{Au}$ and $0.04 \% \mathrm{Cu}$ plus 11.4 


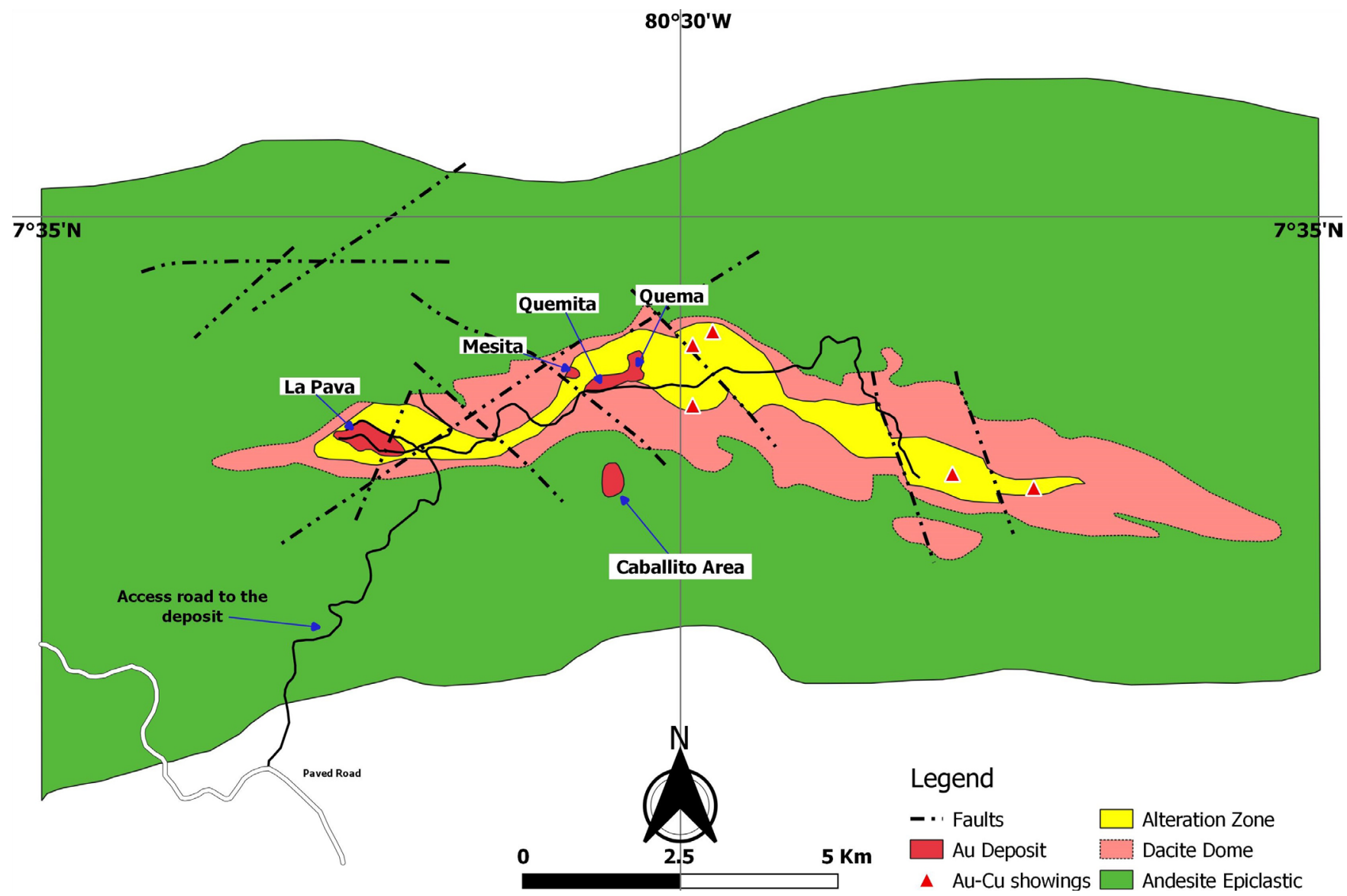

Figure 9 The geology of the Cerro Quema gold deposit (Pershimco).

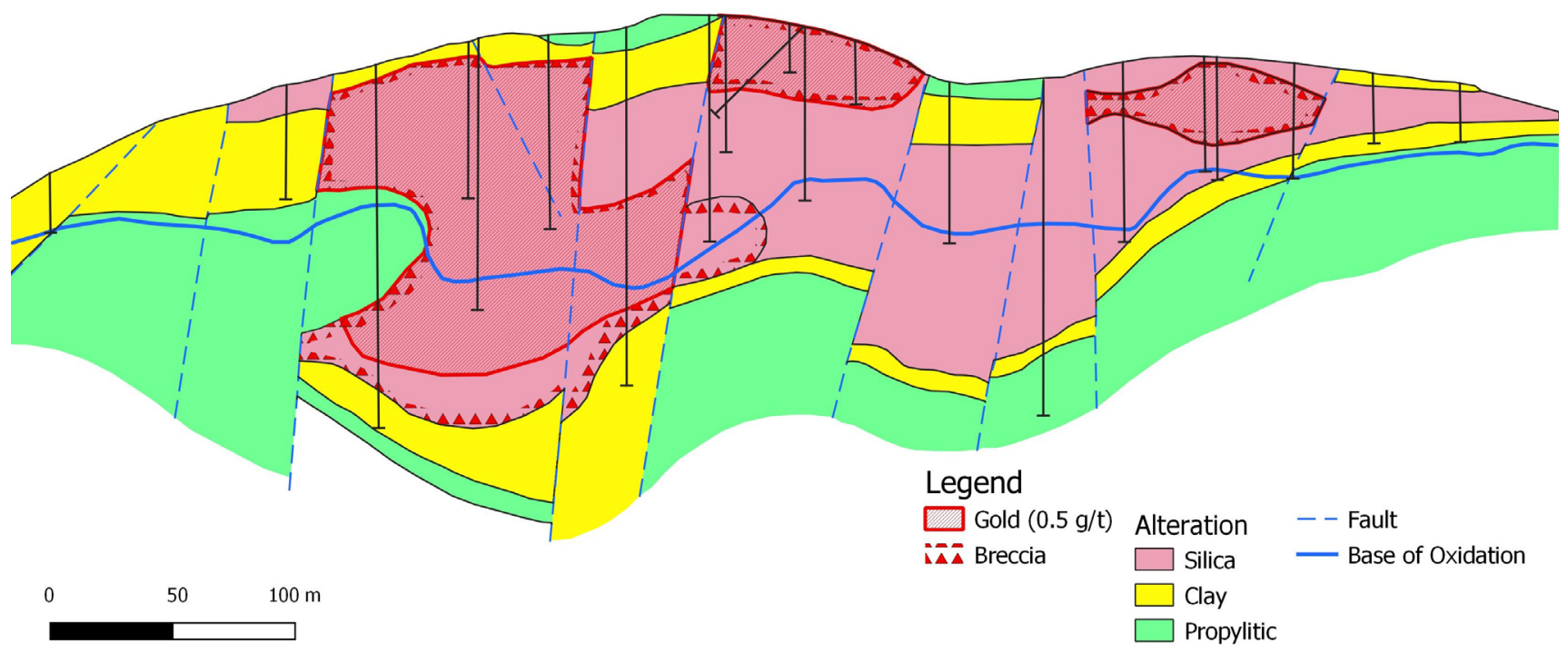

Figure 10 Long section of the La Pava gold deposit (Puritsch et al., 2012). 
Mt at $0.41 \mathrm{~g} / \mathrm{t} \mathrm{Au}$ and $0.31 \% \mathrm{Cu}$ in sulphides, containing a total of $22.10 \mathrm{t} \mathrm{Au}$ and $38,100 \mathrm{t}$ $\mathrm{Cu}$, which occurs in four zones, La Pava, Quema, Quemita and La Mesita (Tortelli et al., 2014). The proven and probable reserves in oxides at La Pava and Quema are $19.71 \mathrm{Mt}$ at $0.77 \mathrm{~g} / \mathrm{t}$ Au containing $15.18 \mathrm{t}$ of gold, with the majority in La Pava (Tortelli et al., 2014). Orla Mining Ltd applied for an environmental license to build a mine in 2016, the outcome of which is still awaited.

At the Caballito (including Idaida) zone southeast of Quemita, an $800 \mathrm{~m}$ by $400 \mathrm{~m}$, NW-trending chargeability anomaly was drilled in 2017-2018 with highlights in the supergene sulphide zone of $147.7 \mathrm{~m}$ at $0.28 \mathrm{~g} / \mathrm{t} \mathrm{Au}$ and $1.25 \% \mathrm{Cu}$ from 42.5 $\mathrm{m}$ in breccia, including $42 \mathrm{~m}$ at $0.36 \mathrm{~g} / \mathrm{t} \mathrm{Au}$ and $3.12 \% \mathrm{Cu}$; and $124.5 \mathrm{~m}$ at $0.47 \mathrm{~g} / \mathrm{t} \mathrm{Au}$ and $1.54 \%$ $\mathrm{Cu}$ from $75.0 \mathrm{~m}$ including $33 \mathrm{~m}$ at $0.49 \mathrm{~g} / \mathrm{t}$ Au and $2.78 \% \mathrm{Cu}$.

Mineralization at Cerro Quema is hosted by a dacite dome complex intruded into fore-arc basin volcano-sedimentary rocks comprising conglomerate, sandstone, mudstone, limestone, turbidites of the Rio Quema Formation which has been dated by biostratigraphy as Upper Campanian to
Maastrichtian (Figure 9; Corral et al., 2012; 2016). It is cut by basaltic to andesitic dykes. Two ages of magmatism have been defined by ${ }^{40} \mathrm{Ar} /{ }^{39} \mathrm{Ar}$ and U-Pb dating (Corral et al., 2012, 2016; Montes et al., 2012a): $67.9 \pm 1.1$ to $65.6 \pm 1.3 \mathrm{Ma}$ (Maastrichtian) for dacite domes in the Río Quema Formation; $67.5 \pm 1.1$ to $65.7 \pm 1.0 \mathrm{Ma}$ for the El Montuoso batholith; and 49.2 $\pm 0.9 \mathrm{Ma}$ (early Eocene) for the Valle Rico batholith (Montes et al., 2012a). Molybdenite from Cerro Quema was dated by Re-Os at $70.74 \pm 0.29$ to $70.66 \pm 0.29$ Ma indicating an early Maastrichtian age for high sulphidation epithermal Au-Cu mineralization that was contemporary with dome emplacement (Perelló et al., 2020): the Ar-Ar dates dates are younger than the Re-Os dates and represent cooling ages.

Gold mineralization at Cerro Quema occurs in several zones along a $15 \mathrm{~km}$ E-W trend including the La Pava, Quemita, Quema and La Mesita deposits (Figures 9 to 11). The host rocks are a hornblende phyric dome, flows and pyroclastic rocks of andesitic to dacitic composition. Mineralization is hosted by a core of vuggy silica surrounded by an advanced argillic alteration zone

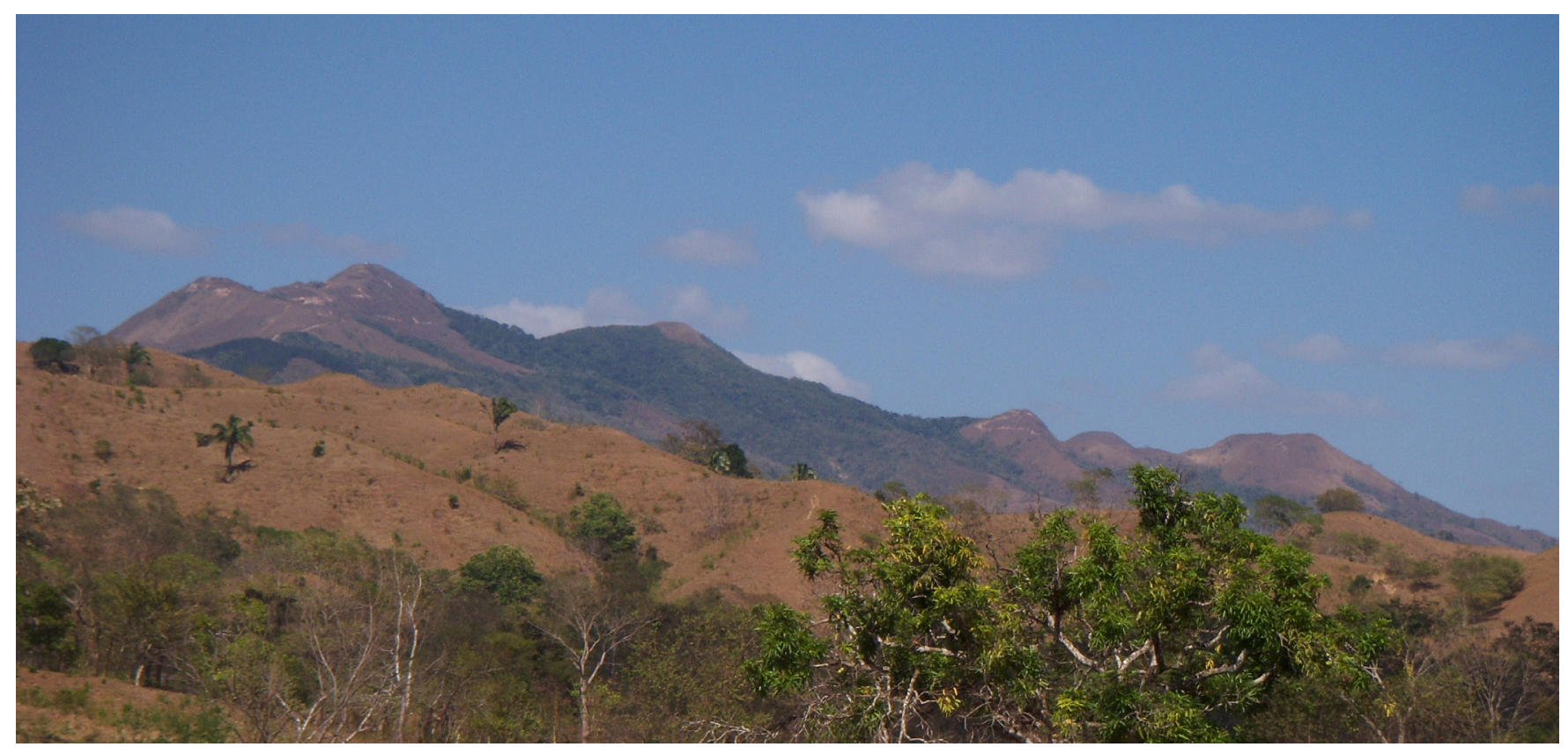

Figure 11 The Cerro Quema deposit looking southwest with Cerro La Pava on the left and Cerro Quema third right (S. Redwood, 2009). 
(with quartz, alunite-natroalunite, aluminium phosphate sulphate (APS) minerals, dickite, pyrophyllite, kaolinite, barite and rutile) with medium to low grade mineralization (Figure 10). This is surrounded by an intermediate argillic zone with illite and smectite, and beyond this by a propylitic zone containing pyrite, chlorite, calcite and siderite. The oxide zone is up to $150 \mathrm{~m}$ deep and contains jarosite, hematite and goethite, with breccias. The hypogene sulphide mineralization is pyrite (up to $35 \%$ ), enargite, tennantite and chalcopyrite. Supergene chalcocite and minor covellite occur below the oxide zone (Corral et al., 2016).

Deep drilling below La Pava and other mineralized centers identified porphyry-style A and B veining overprinted by advanced argillic alteration. The veins are highly contorted, banded and planar quartz veinlet stockworks and sheeted zones in pyrophyllite- and sericite-bearing patchy-textured rock, associated with chalcopyrite-molybdenite mineralization, and potassium feldspar-magnetite alteration (Pershimco press release 14-11-2013; Tortelli et al., 2014; Perelló et al., 2020). This indicates that the Cerro Quema system is close to the epithermal-porphyry transition.

\subsubsection{PITALOZA HIGH SULPHIDATION EPITHERMAL Au PROSPECT}

The Pitaloza high sulphidation epithermal gold prospect is located $20 \mathrm{~km}$ west-northwest of the Cerro Quema Au-Cu deposit. The project, originally called Santa Clara, was explored by Cyprus Minerals Corp. with Transworld Exploraciones S. A. in 1991-1995. More recent exploration was carried out by Bellhaven Copper \& Gold Inc. in 2004-2010.

The geology has been described by Folk (2004a), Hedenquist (2010) and Medina Molero et al. (2014). Alteration occurs in three zones at Bejucosa, Caracucho and Cementerio in an area of about 3-4 km². The host rocks are dacite domes with block and ash flows at Caracucho cutting dacitic to andesitic lapilli and ash tuffs of the Rio Quema Formation which are intensely altered and are cross cut by an unaltered, post-mineral diorite intrusion of the El Montuoso suite.
Alteration at Pitaloza includes quartz-pyrite, granular quartz, vuggy silica (probably after quartz-alunite-pyrite rather than residual quartz) in structural ledges and pervasive zones, quartz-illite-pyrite and advanced argillic with quartz, dickite, alunite, diaspore, zunyite, pyrophyllite and andalusite, with abundant pyrite which is oxidized to hematite and jarosite. The copper sulphides are enargite and supergene chalcocite and covellite. Silicic alteration at Bejucosa may be stratiform with structural feeders. The system is a high sulphidation epithermal Au-Cu and is similar to Cerro Quema, with a deeper level of the advanced argillic zone exposed as indicated by the higher temperature minerals pyrophyllite and andalusite.

Cyprus drilled 9 short holes to test the gold oxides at Caracucho in 1994. The best results were $26.52 \mathrm{~m}$ at $0.70 \mathrm{~g} / \mathrm{t} \mathrm{Au}$ and $15.25 \mathrm{~m}$ at 1.80 $\mathrm{g} / \mathrm{t} \mathrm{Au}$. The oxide zone was 25.00-34.15 m deep. Some holes ended in the supergene zone with $\mathrm{Cu}$ and Au with grades of $7.32 \mathrm{~m}$ at $0.41 \mathrm{~g} / \mathrm{t} \mathrm{Au}$ and $0.35 \% \mathrm{Cu}$ from $32.62 \mathrm{~m}$, and $7.31 \mathrm{~m}$ at $0.58 \mathrm{~g} / \mathrm{t}$ $\mathrm{Au}$ and $0.32 \% \mathrm{Cu}$ from $34.15 \mathrm{~m}$.

Bellhaven dug exploration trenches at Bejucosa in 2006-2010 which returned $52 \mathrm{~m}$ at $2.3 \mathrm{~g} / \mathrm{t} \mathrm{Au}$, $16 \mathrm{~m}$ at $1.8 \mathrm{~g} / \mathrm{t} \mathrm{Au}, 12 \mathrm{~m}$ at $8.9 \mathrm{~g} / \mathrm{t} \mathrm{Au}, 34 \mathrm{~m}$ at $0.6 \mathrm{~g} / \mathrm{t} \mathrm{Au} .18 \mathrm{~m}$ at $4.4 \mathrm{~g} / \mathrm{t} \mathrm{Au}$, and $10 \mathrm{~m}$ at $1.0 \mathrm{~g} / \mathrm{t}$ $\mathrm{Au}$. It drilled five holes at Bejucosa in 2010 with $19.95 \mathrm{~m}$ at $0.19 \mathrm{~g} / \mathrm{t} \mathrm{Au}$ and $8.16 \mathrm{~m}$ at $0.16 \mathrm{~g} / \mathrm{t}$ $\mathrm{Au}$ and $0.68 \% \mathrm{Cu}$. The much higher gold grades on surface may be due to enrichment in the oxide zone.

\subsubsection{LOS ÑOPOS HIGH SULPHIDATION EPITHERMAL Au-Cu-Mo PROSPECT}

The Los Nopos prospect is located in the western part of the Azuero belt. Mineralization was discovered by the Phase 1 UN stream sediment survey and it was followed up in Phase II with further geochemistry, but no drilling (UN, 1972b). The geology comprises dacites and andesites with quartz diorite, granodiorite and diabase of the Loma El Montuoso batholith, Cretaceous limestone and greenschists. Stream sediment samples gave up to $440 \mathrm{ppm} \mathrm{Cu}$, rock samples up 
to $2.2 \% \mathrm{Cu}$ and $1,200 \mathrm{ppm} \mathrm{Zn}$, and soil samples gave an area anomalous in $\mathrm{Cu}-\mathrm{Mo}$, associated with silicification. Gold was not assayed. The style of mineralization is interpreted as high sulphidation epithermal Au-Cu-Mo.

\subsubsection{CERRO VIEJO HIGH SULPHIDATION EPITHERMAL Au PROSPECT}

The Cerro Viejo high sulphidation epithermal gold prospect is a large massif about $3 \mathrm{~km}$ long trending E-W and $924 \mathrm{~m}$ high on Filo Cabuya, about $30 \mathrm{~km}$ west of the Cerro Quema Au-Cu deposit in the western part Azuero Au-Cu belt. The project was explored by Cyprus Minerals Corp. with Transworld Exploraciones S. A. in 1990-1994, and by Bellhaven Copper \& Gold Inc. in 2004-2010. Cyprus drilled 13 short holes in 1994 but the results are not available. It was described for Bellhaven by Hedenquist (2010). The geology consists of lapilli tuffs, block and ash deposits and a probable dome, as well as ridges of hydrothermal breccia with silicified clasts. Alteration is residual quartz and advanced argillic with a gossan. Surface samples returned grades up to 1.1 and $0.9 \mathrm{~g} / \mathrm{t} \mathrm{Au}$.

\subsubsection{QUEBRADA BARRO HIGH SULPHIDATION EPITHERMAL} Au-Cu PROSPECT

The Quebrada Barro prospect is located in the western part of the Azuero belt. Mineralization was discovered by the Phase 1 UN stream sediment survey and followed up in Phase II with 9 short drill holes (314.4 m) (UN, 1972b). The geology is andesitic to dacitic flows, tuffs and tuff breccias and diorites on the SW margin of the Loma El Montuoso quartz diorite batholith. Mineralization is associated with silicification and kaolinite alteration adjacent to an E-W trending fault and consists of pyrite, chalcopyrite, molybdenite, gold and minor bornite, enargite and barite, with secondary chalcocite and covellite. Drill intersections included 5.9 $\mathrm{m}$ at $1.08 \% \mathrm{Cu}, 0.90 \mathrm{~g} / \mathrm{t}$ Au and $140 \mathrm{ppm} \mathrm{Mo}$, and $4.37 \mathrm{~m}$ at $0.46 \% \mathrm{Cu}, 1.3 \mathrm{~g} / \mathrm{t} \mathrm{Au}, 4.0 \mathrm{~g} / \mathrm{t} \mathrm{Ag}$ and 51 ppm Mo. The style of mineralization is intermediate to high sulphidation epithermal and is similar to the sulphide zone at Cerro Quema.
Other occurrences of base metal mineralization located by the UN project in Azuero at the contact of quartz diorite batholiths with dacite lavas were $\mathrm{Pb}-\mathrm{Zn}$ at Los Zurrones (Montijo), $\mathrm{Cu}$ at Cerro Nopos (Los Pozos), and disseminated $\mathrm{Cu}$ with anomalous Mo and porphyry characteristics at Iguana (Montijo) (del Giudice and Recchi, 1969).

\subsubsection{LOS POZOS EPITHERMAL A U PROSPECT}

Los Pozos (Herrera) epithermal gold prospect was explored by the UNDP program and later by BHP Minerals in 1995-1997. Alteration is hosted by late Cretaceous to Paleocene basaltic andesite lavas and pyroclastic rocks with extensive silicic, argillic, sericitic and propylitic alteration and with anomalous gold on surface.

\subsubsection{CERRO NEGRO LOW SULPHIDATION EPITHERMAL Au-Ag PROSPECT}

The Cerro Negro mine was reported to have been the first Spanish silver mine in the Americas in the early $16^{\text {th }}$ century, and the silver coined at a mint at the town of Nata (Riddell, 1927). The Cerro Negro epithermal gold prospect, about $20 \mathrm{~km}$ NW of Chitre, was explored by Tenneco Minerals Company (Minera Orion Ltda, 1986-1988), Echo Bay (1988-1989) and Noranda (1992-1993). Tenneco/Echo Bay drilled 24 holes for 1,873 m with short, high grade intercepts in the Paris Sur area such as $0.6 \mathrm{~m}$ at $47.2 \mathrm{~g} / \mathrm{t} \mathrm{Au}$ and $16.6 \mathrm{~g} / \mathrm{t} \mathrm{Ag}, 1.0 \mathrm{~m}$ at $23.3 \mathrm{~g} / \mathrm{t} \mathrm{Au}$ and $28.2 \mathrm{~g} / \mathrm{t} \mathrm{Ag}$, and $1.2 \mathrm{~m}$ at 4.9 $\mathrm{g} / \mathrm{t} \mathrm{Au}$ and $12.6 \mathrm{~g} / \mathrm{t} \mathrm{Ag}$.

Gold mineralization is hosted by banded quartz veins up to $3.0 \mathrm{~m}$ wide and $1,000 \mathrm{~m}$ long cutting dacite domes and ash tuff, lapilli tuff and tuff breccia with widespread pervasive silicification and argillic alteration over a large area. The prospect is a large, low sulphidation epithermal gold-silver system similar to those of the Veraguas Gold Belt; however, it may be older as although it has not been dated, it lies along strike of the Eocene volcanic arc of the northern part of the Azuero Peninsula. 


\subsubsection{EL GUÁCIMO Cu DEPOSIT}

The El Guácimo (or El Guásimo) copper mine at Pesé was mined in the late $19^{\text {th }}$ century (Posada, 1898) and again in about 1950 when a small amount of high grade copper ore was mined. Copper mineralization is hosted by tuffs and comprises veins with copper sulphides and carbonates accompanied by wall-rock alteration to chlorite, zeolite, epidote, chalcedony, calcite and pyrite (del Giudice and Recchi, 1969). There is no other geological information about this deposit which appears to be an epithermal vein.

\subsubsection{RIO TINTO (OCÚ) Cu DEPOSIT}

Copper was mined at the Rio Tinto copper mine at Ocú in the late $19^{\text {th }}$ century (Posada, 1898). There is no geological information about the deposit, which may be have been an epithermal vein hosted by basalts or tuffs similar to El Guácimo (del Giudice and Recchi, 1969).

\subsubsection{2 .EL GALLO Au-Ag-Pb DEPOSIT}

The El Gallo gold mine at Las Minas is described as a Spanish $16^{\text {th }}$ century discovery which was mined in a glory hole or open pit about $45 \mathrm{~m}$ in diameter on the hill-top (Riddell, 1927). It was mined for $\mathrm{Au}-\mathrm{Ag}-\mathrm{Pb}$ in the late 19th century (Posada, 1898; Oller, 1933, 1975). The Panama Corporation explored it by extending one of the five tunnels further into the hill (Riddell, 1927), and the tunnels were reopened by the UN project, which found galena (del Giudice and Recchi, 1969). There are no geological descriptions but the open pit with both precious and base metals suggests a breccia pipe of intermediate sulphidation epithermal style.

The nearby Don Juan Cu mine at La Mina, also mined in the late $19^{\text {th }}$ century (Posada, 1898), may be related to the same intermediate sulphidation epithermal system.

\subsubsection{SONÁ PORPHYRY Au-CU PROSPECT}

The Soná prospect is a gold-rich porphyry $\mathrm{Cu}$ system with abundant magnetite. It is the only gold-rich porphyry known in Panama and is simi- lar to those of the Middle Cauca Gold Belt of NW Colombia. It has not been dated but is tentatively interpreted to belong to the Eocene arc, although it may be of Miocene age. Historical gold mining is indicated by the place name, Quebrada de Oro. Cyprus Minerals Corp. discovered the mineralization in the 1990s, and Oro Gold Resources Ltd. carried out exploration in the 2000 s, but it has not been drilled.

Mineralization is hosted by a multi-phase diorite porphyry which intrudes lithic lapilli andesite tuff on the north side. The diorites have relic potassic alteration (potassium feldspar) with disseminated magnetite, overprinted by sericite alteration and by supergene argillic alteration. There is a dense stockwork of quartz A and B veinlets, magnetite veinlets, and banded quartz-magnetite veinlets with pyrite, chalcopyrite and magnetite, and locally surficial oxidation to malachite and neotocite. Gold mineralization as defined by surface geochemistry in soils, rocks, stream sediment samples occurs over an area of 2 to $3 \mathrm{~km}$ with a NW trend.

\section{Middle Arc: Oligocene-lower Miocene porphyry and epithermal deposits}

\subsection{THE OLIGOGENE - LOWER MIOGENE ARG AND MINERALIZATION}

The Middle Arc of Oligocene-lower Miocene age post-dates the oroclinal bending and offset of the Early Arc. The Middle Arc is arguably the most important $\mathrm{Cu}-\mathrm{Au}$ metallotect in economic terms in Panama as it hosts the Cobre Panama porphyry $\mathrm{Cu}$ deposit and the Espiritu Santo de Cana epithermal Au deposit. The Oligocene - lower Miocene volcanic arc (31-18 Ma) occurs on the southern side of eastern Panama in the Darien mountains which host epithermal Au mineralization at Cana and Rio Mogue; in the Majé mountains with porphyry $\mathrm{Cu}$ mineralization; the Pearl Islands with no known mineralization (Lissinna, 2005; Wegner et al., 2011); the Central Panama Volcanic Field with epithermal Au mineralization (Buchs et al., 2019a); and continues into western Panama in the 
Petaquilla porphyry Cu belt (Baker et al., 2016) and probably the Veraguas (Santa Fé) Au belt. Magmatism ceased in eastern and central Panama in the early Miocene.

Oligocene age plutonic rocks occur in the core of the Talamanca Cordillera in the Central Cordillera of western Panama-eastern Costa Rica exposed by rapid uplift associated with the subduction of the Cocos Ridge. They include middle Oligocene tholeiitic gabbros, the middle Oligocene El Barú plutonic complex (32.25 $\pm 2.25 \mathrm{Ma})$, the late Miocene Talamanca Intrusive Suite, and Pliocene-Pleistocene volcanic rocks (Drummond et al., 1995).

\subsection{DARIEN EPITHERMAL-PORPHYRY Au-Gu BELT}

\subsubsection{CANA PORPHYRY Cu-Au PROSPECT AND BRECCIA- HOSTED INTERMEDIATE SULPHIDATION EPITHERMAL A DEPOSIT}

The Espiritu Santo gold mine at Cana, known originally as Santa Cruz de Cana, was the most important historical gold mine in Panama. High grade epithermal gold mineralization is hosted by a breccia pipe in a porphyry system. The total gold endowment (production + resources) is estimated to be about 59 metric tons, much of it at grades $>1,000 \mathrm{~g} / \mathrm{t} \mathrm{Au}$. The geology and the mine have been described by Restrepo (1886, 1888), Woakes (1895, 1899, 1923), Chibas (1898), Low (1931), Oller (1933, 1975), Tower (1963), Tippett and Trever (1989) and Nelson (1995, 2007). It is located close to the Colombian border in the Pirre Massif at an altitude of 600-900 m, 245 km SW of Panama City.

The Espiritu Santo mine was worked by the Spaniards from before 1680 to 1727 , and is estimated to have produced more than 30 million pesos of gold in this period, equivalent to about 1.562 Moz or $48.6 \mathrm{t}$ of gold (Restrepo, 1886,1888). The mine was rediscovered and exploited by the Darien Gold Mining Company Ltd. of England from 1887 to 1912. It initially developed the El Rey Mine (or North Mine) with no important production, and then reopened the Espiritu Santo Mine (Woakes, 1895, 1899 and 1923). The mine was bought by Don Tomás Arias, one of the founders of the Republic of Panama, in 1914 who continued to operate it until 1926. The production from 18951910 was given as 230,443 ounces $(7.17 \mathrm{t}$ ) by Tower (1963) at grades of 45-70 g/t, and for 1900-1907 it was given as 142,236 ounces (4.42 t) by Oller (1933, 1975).

The Panama Corporation explored San Jose hill as a bulk mineable target in 1927-1932 and estimated reserves of $1.8 \mathrm{Mt}$ at $1 \mathrm{~g} / \mathrm{t} \mathrm{Au}$ and potential for $11 \mathrm{Mt}$ (Foster, 1939). The deposit was subsequently explored for porphyry copper and epithermal gold between 1964-1996 by various companies, with definition of a resource of about 108,000 ounces (3.36 t) grading $13.7 \mathrm{~g} / \mathrm{t}$ Au at the North Mine (Tippett and Trever, 1989).

The Pirre Massif is a NNE-trending rotated fault block in the transpressional East Panama Deformed Belt. The massif is bounded on the western side by a major N-S to NE-trending reverse fault, the Pirre or Rio Balsas Fault. Regional maps show the massif to be formed of an anticline of either the late Cretaceous Playa Venado Formation basalt pillow lavas (DGRM, 1991), or the middle Eocene to Oligocene Darien Formation of tuff, agglomerate, chert and basalt in the lower part, and calcareous and siliceous mudstone, micritic calcarenite and volcaniclastic rocks in the upper part (Coates et al., 2004). The age of porphyry intrusion and mineralization is constrained to be post-Cretaceous in the first case, or late Oligocene or younger in the second case.

The deposit geology comprises andesite lavas and volcaniclastic rocks intruded by a circular hornblende-feldspar porphyry stock about 1,000$1,500 \mathrm{~m}$ in diameter and cross-cut by WNW-trending dykes (Figure 12; Nelson, 1995, 2007). Pervasive phyllic alteration with local potassic alteration is centered on the porphyry, with peripheral propylitic alteration. Drilling encountered deep porphyry-style mineralization including quartz veinlets with chalcopyrite. Other drill programs targeted gold mineralization at the North or El Rey Mine and San José hill, about which there is no geological information.

Most of the historical gold production was from the South Mine or Espiritu Santo Breccia Pipe, 


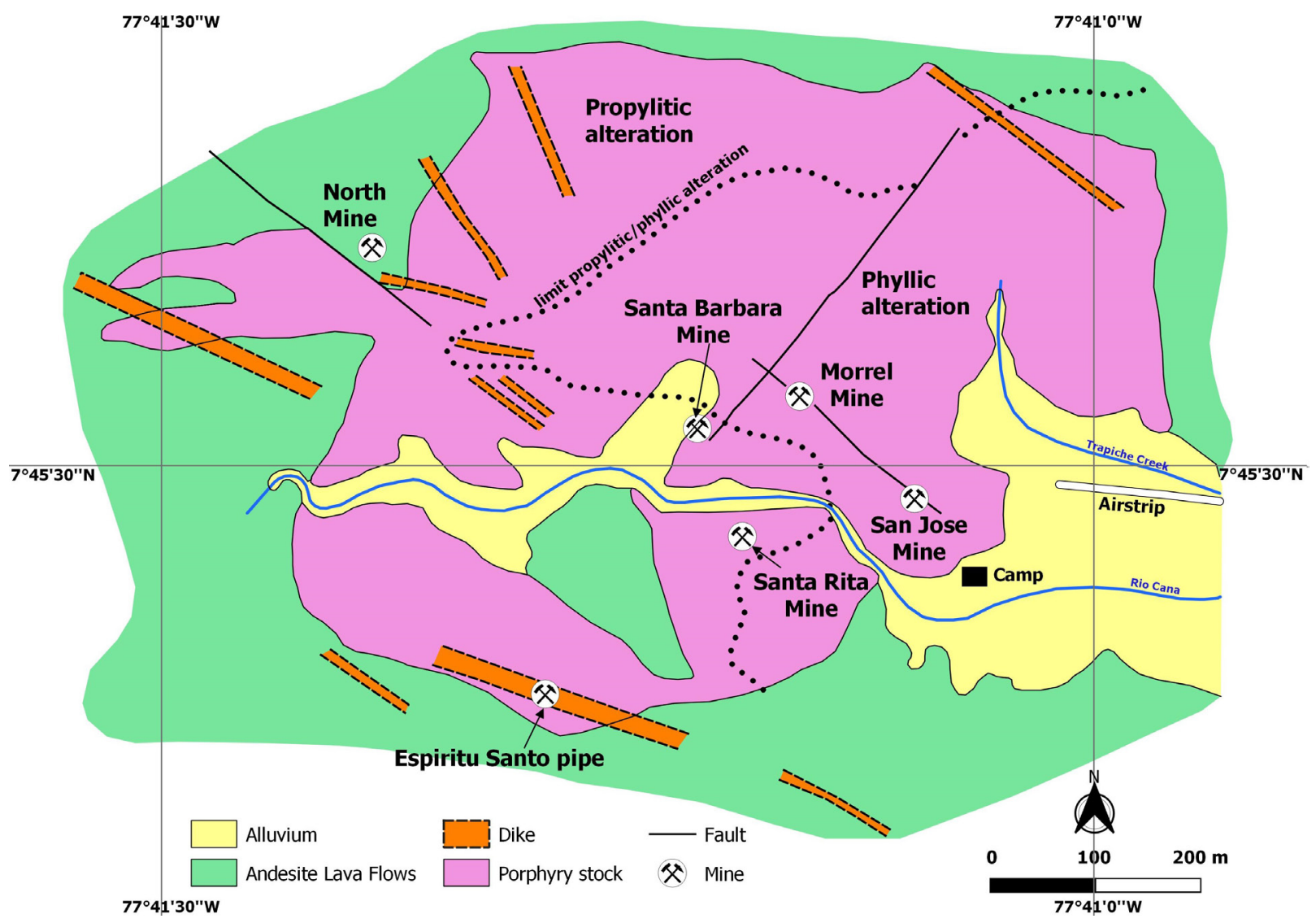

Figure 12 Geological map of the Cana gold deposit (modified after Nelson, 2007).

which is $25 \mathrm{~m}$ diameter with $70^{\circ}$ plunge to the SW, and was mined to a depth of $270 \mathrm{~m}$ with an average grade of $45-50 \mathrm{~g} / \mathrm{t} \mathrm{Au}$ (Figure 13). The breccia has angular rock fragments cemented by pyrite, sphalerite, galena, visible gold, quartz and calcite.

The Espiritu Santo deposit is interpreted as high grade Au-bearing, intermediate sulphidation epithermal mineralization with base metals in a phreatic or phreatomagmatic breccia pipe related to the Cana porphyry $\mathrm{Cu}-\mathrm{Au}$ system. Gold mineralization at the North and San José Mines is probably also epithermal. The porphyry stock and mineralization cross cut volcanic rocks of the Darien Formation, indicating an age of late Oligocene or younger.

\subsubsection{RIO MOGUE LOW SULPHIDATION EPITHERMAL AND CARBONATE-REPLACEMENT A P PROSPECT}

The Rio Mogue epithermal gold prospect is located in the Bagre Massif in the headwaters of the Rivers Marea (or Bagre), Mogue and Taimatí, a fault-bounded block in the transpressional East Panama Deformed Zone. Mineralization was discovered at Rio Mogue in 1974 by an unknown method, probably by the presence of artisanal placer gold mining, and it was explored in 19751978 by the Dirección General de Recursos Minerales (DGRM) under the Panama Proyecto Experimental. DGRM carried out $994.9 \mathrm{~m}$ of diamond drilling in 36 short holes with best intervals of 37.5 $\mathrm{m}$ at $2.11 \mathrm{~g} / \mathrm{t} \mathrm{Au}$ (including $1.5 \mathrm{~m}$ at $36.48 \mathrm{~g} / \mathrm{t}$ $\mathrm{Au} ; 12.5 \mathrm{~m}$ at $4.04 \mathrm{~g} / \mathrm{t} \mathrm{Au} ; 13.72 \mathrm{~m}$ at $2.97 \mathrm{~g} / \mathrm{t}$ $\mathrm{Au} ; 14.02 \mathrm{~m}$ at $1.78 \mathrm{~g} / \mathrm{t} \mathrm{Au}$; and $35.05 \mathrm{~m}$ at 1.64 $\mathrm{g} / \mathrm{t} \mathrm{Au}$. The project was explored in 1996-2000 by Paminexco and Minera Rayrock which drilled 10 Winkie holes for $390.8 \mathrm{~m}$.

The regional geology is shown as the late Cretaceous Playa Venado Formation of basalt pillow lavas overlain by inliers of sediments of the Eocene-Oligocene Tonosi Group and Oligocene-Miocene Topaliza Formation (DGRM, 


\section{FIG. 3.}

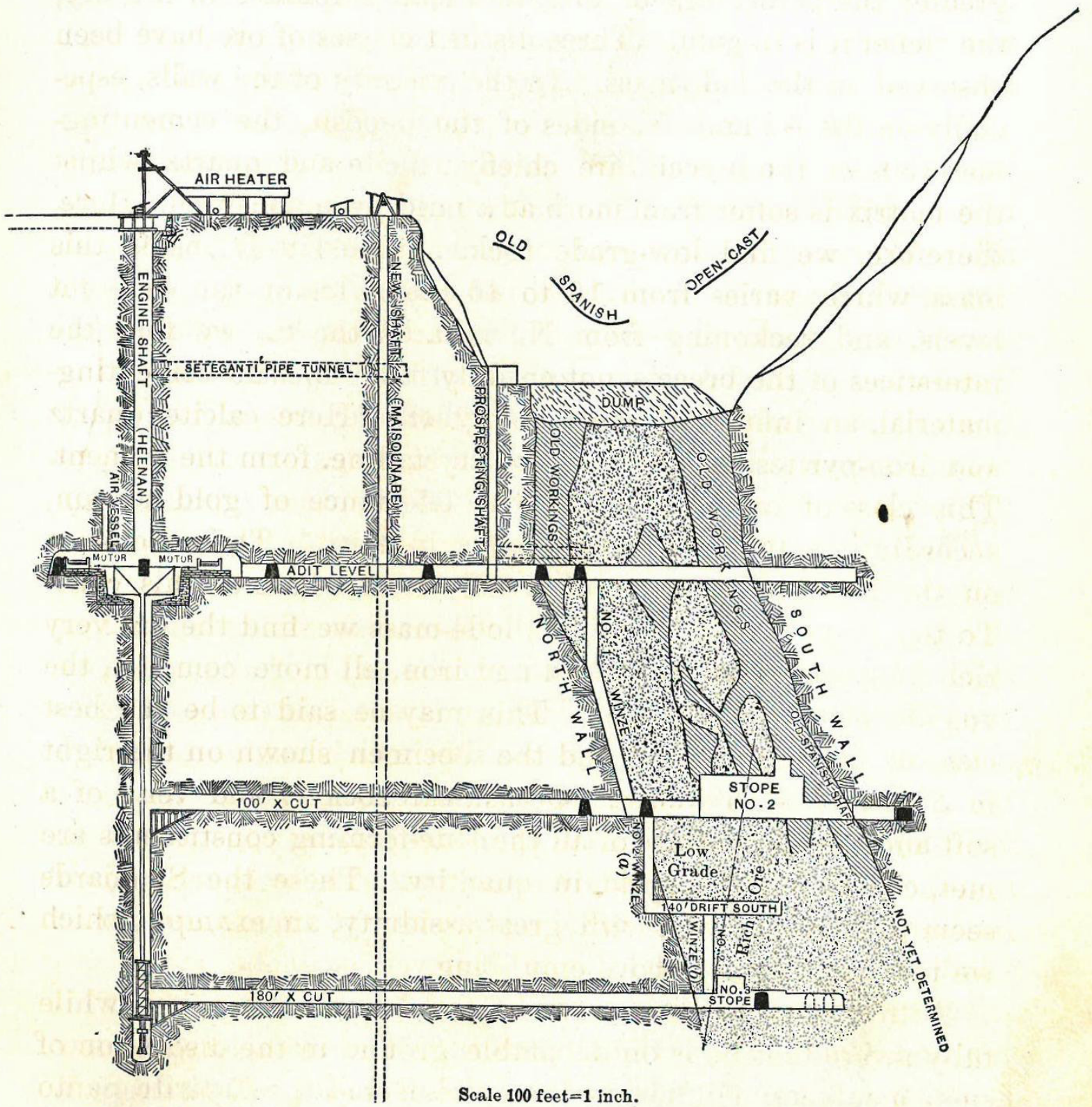

Section of the Espiritu Santo Mine, Cana, Re-worked by the Darien Mining Co., Ltd. 
1991). These are called the late Cretaceous to Paleocene San Blas Formation and the middle Eocene to Oligocene Darien Formation of tuff, agglomerate, chert and basalt in the lower part, and calcareous and siliceous mudstone, micritic calcarenite and volcaniclastic rocks in the upper part by Coates et al. (2004).

The geology of Rio Mogue comprises andesites and basalts of the Playa Venado Formation overlain by andesitic lavas, shale, limestone and limestone breccias, and finally by tuffs, and cut by dacitic porphyry intrusions. Alteration is silicic, argillic, propylitic and carbonate. Gold mineralization is associated with arsenian pyrite and is hosted by quartz veins and silicification including silicified limestones. Gold correlates with high As $(1,000$ s to $>10,000 \mathrm{ppm})$, accompanied by anomalous $\mathrm{Hg}$ and $\mathrm{Sb}$, with low $\mathrm{Ag}$ and base metals.

The presence of $\mathrm{Au}$ related to As-pyrite, anomalous As-Sb-Hg, low Ag and base metals, and silicified limestone suggests similarities with sedimentary rock-hosted disseminated gold deposits of the Carlin-type and, in particular, the carbonate-replacement style Mesel gold deposit which is located in an island arc in Sulawesi, Indonesia (Turner et al., 1994, 2002) in an analogous setting to Panama. Mineralization at Rio Mogue is probably related to the late stage dacite porphyry intrusions which cross cuts the Darien Formation and so is late Oligocene or younger in age.

\subsubsection{IPETI PORPHYRT Cu-Mo-Au PROSPECT}

The Ipeti porphyry $\mathrm{Cu}-\mathrm{Mo}-\mathrm{Au}$ prospect (also called Rio Guayabo, Ambroya and Majé) is located in the Majé mountains. It was described briefly by Kesler et al. (1977). Mineralization was discovered by a Cu-Mo stream sediment anomaly by a UNDP survey in 1969-1971 (UN, 1972a, 1972b) and it was explored from 1993-1999 by Aluviones de Panama S. A., International CanAlaska Resources Ltd. and International Taurus Resources Inc, which drilled 13 holes for 2,534 m. A soil survey defined $200 \mathrm{ppm} \mathrm{Cu}$ over an area of 1,200 m by $1,700 \mathrm{~m}$, with an inner zone $>500 \mathrm{ppm} \mathrm{Cu}$ of $100-400 \mathrm{~m}$ width, with samples up to $1,500 \mathrm{ppm}$
Cu. A soil Au anomaly $>50 \mathrm{ppb}$ coincident with $200 \mathrm{ppm} \mathrm{Cu}$, with up to 0.1 to $0.3 \mathrm{ppm} \mathrm{Au}$. The $\mathrm{Cu}-\mathrm{Au}$ anomalies are coincident with a magnetic high. The best drill result was $160.7 \mathrm{~m}$ at $0.20 \%$ $\mathrm{Cu}$ and $0.176 \mathrm{~g} / \mathrm{t} \mathrm{Au}$ including $29.5 \mathrm{~m}$ at $0.33 \%$ $\mathrm{Cu}$ and $0.269 \mathrm{~g} / \mathrm{t} \mathrm{Au}$.

The Majé Cordillera is a subvolcanic igneous complex of intrusives of basalt to dacite composition with adakite-like chemistry (Whattam et al., 2012). A diorite intrusion in the northern part of the cordillera was dated by $\mathrm{U}-\mathrm{Pb}$ on zircons at 18.9 $\pm 0.9 \mathrm{Ma}$ (Whattam et al., 2012). Mineralization at Ipeti is hosted by a multiphase stock and andesite tuffs and sediments, with potassic and propylitic alteration. Kesler et al. (1977) described biotite alteration as well as silicification and pyritization, but was unable to date the deposit.

\subsection{GENTRAL PANAMA VOLGANIC FIELD EPITHERMAL Au DEPOSITS}

\subsubsection{INTRODUCTION}

The Central Panama Volcanic Field of Oligocene to early Miocene age (ca 25 - $18 \mathrm{Ma}$ ), defined by Buchs et al. (2019a), which is traversed by the Panama Canal, has one historical gold mine as well as a number of indications of low temperature hydrothermal alteration. There were two phases of proximal volcanism associated with the formation of felsic stratovolcanoes in the Las Cascadas Volcanic Complex (ca $21 \mathrm{Ma}$ ), and monogenetic basaltic volcanoes of the Pedro Miguel Volcanic Complex (ca $18 \mathrm{Ma}$ and younger) (Buchs et al., 2019a). Distal volcanic tuffs were deposited at ca $25 \mathrm{Ma}$ in the Bas Obispo Formation, and regional volcanism continued between these two proximal volcanic phases shown by evidence in the Culebra, Cucaracha and La Boca Formations. The magma chemistry changed at ca $23 \mathrm{Ma}$ from calc-alkaline in the Bas Obispo Formation and Cerro Patacon group to tholeiitic in the Las Cascadas and Pedro Miguel Formations and possibly alkaline/transitional, consistent with suppression of water in the subduction zone (Buchs et al., 2019b). The age of the youngest volcanism in the canal is similar to that of the youngest known arc volcanism in east- 
ern Panama at ca $18 \mathrm{Ma}$. This is interpreted to be the result of magmatic cessation along a volcanic arc following the breakup of the Farallon plate at ca 23 $\mathrm{Ma}$, and the transition from orthogonal to oblique subduction in Central and Eastern Panama, which suppressed hydrous melting in the subduction zone (Buchs et al., 2019b).

The tectonic setting of the volcanism and sedimentation has been described as hinge-basin rift setting (Farris et al., 2011, 2017). Alternatively, Buchs et al (2019b) consider that volcanism was not induced by extension, and that sedimentation took place between volcanoes without a basin. The early development (ca 40-32 Ma) of a transisthmian fault system in the Canal area probably helped the extraction of the last supra-subduction melts. Despite the change to anhydrous magmatism, low sulphidation hydrothermal systems were developed.

Gold deposits occur at Emperador and another further north in basement volcanic rocks at Cerro Santa Rita, near Sabanita. There are also widespread indications of low temperature hydrothermal alteration. These include green-blue to orange chalcedony, agate and minor quartz cementing pseudo-breccias in strongly jointed basalt plugs of the Pedro Miguel Formation at the Maria Eugenia quarries; veinlets and crackle breccias with chalcedony, opal, quartz and zeolites, and veinlets of calcite-pyrite in tuffs of Las Cascadas Formation near Bas Obispo; zeolite and calcite veinlets and vesicles in volcanic rocks of the Bas Obispo Formation, Bas Obispo cut; and veinlets and breccias with chalcedony, opal, quartz and zeolites in the Cucaracha Formation in the Hodge's Hill cut. In addition, shales of the Cucaracha Formation in the Culebra Cut contain very fine grained pyrite in sufficient amounts to have caused ground heating, smoking and even premature detonation of dynamite due to exothermic oxidation on exposure to air during the canal excavations (MacDonald, 1915).

\subsubsection{EMPERADOR EPITHERMAL AU DEPOSIT}

Gold was mined from placers and quartz veins in the Emperador deposit in the upper parts of the Rivers Sardinilla and Quebrada de Oro, tributaries of the River Obispo (now part of the Panama Canal) and the River Chagres respectively, in the former Emperador (Empire) district. Mining was carried out in Spanish times and again in the second half of the $19^{\text {th }}$ century.

Gold mineralization is hosted by the Las Cascadas Volcanic Complex (Buchs et al., 2019a). The gold deposit is about $1,000 \mathrm{~m}$ long with a NNW trend. Gold mineralization was described as occurring on multiple fractures with silicified and pyritized wall rock which resembled veins, accompanied by cinnabar, and strongly oxidized at surface, in a small quartz phyric dacite porphyry stock and in altered andesitic to dacitic rocks (Anon, 1882; Woodring, 1957), and is cut by unaltered post-mineral rhyolite dykes. Alteration is silica and sericite-pyrite, including a silicified polymict breccia. Vein float comprises drusy to colloform quartz veinlets, chalcedony and jasper. The alteration and veining are typical of low sulphidation epithermal deposits.

\subsubsection{SANTA RITA Au DEPOSIT}

Gold mineralization occurs in quartz-sulfide veinlets in olivine-rich basalt of the Cretaceous Playa Venado Formation on Santa Rita Hill southeast of the town of Sabanitas in a zone of about 2,000 $\mathrm{m} \mathrm{N}$-S, with alluvial gold to the south. Woodring (1957) described evidence for three periods of mining: remnants of large stone mortars from "indigenous operations"; caved adits associated with a French boiler with the date 1883; and "modern adits". The mine gave the name to Bahia de las Minas (Mines Bay) on the Caribbean coast to the north, into which the streams drain. There is no record of the grade or tonnage mined. The DGRM carried out exploration Santa Rita including trenching and drilling as part of the Gold Project in 1979-1982. The style of mineralization appears to be low or intermediate sulphidation epithermal and is probably related to volcanism in the nearby Central Panama Volcanic Field, although it may be older and related to the Cretaceous volcanic host rocks. 


\subsection{PETAQUILLA PORPHYRY Gu BELT}

\subsubsection{THE OLIGOCENE ARC}

The Cobre Panama porphyry deposit is of Oligocene age and is located in low altitude rain forest in the Caribbean lowlands north of the Central Cordillera (Figure 14). The Oligocene belt is only known here in western Panama but it may well continue west to the Veraguas epithermal Au belt, which is undated.

The regional geology of the Cobre Panama deposit is dominated by the Petaquilla batholith of granodiorite composition which is about 25 $\mathrm{km}$ long by $10 \mathrm{~km}$ wide and trends northwest to the Caribbean Sea (Figure 14). Economic copper mineralization occurs in seven separate porphyry deposits situated on the southern margin of the batholith and is hosted by granodiorite, multiphase quartz-feldspar-hornblende porphyries, and andesitic volcanic rocks (Speidel et al., 2001; Baker et al., 2016). The Petaquilla batholith was emplaced over a period of about 4 million years from $32.20 \pm 0.76 \mathrm{Ma}$ to $28.28 \pm 0.61 \mathrm{Ma}$ in the lower Oligocene, while the porphyry stocks and dykes were emplaced over about 2 million years from $28.96 \pm 0.62 \mathrm{Ma}$ to $27.48 \pm 0.68 \mathrm{Ma}$, based on $\mathrm{Ar}-\mathrm{Ar}$ and $\mathrm{U}-\mathrm{Pb}$ zircon dating (Speidel et al., 2001; Whattam et al., 2012; Baker et al., 2016). These intrude andesitic volcanic rocks with a late Eocene biostratigraphic age (37.8-33.9 Ma), based on larger foraminifera in thin limestone beds (Redwood et al., 2021).

\subsubsection{COBRE PANAMA (PETAQUILLA) PORPHTRY Cu-Mo-Au-Ag} DEPOSITS

Seven porphyry $\mathrm{Cu}$ deposits make up the Cobre Panama deposit: Botija, La Colina (previously called Petaquilla), Medio, Valle Grande, Balboa, Brazo and Botija Abajo (Figure 15). They occur in a $9 \mathrm{~km}$ long WNW-trending zone with a width of $4.5 \mathrm{~km}$. In addition, there are several other porphyry $\mathrm{Cu}$ prospects to the north including Nueva Lucha and Palmilla, and the Lata epithermal gold prospect. The Cobre Panama deposit was described by Kesler et al. (1977), Speidel et al. (2001), Whattam et al. (2012), Ireland et al. (2014), Baker et al. (2016), Sepp and Dilles (2018), Redwood et al. (2021) and several NI 43-101 technical reports, the most recent being by Gray et al. (2019).

The Petaquilla porphyry deposit, as it was called originally, was discovered by a regional stream sediment geochemistry survey by UNDP in 1968 (Huhta, 1991). It was explored from 19711977 by Panama Mineral Resources Development Co. Ltd. (PMRD), a Japanese consortium, and from 1991-1998 by Minnova (later called Metall Mining Corp. and subsequently Inmet Mining Corp.), Adrian Resources and Teck Cominco Ltd. The project was reactivated in 2003. Inmet consolidated $100 \%$ ownership of the Petaquilla deposit by 2008 and changed the name to Cobre Panama. First Quantum Minerals Ltd. bought Inmet in 2013 and the current ownership is First Quantum, 90\% and Korea Panama Mining Corp. (KORES), $10 \%$ through the operator Minera Panama S.A. (MPSA). The mine started production in 2019.

The Cobre Panama deposit contains measured and indicated mineral resources of $3,657 \mathrm{Mt}$ grading $0.37 \% \mathrm{Cu}, 0.07 \mathrm{~g} / \mathrm{t} \mathrm{Au}, 1.34 \mathrm{~g} / \mathrm{t} \mathrm{Ag}$ and $0.006 \%$ Mo in seven deposits (Figure 15), plus inferred mineral resources of $1,097 \mathrm{Mt}$ at $0.26 \%$ $\mathrm{Cu}, 0.04 \mathrm{~g} / \mathrm{t} \mathrm{Au}, 1.09 \mathrm{~g} / \mathrm{t} \mathrm{Ag}$ and $0.005 \%$ Mo at a cut-off grade of $0.15 \% \mathrm{Cu}$ (Gray et al., 2019). The total contained metal is $16.38 \mathrm{Mt}$ of copper, $300 \mathrm{t}$ of gold, 6,096 $\mathrm{t}$ of silver and 274,000 $\mathrm{t}$ of molybdenum. The resources include proven and probable mineral reserves of $3,143.7 \mathrm{Mt}$ grading 0.38\% Cu, $0.07 \mathrm{~g} / \mathrm{t} \mathrm{Au}, 1.37 \mathrm{~g} / \mathrm{t} \mathrm{Ag}$ and 59.38 ppm Mo. The plant capacity is $47 \mathrm{Mt}$ per year in 2019 increasing to $100 \mathrm{Mt}$ per year in 2023. Average annual copper in concentrates production is 310,000 metric tons of $\mathrm{Cu}$ rising to 377,000 metric tons per year, plus average annual by-products of $3.33 \mathrm{t} \mathrm{Au}, 52.88 \mathrm{Ag}$ and 2,717 t Mo. The mine life is 35 years to 2054 .

The dominant alteration types are chlorite, illite and smectite which overprint potassic alteration, which is preserved in certain zones with secondary biotite and potassium feldspar such as the higher 


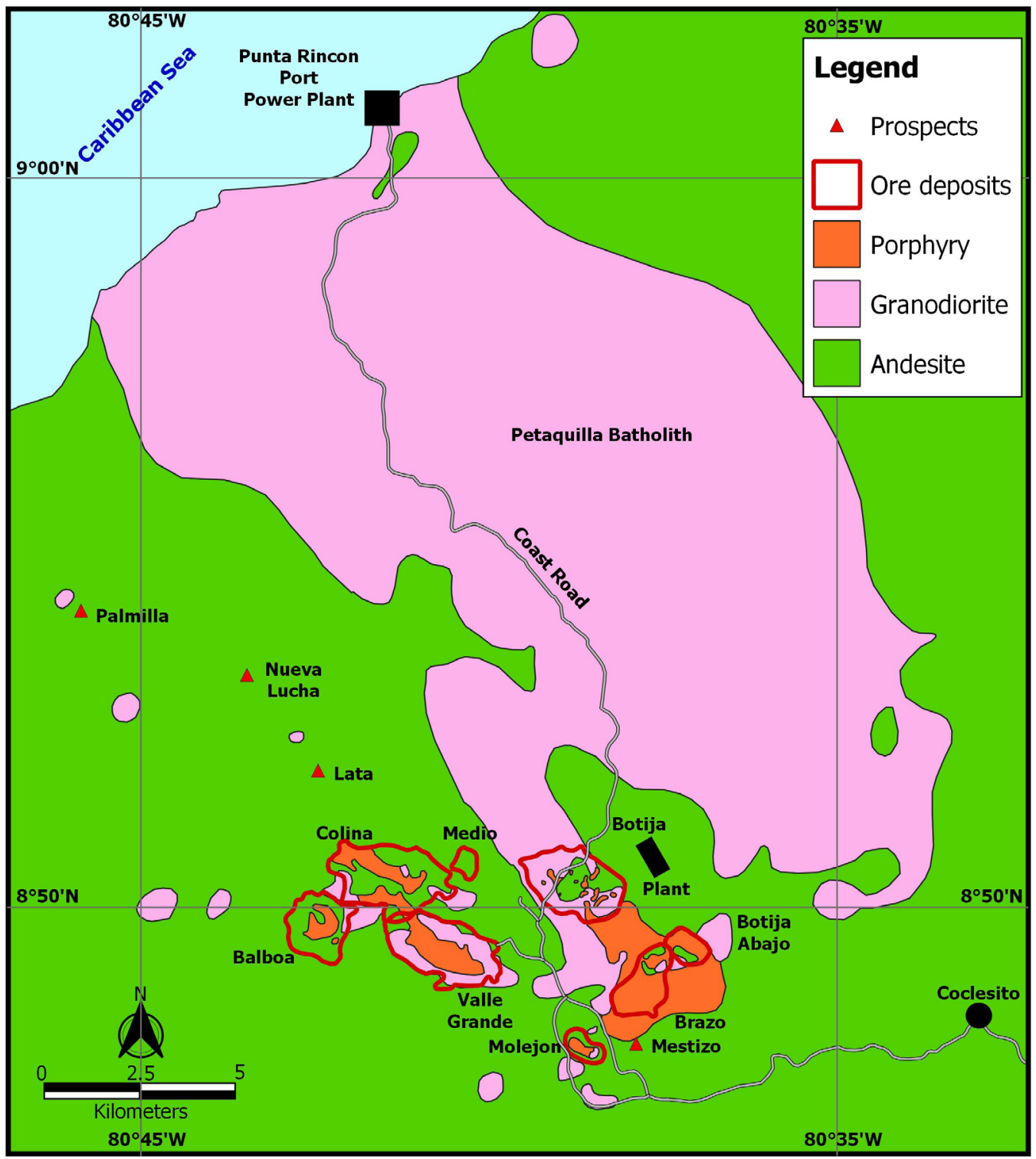

Figure 14 The regional geology of the Cobre Panama deposit (modified after Speidel et al., 2001 and Baker et al., 2016)

grade core at Botija (Speidel et al., 2001). Quartz sulphide \pm magnetite $\mathrm{A}$ and $\mathrm{B}$ veinlets are evidence of former, more widespread potassic alteration. Sericite-pyrite and advanced argillic (dickite, pyrophyllite) alteration lithocap roots are preserved in the upper parts of three deposits, Balboa, Brazo and Valle Grande, and quartz-pyrite D veinlets with sericite halos occur Valle Grande and the upper part of Botija.

Hypogene sulphides occur as disseminations, micro-veinlets, fracture fillings, and quartz-sul- phide stockworks. Chalcopyrite is the dominant copper mineral with lesser bornite, and they are accompanied by pyrite. Traces of molybdenite are commonly found in quartz veinlets. The deposits have a saprolitic weathering cap underlain directly by hypogene mineralization with no oxidation or enrichment except at the Brazo deposit which has a leached cap and a supergene chalcocite enrichment zone of limited extent, and Valle Grande which has oxidation, in both cases formed as a result of the pyrite-rich lithocap. 


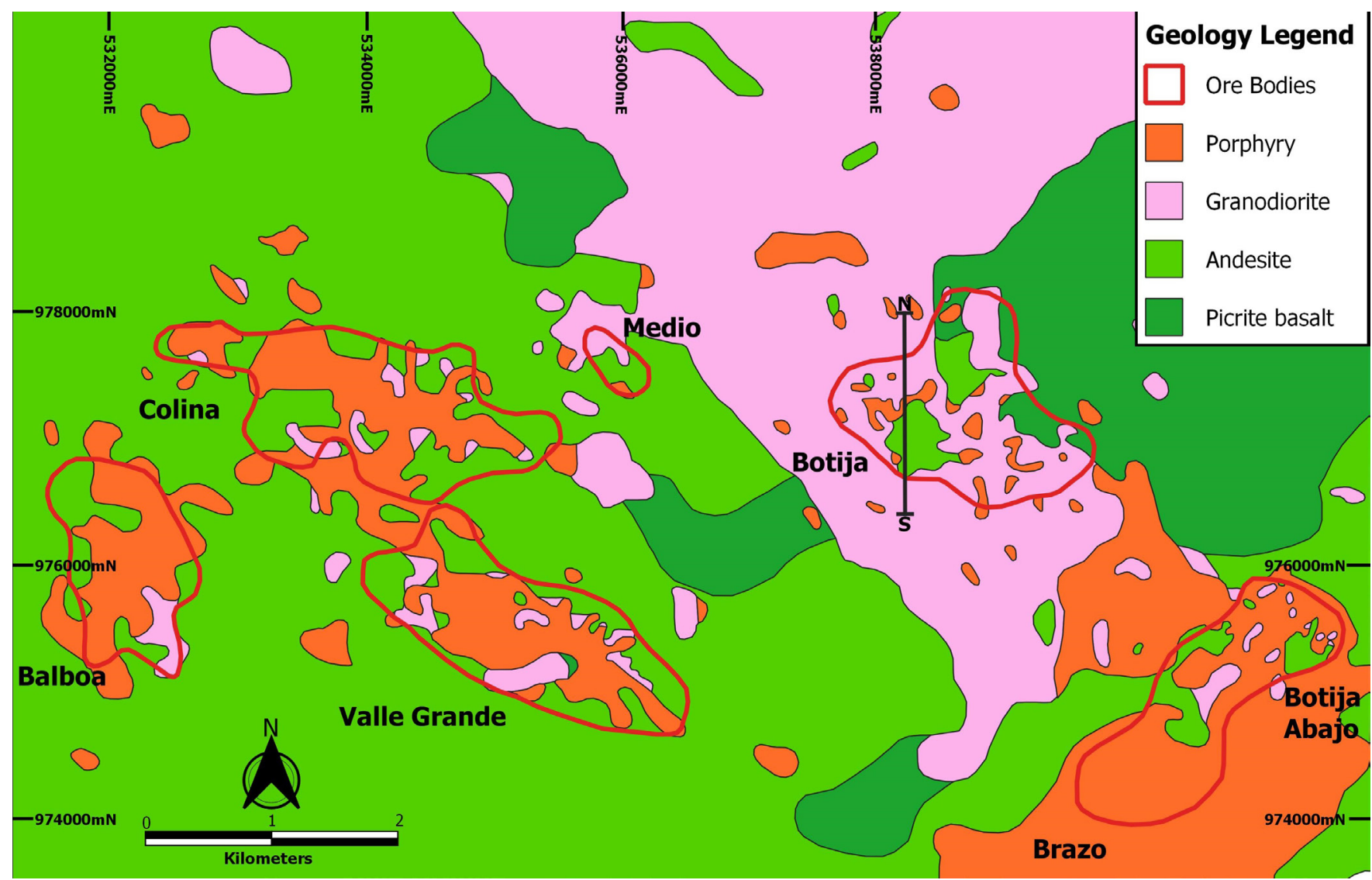

Figure 15 The geology of the porphyry copper deposits at the Cobre Panama deposit (modified from Spiedel et al., 2001).

The Botija deposit (Figure 16), the first to be mined, is hosted mainly by the Petaquilla batholith and related porphyries. The batholithic rocks are hornblende-bearing granodiorites. The porphyries have crowded phenocrysts. Alteration consists of a strong silica-chlorite in the periphery with illite-smectite-chlorite alteration in the higher grade central areas interpreted as lower temperature overprint of pre-existing potassic alteration.

The other deposits, Colina, Valle Grande, Balboa, Brazo and Botija Abajo, being located further from the batholith contact, have only a minor component of batholithic host rock and are hosted by feldspar-rich hornblende-bearing porphyries with or without quartz, and andesite to basalt flows and pyroclastic rocks. Each of the porphyry deposits has a different suite of porphyry intrusions indicating that they are separate intrusive centers. The Colina deposit is characterized by feldspar-quartz-hornblende bearing porphyries intruding hornfelsed and propylitically altered andesites. Magnetite-pyrite-epidote rich skarns up to $15 \mathrm{~m}$ thick are developed on the northeast margins of Colina and replace andesitic tuffs. Quartz porphyritic stocks in the southwestern area are associated with gold enrichment. The central southern sector of the Colina and Valle Grande deposits are dominated by milled matrix breccias with hydrothermal cement, as well as intrusion breccias. The Balboa deposit is hosted predominantly in a feldspar-quartz-hornblende porphyry and exhibits strong sulphide network veining associated with sodic-calcic alteration in the center of the deposit. Post-mineral mafic to intermediate dikes are present in all deposits.

The Cobre Panama porphyry deposits are unusual in that most of the mineralization occurs in a series of tabular bodies dipping at $10-45^{\circ}$ northwest (Botija, Colina, Brazo, Botija Abajo, Valle Grande) rather than upright bodies which 


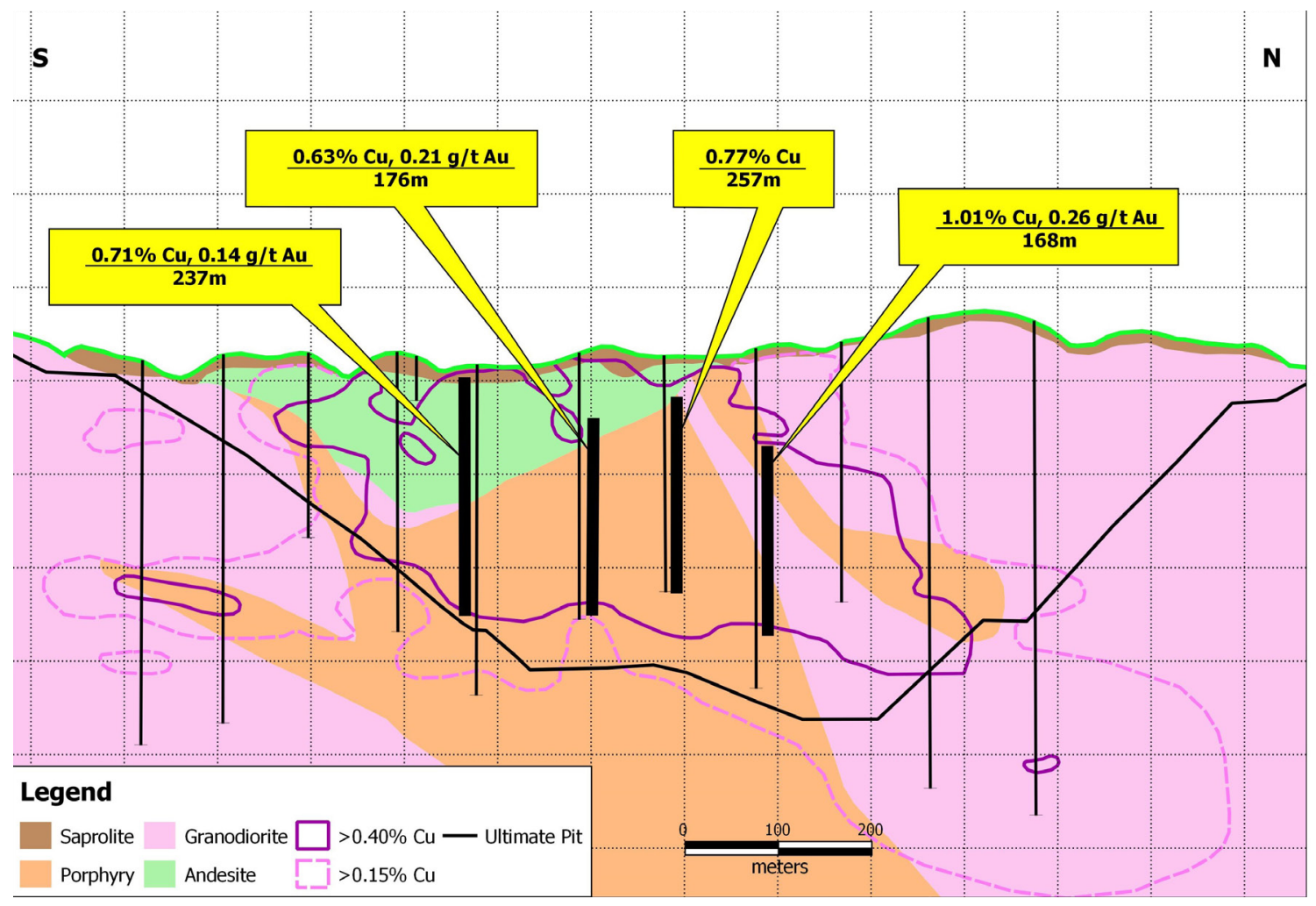

Figure 16 Cross section of the Botija porphyry deposit showing the inclined porphyry intrusion (modified from an Inmet presentation, 2012).

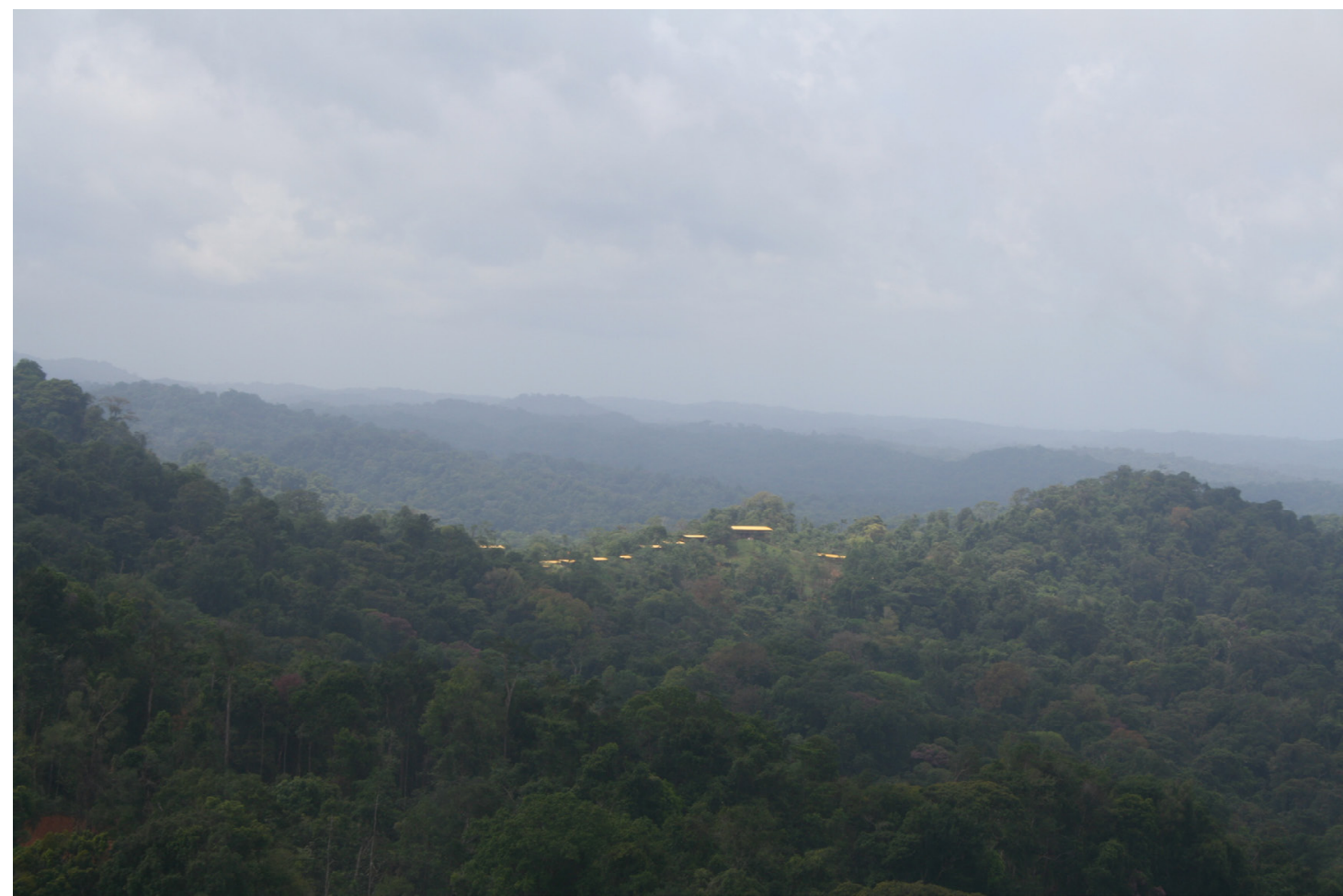

Figure 17 The Cobre Panama deposit during exploration in 2007, looking west at the Colina exploration camp. The Botija deposit lies below the helicopter, and the Colina deposit lies beyond the ridge (photo S. Redwood). 
are more typical of porphyry deposits (Figure 16). The upper, epithermal levels of the hydrothermal systems were mostly removed by erosion but relics are preserved in three deposits. The present incised terrain exposes the high temperature alteration and related sulphide-bearing stockwork of all but one of the known deposits, with a low strip ratio of about 1:1 of ore to waste. The Balboa deposit does not outcrop and was discovered by drilling a low resistivity anomaly in 2010. It is interpreted that the low angle geometry is a primary feature formed by emplacement of a multiphase porphyritic dyke swarm along a pre-existing moderately to shallowly-inclined reverse fault zone (Ireland et al., 2014). In addition, several of the deposits are cut off at depth by a late mineral porphyry intrusion (Botija, Colina, Brazo, Botija Abajo, part of Valle Grande), while others are underlain by andesitic wall-rock. Early vein geometries locally mimic the overall dyke orientation although later hydrothermal and magmatic stages are more steeply dipping. These relationships imply that mineralization mostly occurred during compression, with a synlate-mineral switch to transpressional conditions. Post-mineral extensional faulting had the effect of arranging the main stage stockworks within a narrow range of elevation (Ireland et al., 2014). The Balboa, Brazo and Valle Grande deposits appear to have upright porphyry centers at depth or down plunge, which may have been the feeders to the low angle bodies.

An alternative tilting model was proposed by Sepp and Dilles (2018) based on a study of vein orientations at Botija and three-dimensional modeling. They concluded that the seven porphyry deposits were likely produced by normal faulting that dismembered and tilted two or more originally upright porphyry copper deposits. Their measurement of the dip of veins at Botija deposit suggested $40^{\circ}$ of south-southeast tilting after mineralization, assuming that they formed vertically. Restoration of the modeled $\mathrm{Cu}-\mathrm{Mo}$ grade contours along identified faults removes $10^{\circ}$ to $15^{\circ}$ of tilting to the southeast and produces a single ore shell with an inverted cup-shaped geometry typical of many porphyry copper deposits. However, restoring the ore shells to an upright geometry requires removal of an additional $25^{\circ}$ to $30^{\circ}$ of southeast tilting that they cannot account for and infer was produced by earlier generations of SW-striking and NW-dipping faults (Sepp and Dilles, 2018).

\subsubsection{PALMILLA PORPHYRT Cu-Au PROSPECT}

The Palmilla porphyry $\mathrm{Cu}-\mathrm{Au}$ prospect, located northwest of Cobre Panama, was discovered during the follow up phase of the UN regional exploration program in 1969. It was drilled by Adrian Resources and Madison Enterprises Corporation in 1993-1996, and by Petaquilla Minerals in 2011-2013, with a total of 13,136 m of diamond drilling in 60 holes. This gave a measured and indicated resource of $27 \mathrm{Mt}$ at $0.24 \% \mathrm{Cu}, 0.59 \mathrm{~g} / \mathrm{t}$ $\mathrm{Au}$ and $0.87 \mathrm{~g} / \mathrm{t} \mathrm{Ag}$, and an inferred resource of $11 \mathrm{Mt}$ at $0.22 \% \mathrm{Cu}, 0.40 \mathrm{~g} / \mathrm{t} \mathrm{Au}$ and $0.67 \mathrm{~g} / \mathrm{t} \mathrm{Ag}$, at a cut-off $0.35 \mathrm{~g} / \mathrm{t}$ Au equivalent (Camus, 2013).

The geology is hornblende granodiorite intruding andesitic lavas and tuffaceous turbidites. Alteration of the volcano-sedimentary rocks is propylitic (chlorite, epidote, carbonate, silica) with pyrite and magnetite. The best mineralization is in biotite hornfels at the intrusion contact which has quartz-magnetite veinlets with chalcopyrite and bornite. Weak biotite hornfels (or potassic alteration) is described in the intrusions. Mineralization is described as porphyry style copper mineralization overprinted by low sulphidation epithermal gold (Camus, 2013), resulting in a gold-rich porphyry.

\subsubsection{MOLEJON LOW SULPHIDATION EPITHERMAL AU DEPOSIT}

The Molejon deposit is a low sulphidation epithermal vein located about $2 \mathrm{~km}$ southwest of the Brazo porphyry copper deposit. It was described by Speidel et al. (2001) and in NI 43-101 reports by Wahl (2005), Muller (2007) and Archibald et al. (2011, 2012). It was discovered by Minnova (Inmet Mining) in 1992 in the course of district-scale exploration around Petaquilla using regional rock geochemistry, and was drilled by Adrian Resources in 1994-1995. Petaquilla Minerals Ltd. (ex-Adrian Resources) mined the deposit by 
open pit from 2009-2014 to produce 7.20 metric tons of gold with byproduct silver. The ore was processed by grinding and gold was recovered in carbon-in-pulp plant with 2,200 tpd capacity, later expanded to 3,500 tpd. Low grade material containing 4.73 metric tons of gold was stockpiled for a planned heap leach plant. The measured and indicated resources in 2012 were $31.6 \mathrm{Mt}$ at 0.80 $\mathrm{g} / \mathrm{t} \mathrm{Au}(25.42 \mathrm{t})$ and $1.74 \mathrm{~g} / \mathrm{t} \mathrm{Ag}(43.54 \mathrm{t})$ at a cutoff of $0.2 \mathrm{~g} / \mathrm{t} \mathrm{Au}$, plus inferred resources of 3.3 Mt at $0.35 \mathrm{~g} / \mathrm{t} \mathrm{Au}(1.16 \mathrm{t})$ and $1.05 \mathrm{~g} / \mathrm{t} \mathrm{Ag}(3.47$ t) (Archibald et al., 2012). Proven and probable reserves were $15.3 \mathrm{Mt}$ at $1.31 \mathrm{~g} / \mathrm{t} \mathrm{Au}(20.00 \mathrm{t})$ and $2.1 \mathrm{~g} / \mathrm{t} \mathrm{Ag} \mathrm{(31.10} \mathrm{t),} \mathrm{at} \mathrm{a} \mathrm{cut-off} \mathrm{of} 0.2 \mathrm{~g} / \mathrm{t} \mathrm{Au}$ (Archibald et al., 2012).

The deposit is hosted by a sequence of massive and fragmental andesitic volcanic rocks including flow breccias, lapilli tuffs and lavas which are cut by feldspar-quartz porphyries forming sills and phacoliths. These rocks are cut by several steeply-dipping, NE-striking faults. Gold occurs in multi-phase quartz-carbonate veins and vein breccias with chalcedony and to a lesser extent in altered intrusions or in quartz stockworks. The veins and breccias exhibit open space filling textures such as colloform banding, cockscomb and cockade structures. The vein zones strike NE and dip shallowly NW, conformable with stratigraphy (Figure 18). Several subsidiary structures with a steeper dip and more northerly strike are also present, often in areas of higher gold grade.
Visible sulfides are rare, but high grades are often obtained in grey quartz bands, where the colour may be due to very fine sulfides. Free gold occurs as minute crystals of 1-15 $\mu \mathrm{m}$ of gold or electrum in quartz. Silver occurs in electrum and possible tetrahedrite (Speidel et al., 2001; Wahl, 2005).

Alteration is characterized by a chlorite-sericite-carbonate (phyllic) assemblage in the volcanic rocks, with sericite and silicification in the intrusive rocks. The footwall has strong propylitic alteration (epidote-chlorite-hematite), containing up to 15\% pervasive epidote (Speidel et al., 2001). Mineralization is characterized by the presence of $\mathrm{Au}$ and $\mathrm{Ag}$ only, with pathfinder elements only very weakly anomalous (As and Sb mostly $<10 \mathrm{ppm}$ ) or below detection $(\mathrm{Hg}<0.01 \mathrm{ppm})$. $\mathrm{Cu}$ and $\mathrm{Mo}$ ar only found locally in trace amounts. $\mathrm{Au} / \mathrm{Ag}$ ratios are highly variable from $1: 2$ to $2: 1$. The highest $\mathrm{Au}$ grades are found in the upper zone in quartz breccias. There is strong saprolitic oxidation to kaolinite and hematite to a depth of about $30 \mathrm{~m}$ (Speidel et al., 2001; Wahl, 2005; Muller, 2007).

There are two orebodies, the Main and Northwest Zones. The Main Zone, which outcrops on Loma Blanca, is $1,100 \mathrm{~m}$ long NE with 450 $\mathrm{m}$ dip length and width up to $75 \mathrm{~m}$, and dips at $30^{\circ} \mathrm{NW}$ becoming sub-horizontal at depth. The Northwest Zone sits above the Main Zone and is sub-horizontal to SE-dipping and joins with the Main Zone (Archibald et al., 2012). Molejon is a typical, vein-type, low sulphidation epithermal

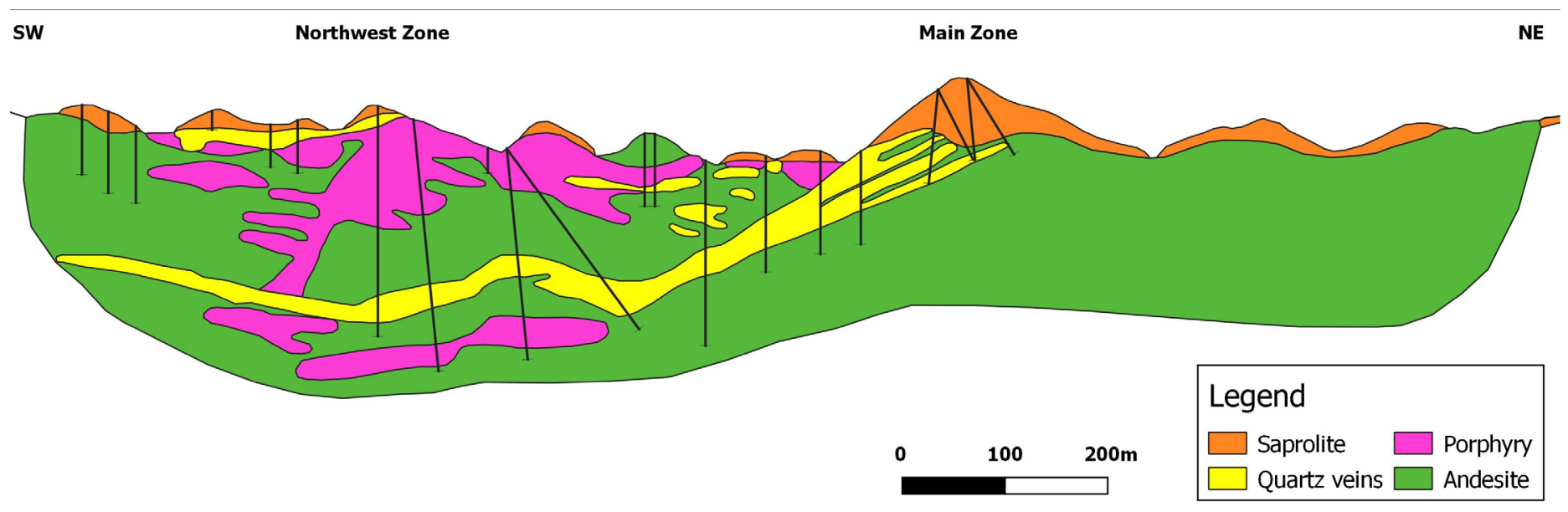

Figure 18 Cross section of the Molejon deposit looking NW (modified from Archibald et al., 2012). 
gold-silver deposit. The low to sub-horizontal dip, stacked veins, vein breccias and wall rock breccias mimic the geometry of the porphyry sill-phacolith and indicates a low angle structural control, which may be thrust flats and ramps. However, low sulphidation epithermal deposits are associated with extensional tectonics (John, 2001; Sillitoe, 2002). The relationship to the Cobre Panama porphyry $\mathrm{Cu}$ mineralization is not known but they share a similar structural control. A NE-trending fault connects Molejon with the Brazo and Botija Abajo porphyry deposits. The simplest explanation is that the epithermal mineralization is contemporary with and peripheral to the cluster of porphyry deposits. However, the epithermal vein formed at a much shallower crustal level and it may be a significantly younger event than the porphyries.

\subsection{VERAGUAS EPITHERMAL Au BELT}

\subsubsection{SANTA FÉ EPITHERMAL Au DISTRICT}

The Veraguas gold belt in the Santa Fé district, located in the foothills and the Caribbean lowlands of northern Veraguas, is about $30 \mathrm{~km}$ long trending ENE parallel to the coast by $4 \mathrm{~km}$ wide, with about ten mined vein deposits and widespread placer gold on the Rivers Santiago, Concepción, Veraguas and Belén. It was evaluated by UNDP in the late 1960s (Wleklinski, 1969). The deposits were mined by indigenous miners and by the Spaniards. The most important mine was Cocuyo on the River Santiago which was mined from 1559-1589 and produced about 9 metric tons of gold from alluvial and quartz vein deposits, the most important being the Margaja vein (Castillero Calvo, 1967a, 1967b; Wleklinski, 1969). Quartzgold veins, presumably epithermal, were described at Mina del Rey (or Palenque) on the River Belén by Taylor (1852).

\subsubsection{MARGAJA EPITHERMAL Au DEPOSIT}

The best known vein deposit in the belt is the Margaja Mine in the upper part of the Cocuyo gold placer district of the River Santiago. A quartz vein trending $\mathrm{N} 75^{\circ} \mathrm{E}$ and dipping $65^{\circ} \mathrm{S}$ is hosted by basalt. It was mined by Veraguas Mines Ltd. on lease from the Panama Corporation (Canada) Ltd in 1933-1936 and produced 30,094 ounces (936 kg) of gold, 20,269 ounces (630 kg) of silver and 427,169 lb (194 t) of copper from 28,923 tons (26,239 metric tons) of ore. The mine had five levels up to $177 \mathrm{~m}$ long. Ore shoots graded more than $1,000 \mathrm{~g} / \mathrm{t} \mathrm{Au}$ with a maximum sample grade of 2,722 $\mathrm{g} / \mathrm{t}$ over $2.5 \mathrm{~m}$ vein width (1934 mine plan). It was evaluated by UNDP in 1967 and 18 check samples gave an average grade of $130.0 \mathrm{~g} / \mathrm{t}$ over $0.80 \mathrm{~m}$ vein width (Hull, 1940; Wleklinski, 1969).

The host rocks are regionally mapped as Miocene Cañazas Formation with small intrusions of the Petaquilla suite of Oligocene age (DGRM, 1991) although the original map from the Azuero Mining Project shows the volcanic rocks to be of undifferentiated Tertiary age (del Giudice and Recchi, 1969). The deposit is $40 \mathrm{~km}$ west of the Molejon epithermal vein deposit in the Petaquilla $\mathrm{Cu}-\mathrm{Au}$ belt, and it is probable that the Santa Fé Au belt is a continuation of this belt with late Eocene volcanic rocks and lower Oligocene plutons.

\section{Late Arc: Miocene-Quaternary porphyry and epithermal deposits}

The Miocene volcanic arc (18-5 Ma) forms the Central Cordillera of western Panama, while the Pliocene-Quaternary volcanic arc (5-0 Ma) is superimposed on it and forms the large active stratovolcanos of El Valle, La Yeguada and El Barú. Epithermal Au mineralization is related to these arcs at El Valle Volcano and the Veraguas Gold Belt, while porphyry $\mathrm{Cu}$ deposits occur in the western Central Cordillera at Cerro Colorado and Cerro Chorcha.

\subsection{EPITHERMAL AU DEPOSITS RELATED TO EL VALLE VOLGANO}

\subsubsection{VOLCANIC EVOLUTION}

Several epithermal gold deposits and prospects occur in the El Valle volcano which is located at 
the eastern end of the Miocene to Quaternary volcanic arc of western Panama. There is no known mineralization related to the La Yeguada and Barú Quaternary stratovolcanos.

The El Valle volcano is a $60 \mathrm{~km}$ diameter stratovolcano with an altitude of $1,185 \mathrm{~m}$ with multiple, overlapping calderas including a young summit caldera and resurgent domes. The older part of the volcano is formed of andesitic to basaltic lavas, tuffs, breccias, dikes and sills of the upper Miocene Tucué Formation, part of the Cañazas Group. This is overlain by felsic lavas, ignimbrites and pyroclastic rocks of the La Yeguada, El Valle and Rio Hato Formations, with numerous minor volcanic centers marked by plugs and domes (SGI, 1991a; DGRM, 1991).

Radiometric dating by K-Ar and Ar-Ar has defined an Old Group of volcanic rocks of 10-5 $\mathrm{Ma}$, followed by quiescence for about 4 to 5 My, then a Young Group of ignimbrites, lavas and domes of 1.55 to $0.03 \mathrm{Ma}$ (Defant et al., 1991a,1991b; Hidalgo et al., 201 1; Wegner et al., 2011). The summit caldera formed between 56 and $31.8 \mathrm{ka}$ (Hidalgo et al., 2011) and is filled with $>90 \mathrm{~m}$ thickness of lake sediments, the El Valle Unit, with ${ }^{14} \mathrm{C}$ ages between 31,850 $\pm 1,800 \mathrm{yr} \mathrm{BP}$ and 2,370 $\pm 150 \mathrm{yr} \mathrm{BP}$ (Bush and Colvinaux, 1990). Both the Old and Young Groups of volcanic rocks are calc-alkaline, while the Young Group has adakite-like geochemistry (Defant et al., 1991a; Hidalgo et al., 2011).

Swedish Geological International (SGI), funded by the Interamerican Development Bank, carried out a mineral reconnaissance program in the El Valle region in 1988-1990 (SGI, 1991a,1991b). This included geological mapping, regional stream sediment geochemistry, rock geochemistry and, at Capira, a limited program of trenching and diamond drilling. Gold mineralization is known in four areas in the El Valle volcano: 1) Capira - low sulphidation epithermal quartz-gold veins were mined in the Campana and Trinidad mines; 2) Cacao - low sulphidation epithermal quartz-gold veins were mined in the La Florida mine; 3) Cerro Lloron high sulphidation gold prospect related to vuggy silica alteration; and 4) La Concepción mine - an epithermal gold vein near La Pintada. The mineralization at Capira, Cacao and La Concepción is hosted by volcanic rocks of the upper Miocene Tucué Formation, part of the Old Group, while Cerro Lloron is hosted by the Young Group.

\subsubsection{CAPIRA LOW SULPHIDATION EPITHERMAL Au DEPOSIT}

The Capira gold district comprises a series of low sulphidation epithermal quartz veins in a $15 \mathrm{~km}$ long zone trending NE between San Martin (El Espino) and Cerro Campana with a width of 10 $\mathrm{km}$ (Figure 19). The total vein length is more than $30 \mathrm{~km}$. Gold was discovered in 1703 and mining was carried out until the $20^{\text {th }}$ century. Swedish Geological International carried out exploration in 1988-1990 (SGI, 1991a). It identified 13 veins with grades up to $18 \mathrm{~g} / \mathrm{t}$ Au over $1.2 \mathrm{~m}$ in a zone $1,500 \mathrm{~m}$ long with zones of alteration up to 30 $\mathrm{m}$ wide. They evaluated 5 of the veins in detail (Brenda, Flor, Dani, Madrid and Suecia veins), with trenching and 7 diamond drill holes (641.5 $\mathrm{m})$ on the Brenda and Flor veins, and a best intersection of $1.2 \mathrm{~m}$ at $2.3 \mathrm{~g} / \mathrm{t} \mathrm{Au}$. Capira was subsequently explored by Capira Dorada S. A. in 1991-2010s.

The geology of the Capira district comprises volcanic rocks of the upper Miocene Tucué Formation including subaerial andesite/basalt breccias, tuffs, lavas, dikes and sills, and several volcanic centers or plugs at Cerro Viejo, Loma Rica, Cerro Trinidad, Cerro Valloli, Cerro Campana, Cerro Pan de Azúcar and Loma Peñon. There are zones of pervasive argillic, silicic and propylitic alteration at Cerro Cermeño, Cerro Campana, Cerro Trinidad and Cerro El Viejo. (SGI, 1991a). The veins are bounded by two NE-trending faults, and the principal vein trend is NNE, with secondary N-S and E-W trends. The vein textures include hydrothermal breccias, cockscomb quartz, drusy quartz and granular quartz. 


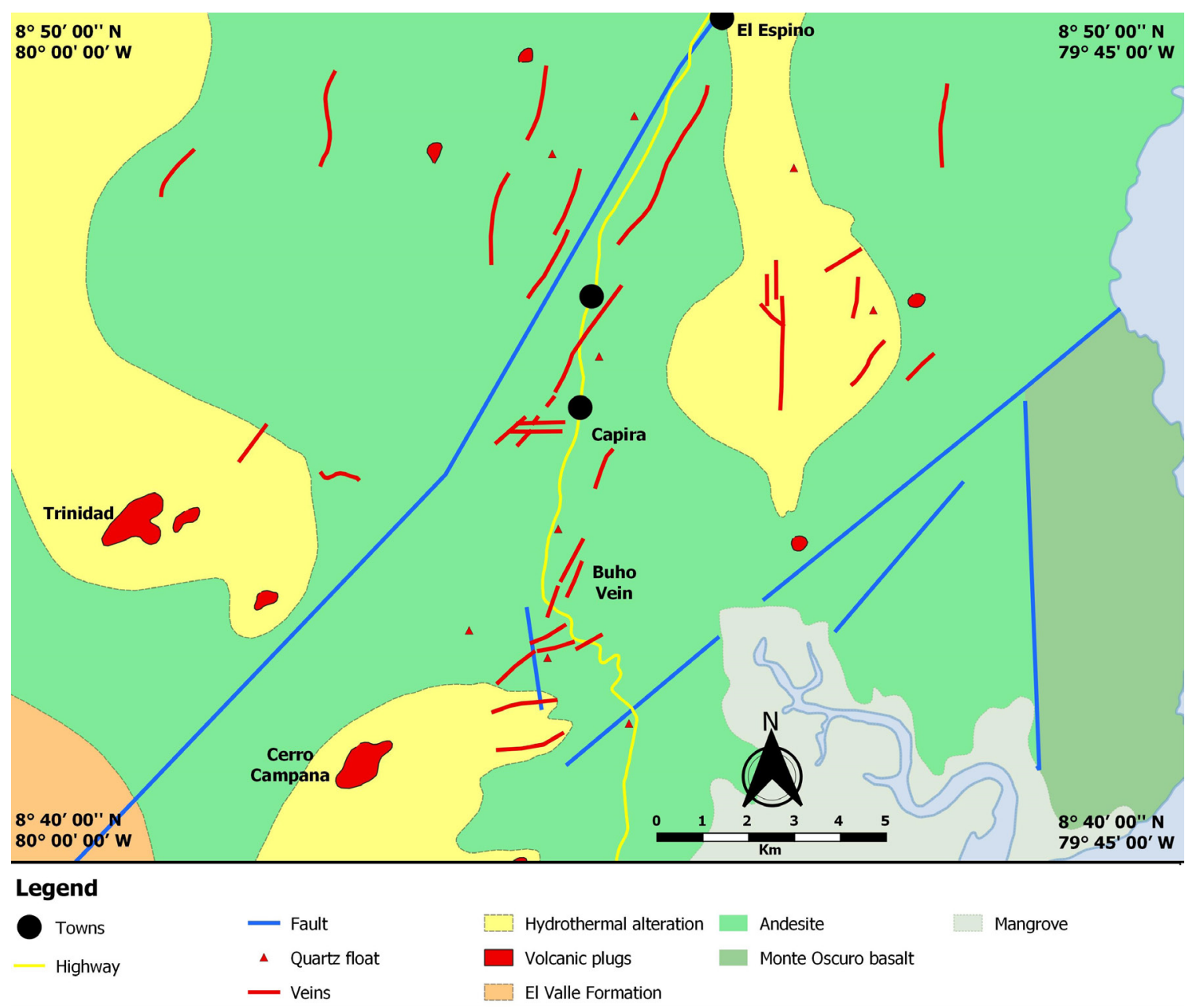

Figure 19 Geological map of the Capira epithermal gold deposit (modified from SGI, 1991a).

\subsubsection{CACAO (LA FLORIDA) LOW SULPHIDATION EPITHERMAL A PROSPECT}

The gold mineralization at Cacao was mined at La Florida by the Panama Corporation (Canada) Ltd in the 1930-1940s, and the deposit was evaluated by the regional geochemical survey by SGI in 1988-1990 which identified a large zone of alteration with quartz veinlets, and gave up to $0.1 \mathrm{~g} / \mathrm{t} \mathrm{Au}$ in chip samples of veinlets (SGI, 1991a). Follow up exploration by SGI included 89 chip samples with values of 0.02 to $2.21 \mathrm{~g} / \mathrm{t}$ $\mathrm{Au}$. Exploration of Cacao was carried out in the 1990s-2010s by Capira Dorada, S. A., Panama.

The geology comprises fragmentary andesites of the Tucué Formation, andesitic subvolcanic intrusions, and andesite and dacite tuffs of the Río Hato Formation. Regionally the zone is located at the intersection of E-W, N-S and NW-SE structures. Locally the zone is between two N-S faults, and structures mapped from air photos are arcuate structures, NE, NW and NNE faults. Alteration is described as silicification and propylitic alteration, with chlorite, sericite, quartz, some epidote and disseminated pyrite. The vein trends are N-S and $\mathrm{N} 60^{\circ} \mathrm{E}$. The veins are crystalline and milky quartz, and chalcedony, and there are breccias with pyrite and arsenopyrite.

Observations by the author showed numerous quartz veins with visible gold, colloform banding, cockscomb textures, and bladed quartz pseudomorphs of calcite, textures which are typical of low sulphidation epithermal quartz veins. 
9.1.4. CERRO LLORON HIGH SULPHIDATION EPITHERMAL Au PROSPECT

Cerro Lloron (or Cerro Pelado) is a high sulphidation epithermal gold prospect hosted by vuggy silica alteration in welded tuffs near the NE margin of the El Valle summit caldera. Gold mineralization was discovered by stream sediment anomalies in a regional exploration program carried out by Swedish Geological International AB in 1988-1990 (SGI, 1991a, 1991b). It was explored by Rayrock Resources Inc. in 1995-1997 which drilled 6 holes for $848 \mathrm{~m}$ in 1996. The best results were $142 \mathrm{~m}$ at $0.5 \mathrm{~g} / \mathrm{t} \mathrm{Au}$ and $50 \mathrm{~m}$ at $0.93 \mathrm{~g} / \mathrm{t} \mathrm{Au}$ in vuggy silica.

Cerro Lloron is located about $2 \mathrm{~km} \mathrm{NE}$ of the margin of the El Valle summit caldera on a NNW-trending structure which may be an outer or older ring fracture. Mineralization must be late Quaternary in age given the young host rocks. Gold mineralization occurs in vuggy silica altered ignimbrite which outcrops in a $345^{\circ}$-trending cliff called Muro Dorado (Golden Wall). Alteration may either be structurally controlled or stratiform.

\subsubsection{CONCEPCIÓN LOW SULPHIDATION EPITHERMAL Au DEPOSIT}

The Concepción mine is located $15 \mathrm{~km} \mathrm{~N}$ of Penonomé on the west side of the El Valle volcano. There is a $57 \mathrm{~m}$ long adit trending $\mathrm{N} 20^{\circ} \mathrm{E}$ which is collapsed. SGI (1991a) reported an altered breccia at the entrance and dumps of argillic altered tuffs with free gold, with grades up to $1.13 \mathrm{~g} / \mathrm{t} \mathrm{Au}$. The mineralization is hosted by volcanic rocks of the upper Miocene Tucué Formation.

\subsection{GENTRAL VERAGUAS GOLD BELT}

\subsubsection{INTRODUCTION}

The Central Veraguas Gold Belt is a belt of low sulphidation gold deposits of Miocene age with a length of about $40 \mathrm{~km} \mathrm{E-W}$ by $20 \mathrm{~km}$ wide (Wleklinski, 1969; Nelson, 2001; Folk, 2004c). It is usually called the Veraguas Gold Belt but it has been given the prefix Central to distinuguish it from the gold belt in northern Veraguas, which has historical priority for the name. There are no other known gold deposits east of Los Hatillos for 60 km until La Concepción.

The host rocks are subaerial volcanic arc rocks of basaltic to rhyolitic composition of the middle Miocene Cañazas Formation of calc-alkaline to high-K calc-alkaline suite. This has been dated by $\mathrm{K}-\mathrm{Ar}$ at $17.5 \pm 0.6 \mathrm{Ma}$ to $16.6 \pm 0.6 \mathrm{Ma}$ (Wleklinski, 1969 and Nelson, 2001). Volcanic landforms and structures are common including craters, volcanic centers, caldera ring fractures and domes, indicating a shallow erosional level. The district has numerous epithermal gold deposits and prospects which have been mined since the mining town of San Francisco was founded in about 1620. The district was evaluated by UNDP in 1967-1969 (Wleklinski, 1969). In the 1980s and 1990s, several companies carried out exploration and two gold mines were put into production at Remance (1990-1998) and Santa Rosa (19951999). Exploration has declined since then, but the Santa Rosa mine is planned to restart in 2020. The geology and mineral deposits of the district were described by Nelson and Ganoza (1999) and Nelson (2001) who emphasized the relationship of gold mineralization to volcanic domes and their pyroclastic aprons of volcanic breccias, block and tuff deposits, and lithic tuffs. These are often interfingered with thinly bedded, black carbonaceous sediments deposited in an anoxic, subaqueous environment in lagoons, and sinter is described at Remance.

Many of the gold deposits are hosted by banded quartz veins with typical shallow level, low sulphidation epithermal features such as bladed quartz, cockscomb textures, colloform banding, chalcedony, jasper, adularia and low sulphide content (e.g. Remance, Boca de Higui, San Pedrito), although one deposit has high base metal sulphides (Los Hatillos). Mineralization at the Santa Rosa deposit is disseminated in phreatic or phreatomagmatic breccias, crackle breccias and stockwork veinlets. All of the deposits have a regional structural control on the mineralization which is N-S to NW, indicating a relationship between low sulphidation 
epithermal mineralization and extension, as is typical of such systems (e.g. John, 2001; Sillitoe, 2002 and Simmons et al., 2005).

\subsubsection{LOS HATILLOS INTERMEDIATE SULPHIDATION EPITHERMAL A U DEPOSIT}

The Los Hatillos veins were first worked by the Spaniards in about 1620. The mine was developed by the Panama Corporation Ltd. in 1926-1932 which discovered the La Blanca-La Cuelga vein and defined a reserve of 11,000 tons grading 14.0 $\mathrm{g} / \mathrm{t} \mathrm{Au}, 3.1 \% \mathrm{~Pb}$ and $4.3 \% \mathrm{Zn}$. The other important veins are Peñon, Los Angeles and Blow. The deposit was evaluated by UNDP in 1967-1969 which reported reserves of 30,000 tons grading $12.5 \mathrm{~g} / \mathrm{t} \mathrm{Au}, 21.6 \mathrm{~g} / \mathrm{t} \mathrm{Ag}, 2.49 \% \mathrm{~Pb}, 3.85 \% \mathrm{Zn}$ and $0.14 \% \mathrm{Cu}$ on the La Blanca Vein (Wleklinski, 1969 and Folk, 2004c). The gold and base metal mineralization is hosted by N-S trending quartz veins in andesite with quartz-sericite-pyrite wall rock alteration, and contain sphalerite, galena and trace chalcopyrite (Folk, 2004c).

\subsubsection{REMANCE LOW SULPHIDATION EPITHERMAL Au} DEPOSIT

The Remance low sulphidation epithermal gold veins have been mined intermittently since the mid $18^{\text {th }}$ century with total known gold production of about 3.72 metric tons. The mine was last operated from 1990-1998 by Minera Remance S. A. which produced about 2.74 metric tons of gold at a head grade of $6.0 \mathrm{~g} / \mathrm{t}$ (Figure 20).

Reserves in 1993 were given as 500,000 metric tons at $6.0 \mathrm{~g} / \mathrm{t} \mathrm{Au}$ (3.00 t gold). Several companies carried out exploration drilling for bulk mineable targets as well as veins since the 1990s. Grades of drill intersections vary from $<1$ to $68.5 \mathrm{~g} / \mathrm{t}$ Au over true widths of 0.17 to $6.4 \mathrm{~m}$, with highlights of $0.85 \mathrm{~m}$ at $68.5 \mathrm{~g} / \mathrm{t}, 0.6 \mathrm{~m}$ at $37.3 \mathrm{~g} / \mathrm{t}, 1.1 \mathrm{~m}$ at 18.7 $\mathrm{g} / \mathrm{t}, 1.9 \mathrm{~m}$ at $16.9 \mathrm{~g} / \mathrm{t}, 2.3 \mathrm{~m}$ at $13.4 \mathrm{~g} / \mathrm{t}$, and 2.3 $\mathrm{m}$ at $12.6 \mathrm{~g} / \mathrm{t}$. Potentially bulk-mineable targets are shown by intersections of $14.2 \mathrm{~m}$ at $3.9 \mathrm{~g} / \mathrm{t}, 44.4$ $\mathrm{m}$ at $4.15 \mathrm{~g} / \mathrm{t}, 34.0 \mathrm{~m}$ at $2.2 \mathrm{~g} / \mathrm{t}$, and $29.7 \mathrm{~m}$ at 1.8 $\mathrm{g} / \mathrm{t}$ (Pacific Rim press release, 20 August 2010).

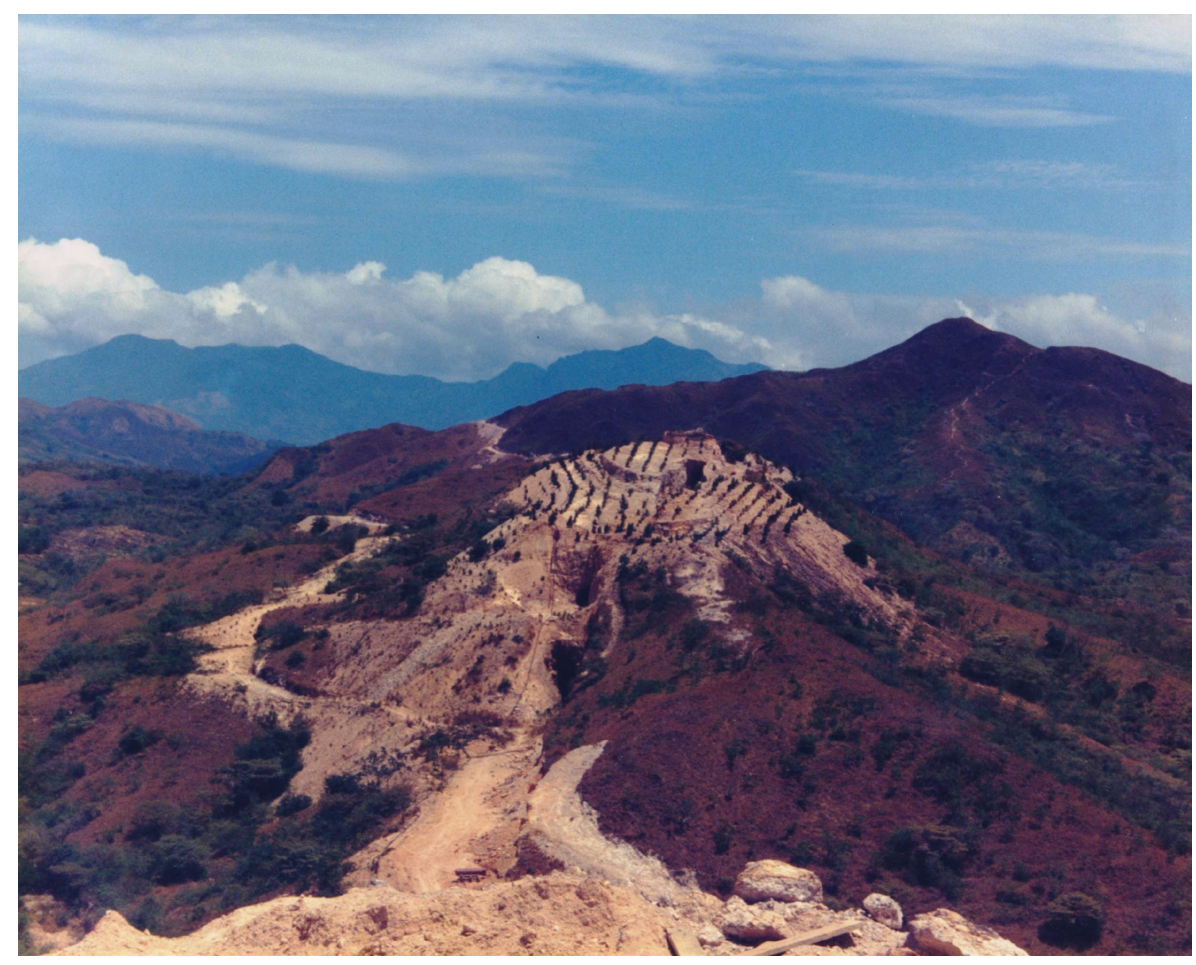

Figure 20 The Principal Vein of the Remance mine looking north when it was in operation in 1994. Note the reforestation on Cerro Bigui which is now large trees. (Photo: S. Redwood). 
The geology was described briefly by Nelson (2001) as several basaltic andesite to dacite flow-domes surrounded by pyroclastic deposits including volcanic breccias, lapilli tuffs, crystal tuffs and andesite flows. Mineralization is hosted by steep quartz veins in a $3.0 \mathrm{~km}$ long system over $1.0 \mathrm{~km}$ width with the main vein trend N15 $\mathrm{W}$ (Principal, Santa Rosa and Consuelo veins), a secondary vein trend of N20$45^{\circ} \mathrm{E}$ (Huati, Baltazar, Dorita, San Fernando and Esperanza veins), and late NE-trending faults causing left-lateral offset of the Principal Vein by up to $50 \mathrm{~m}$ (Figure 21). The width of the Principal Vein is $0.6-3.0 \mathrm{~m}$ with zones up

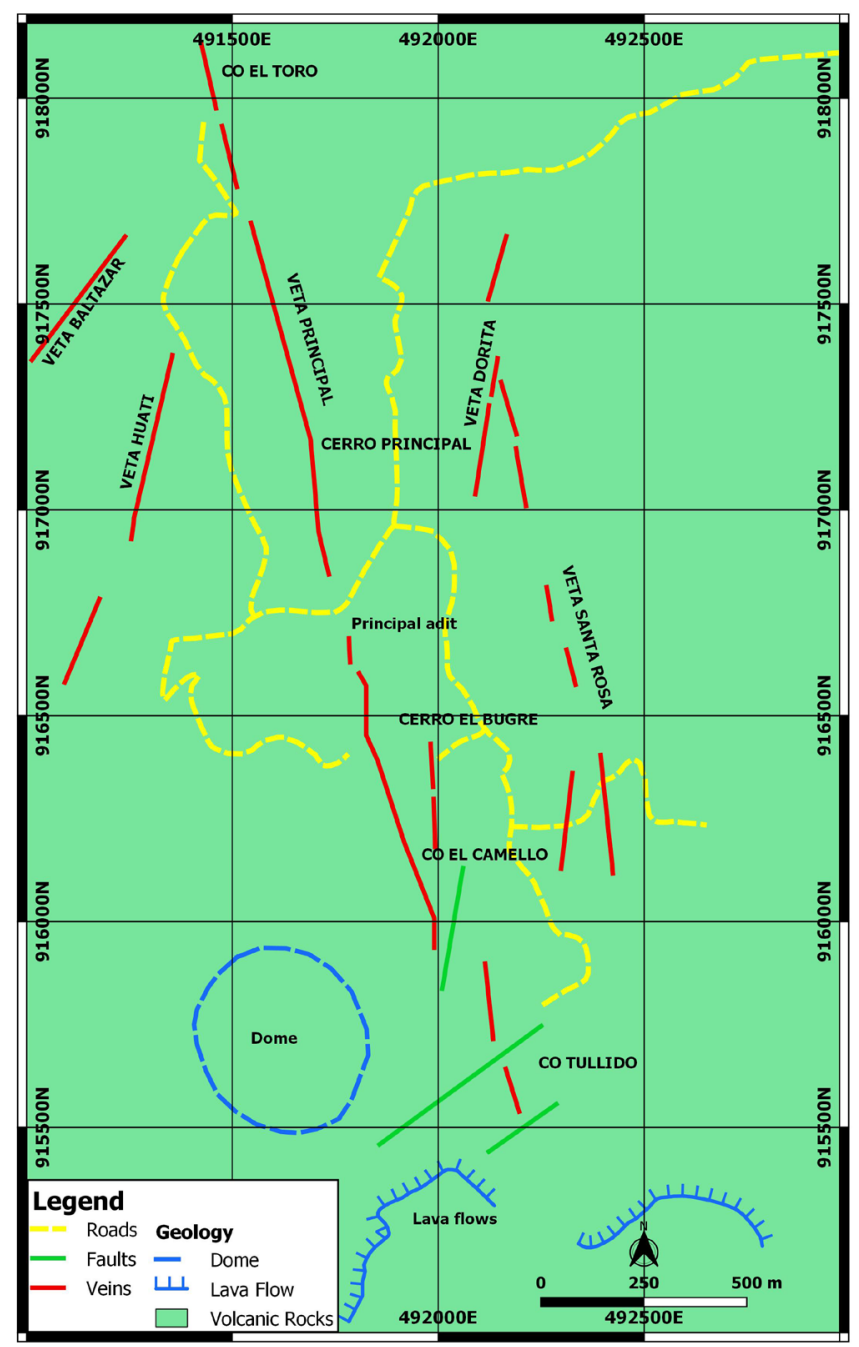

Figure 21 Geological map of the Remance gold deposit (map by S. Redwood). to $5.0 \mathrm{~m}$. It is interpreted as a NNW-trending dextral Riedel strike slip fault system, with the main veins being $\mathrm{R} 1$ shear fractures and the secondary veins conjugate R2 fractures. The wall rock alteration is argillic. The quartz vein textures include granular, sucrose, drusy, bladed quartz after calcite, bladed chalcedony, colloform banding, crustiform banding, chalcedony and jasperoid, with hydrothermal vein breccias cemented by chalcedony, black quartz or open space. The veins have very low sulphide content which is generally $1-2 \%$ pyrite, with higher amounts of $5-10 \%$ fine pyrite in black breccias and $10-20 \%$ in jasperoid veins.

Other minor sulfides described by Nelson (2001) are arsenopyrite, chalcopyrite, sphalerite and galena. There is oxidation to a depth of 130-140 m with jarosite and hematite. A suite of vein samples showed that grades up to $6.71 \mathrm{~g} / \mathrm{t} \mathrm{Au}$ and $234.9 \mathrm{~g} / \mathrm{t} \mathrm{Ag}$ are accompanied by high $\mathrm{As}(3,600 \mathrm{ppm})$ and $\mathrm{Hg}$ (20 $\mathrm{ppm}$ ) and low $\mathrm{Sb}, \mathrm{Cu}, \mathrm{Pb}$ and $\mathrm{Zn}$ (Nelson, 2001). Remance is a typical low sulphidation epithermal vein system with a regional structural vein control, with a shallow level of the system shown by low temperature silica minerals, vein textures and high mercury values.

\subsubsection{BOCA DE HIGUI LOW SULPHIDATION EPITHERMAL A $\mathrm{PROSPECT}$}

Boca de Higui is a cluster of NNW-trending quartz veins up to $2 \mathrm{~km}$ long and $2 \mathrm{~m}$ wide which have the same strike as the main veins at Remance, located about $5 \mathrm{~km}$ to the southeast. The veins are hosted by propylitically altered andesite flows, volcanic breccias, lapilli tuffs and thinly bedded carbonaceous sediments. Open cuts and stone mortars indicate historical production from the Vasco mine. It was explored by Freeport in 1985-1989 and was drilled with 24 holes by Greenstone in 1994 (Nelson, 2001; Folk, 2004c). 
9.2.5. SAN PEDRITO LOW SULPHIDATION EPITHERMAL Au PROSPECT

The San Pedrito prospect is located between the Remance and Santa Rosa gold deposits. There are early Spanish or pre-Columbian open-cut workings. The Panama Corporation explored it in 1927-1932 with adits and trenches, and an attempt was made to mine it in 1938. Freeport explored in 1985-1989 and drilled 5 holes in 1988 at Las Minitas to test a series of NNE-trending veins in propylitically altered andesite, and at Cerro Cristal. The geology comprises two rhyodacite domes with tuff aprons. The western one has argillic alteration with auriferous quartz veins, while the eastern dome is not altered (Wleklinski, 1969; Nelson, 2001; Folk, 2004c).

\subsubsection{SANTA ROSA (ALTO DE LA MINA) BRECCIA-HOSTED LOW SULPHIDATION EPITHERMAL Au DEPOSIT}

The Santa Rosa and Alto de la Mina gold deposits near Cañazas are breccia-hosted, low sulphidation epithermal systems. The geology was described by White (1994), Fernández et al. (1997), Byington and Russell (2001) and Nelson (2001).

The deposits have been mined intermittently since the late 1800s. Greenstone Resources Ltd. mined about 3.70 $\mathrm{t}$ of gold from 1995-1999 in an open-pit, heap leach operation (Figure 22).

The project was reactivated in 2009 by private company Veragold Mining Company Inc., Panama. It estimated resources in 2016 of $21.0 \mathrm{Mt}$ at $1.16 \mathrm{~g} / \mathrm{t} \mathrm{Au}(24.26 \mathrm{t})$ measured and indicated plus $3.4 \mathrm{Mt}$ at $1.80 \mathrm{~g} / \mathrm{t}(6.22 \mathrm{t})$ inferred in three deposits, ADLM, Santa Rosa and Cerro Otero, in addition to $5.0 \mathrm{Mt}$ at 0.75 $\mathrm{g} / \mathrm{t} \mathrm{Au} \mathrm{(3.73)} \mathrm{on} \mathrm{the} \mathrm{old} \mathrm{leach} \mathrm{pads} \mathrm{(Veragold}$ website). The company plans to start production 2020 with a 500 tpd plant to produce about 250 $\mathrm{kg}$ of gold per year, and to ramp the plant up to 6,500 tpd in 2022 to produce about $3,173 \mathrm{~kg}$ of gold per year.
Mineralization is hosted by volcaniclastic and subvolcanic rocks and breccias of the Cañazas Formation. The lowest rocks are very finegrained, laminated black carbonaceous sediments with fine grained tuffs and sediments, overlain by coarser felsic tuffs and sediments. These are intruded by a thick porphyritic basalt stock or sill, and by later latite dykes (Byington and Russell, 2001). The basalt was dated at 17.7 \pm 0.6 Ma (Wleklinski, 1969).

There are three arcuate-shaped deposits on the north side of a circular feature interpreted to be the rim of a caldera: Cerro Otero, Santa Rosa which is hosted by tuffs, and Alto de la Mina in fractured andesite (White, 1994). Alteration is central quartz-adularia-pyrite surrounded by zones of argillic (kaolinite-montmorillonite), carbonate and chlorite alteration. Gold mineralization is hosted by "jigsaw" breccias with a silicified milled rock matrix with low pyrite $(<1 \%)$ at Santa Rosa, and by a stockwork of quartz-calcite-pyrite-rich $(10 \%)$ veinlets at Alto de la Mina.

Byington and Russell (2001) describe a somewhat different four-stage history of tectonics and mineralization controlled by the NW-trending, dextral strike-slip Santa Rosa Fault and intersections with NE-trending fractures: 1) the first stage formed the fault which focused the intrusion of the basalt stock and latite dykes, and created funnel-shaped breccia pipes in dextral fault jogs described as diatremes of phreatomagmatic origin; 2) the second stage was strike slip fault movement and deposition of quartz and sulphides; 3 ) this was followed by deposition of $\mathrm{Au}-\mathrm{Ag}$ and pathfinder elements; 4) the final stage was barren and offset the upper part of the Alto de la Mina orebody with reverse movement. Most ore occurs in the breccia pipes (Figure 23) or is associated with the Santa Rosa fault in the basalt porphyry, but can occur up to $300 \mathrm{~m}$ from the fault in NE fractures. Alteration in the ore zones is silicification, pyrite and quartz veining with sericite, adularia and toumaline. There is a propylitic halo with chlorite and 


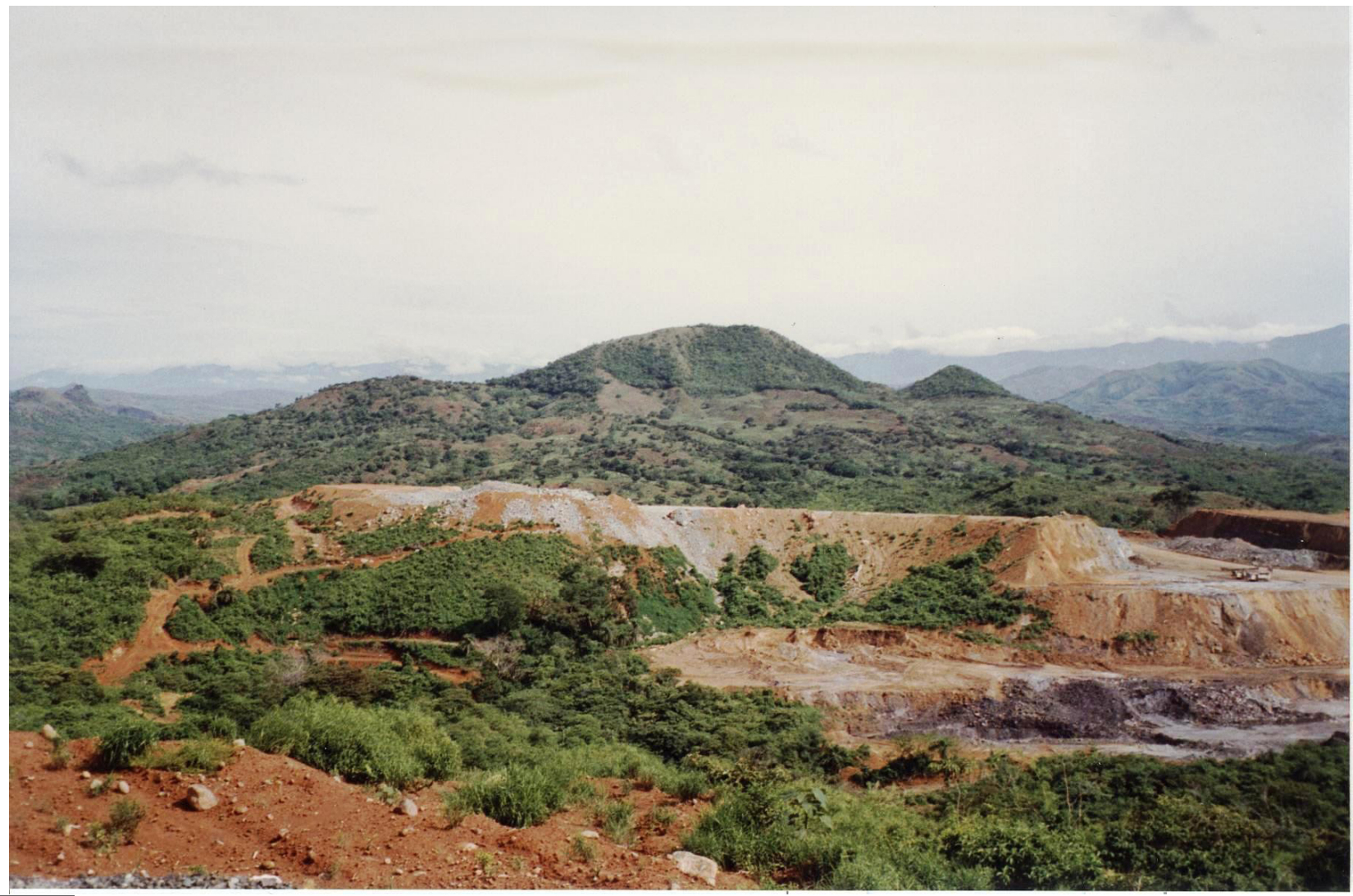

Figure 22 General view of the Santa Rosa mine looking north in 1997 (photo S. Redwood).

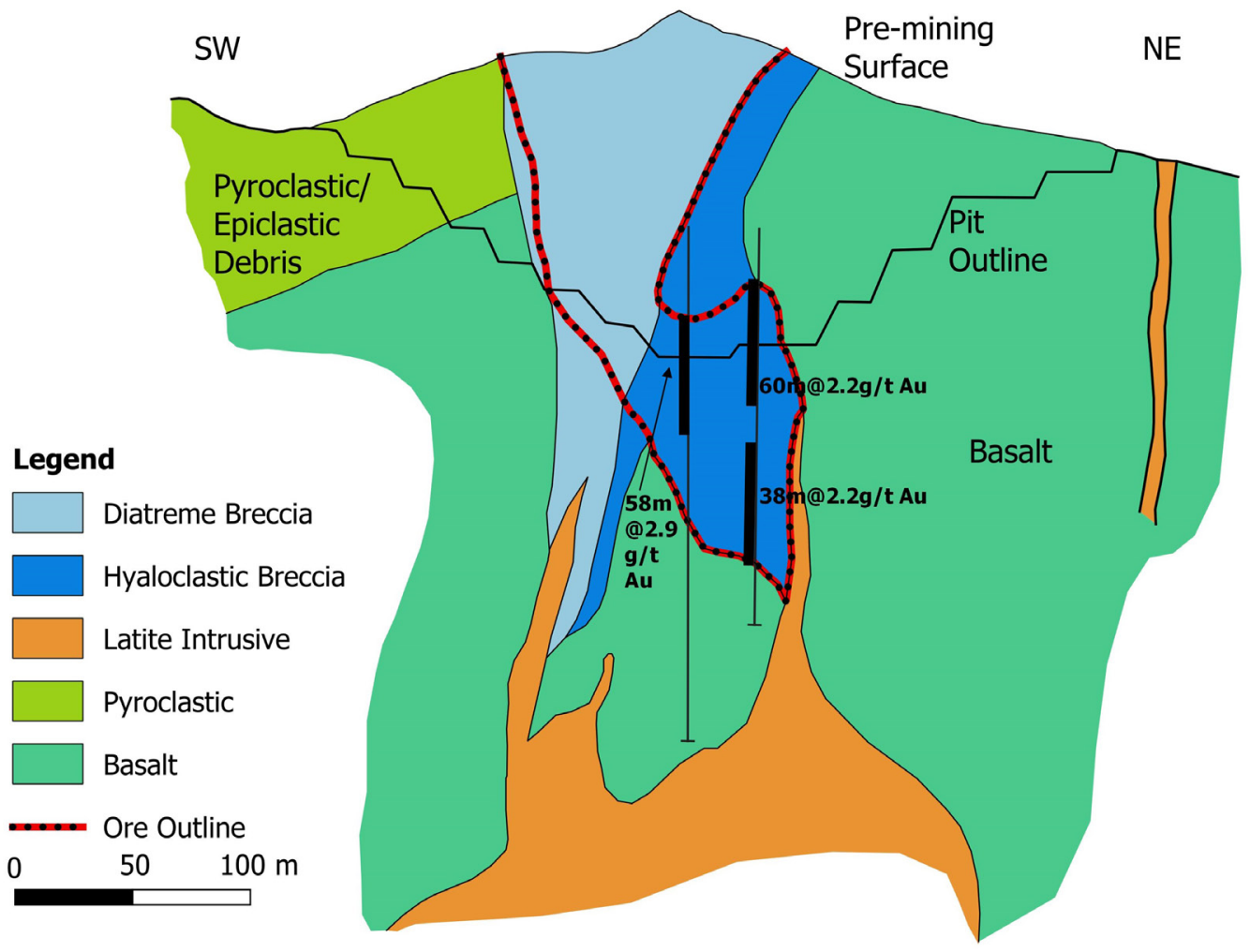

Figure 23 Schematic cross section through the Alto de la Mina orebody (modified after Byington and Russell, 2001). 
calcite veinlets, and an intermediate zone of calcite replacement by chalcedony, opal, quartz, adularia, calcite, pyrite and marcasite. Gold mostly occurs as electrum of 20-200 $\mu \mathrm{m}$ size on fractures and at pyrite grain boundaries, and is associated with minor marcasite and trace amounts of pyrrhotite, chalcopyrite, galena, arsenopyrite and sphalerite. Silver occurs in electrum, acanthite and the selenide aguilarite. Nelson (2001) described the geology as the margin of a maar eruption crater with basaltic and dacitic domes, plugs and dykes which created "hydrovolcanic" or hydrothermal vent breccias.

The common features of these descriptions are a pyroclastic sequence with laminated, carbonaceous sediments intruded by a basalt sill or stock and by felsic dykes, with crackle breccias and milled matrix breccias likely of phreatic or phreatomagmatic origin, with a structural control to the orebodies of either a caldera margin or a strike slip fault. Gold mineralization is associated with silicification, adularia and pyrite in breccia cement or crackle veinlets. Mineralization is low sulphidation epithermal type associated with breccias and structures.

\subsection{CERRO LAS MINAS LOW SULPHIDATION EPITHERMAL Au PROSPECT}

The Cerro Las Minas epithermal Au prospect lies 3 $\mathrm{km}$ north of Cañazas. Old mine workings date from the early 1900s. It was explored by UNDP (1966), Georecursos (1991), Minnova Inc. (1991-1992) and Arlo Resources (1995-1996). Vuggy quartz veins with up to $7.88 \mathrm{~g} / \mathrm{t} \mathrm{Au}$ are hosted by a diorite intrusion and a lapilli tuff. Old mine adits are on a vein trending $160^{\circ}$. Rock sampling defined a gold anomaly $>0.1 \mathrm{~g} / \mathrm{t}$ on the hill associated with argillic alteration and quartz veining.

9.2.8. CERRO CABALLO LOW SULPHIDATION EPITHERMAL Au PROSPECT

The Cerro Caballo epithermal gold prospect was explored by Freeport Exploration, Greenstone Resources and BHP Minerals in the 1980s-1990s. Eleven drill holes by Freeport in 1990 gave best intercepts of $41 \mathrm{~m}$ at $1.13 \mathrm{~g} / \mathrm{t} \mathrm{Au}, 56 \mathrm{~m}$ at $1.03 \mathrm{~g} / \mathrm{t}$ $\mathrm{Au}$ and $24 \mathrm{~m}$ at $1.13 \mathrm{~g} / \mathrm{t} \mathrm{Au}$, with the highest grade of $3 \mathrm{~m}$ at $9.8 \mathrm{~g} / \mathrm{t} \mathrm{Au}$. It estimated a mineral resource of $2 \mathrm{Mt}$ at $1 \mathrm{~g} / \mathrm{t} \mathrm{Au}$. Gold mineralization is hosted by a silicified and argillic altered lithic lapilli tuff similar to the host rocks at the Santa Rosa deposit. Other alteration zones with anomalous gold $(>0.1 \mathrm{~g} / \mathrm{t})$ on surface occur nearby at Cerro Brujo and Cerro Loro which are aligned on a $3.0 \mathrm{~km}$ long NW-trend. Mineralization is of low sulphidation epithermal style.

\subsubsection{RIO LIRI HIGH SULPHIDATION EPITHERMAL Au DEPOSIT}

The Rio Liri high sulphidation gold deposit is located in the northwestern part of the Soná peninsula $65 \mathrm{~km}$ west of Santiago and west of the Veraguas Gold Belt. The gold potential was first recognized by CEMSA in 1988. The Swedish Project reported Au above $200 \mathrm{ppb}$ in five samples in 1990 (SGI, 1991a). It was explored by Minnova Inc. in 1991-1994 which identified the Cerro Pelado target, and by Arlo Resources Ltd. in 1994-1995. It drilled 13 holes for 1,631 m in 1995 , with best results of $41 \mathrm{~m}$ at $1.53 \mathrm{~g} / \mathrm{t} \mathrm{Au}$, $14 \mathrm{~m}$ at $2.01 \mathrm{~g} / \mathrm{t} \mathrm{Au}, 26 \mathrm{~m}$ at $1.13 \mathrm{~g} / \mathrm{t} \mathrm{Au}$ and 34 $\mathrm{m}$ at $0.77 \mathrm{~g} / \mathrm{t}$ Au. Folk (2004b) later estimated an inferred mineral resource of $1.66 \mathrm{Mt}$ at $1.35 \mathrm{~g} / \mathrm{t}$ Au in oxides containing $2.25 \mathrm{t}$ of gold.

Mineralization occurs on Cerro Pelado, a distinctive, steep-sided, $\mathrm{N} 20^{\circ} \mathrm{E}$-trending, faultbounded hill that forms a horst (Figure 24). The host rocks are volcanic rocks of the Miocene Cañazas Formation. It is formed of a lithic lapilli tuff with minor bedded ash tuff which are underlain by a coarse porphyritic feldspar-quartz-hornblende-magnetite dacite dome or stock. Alteration and mineralization are silicification and vuggy quartz in pervasive zones and veinlets with specular hematite; quartz-kaolinite (argillic); dickite in matrix and veinlets (advanced argillic); chalcedony veinlets; pyrite, chalcocite, specular hematite; hematite oxidation; hydrothermal breccias with silicified clasts and silica matrix; and propylitic 


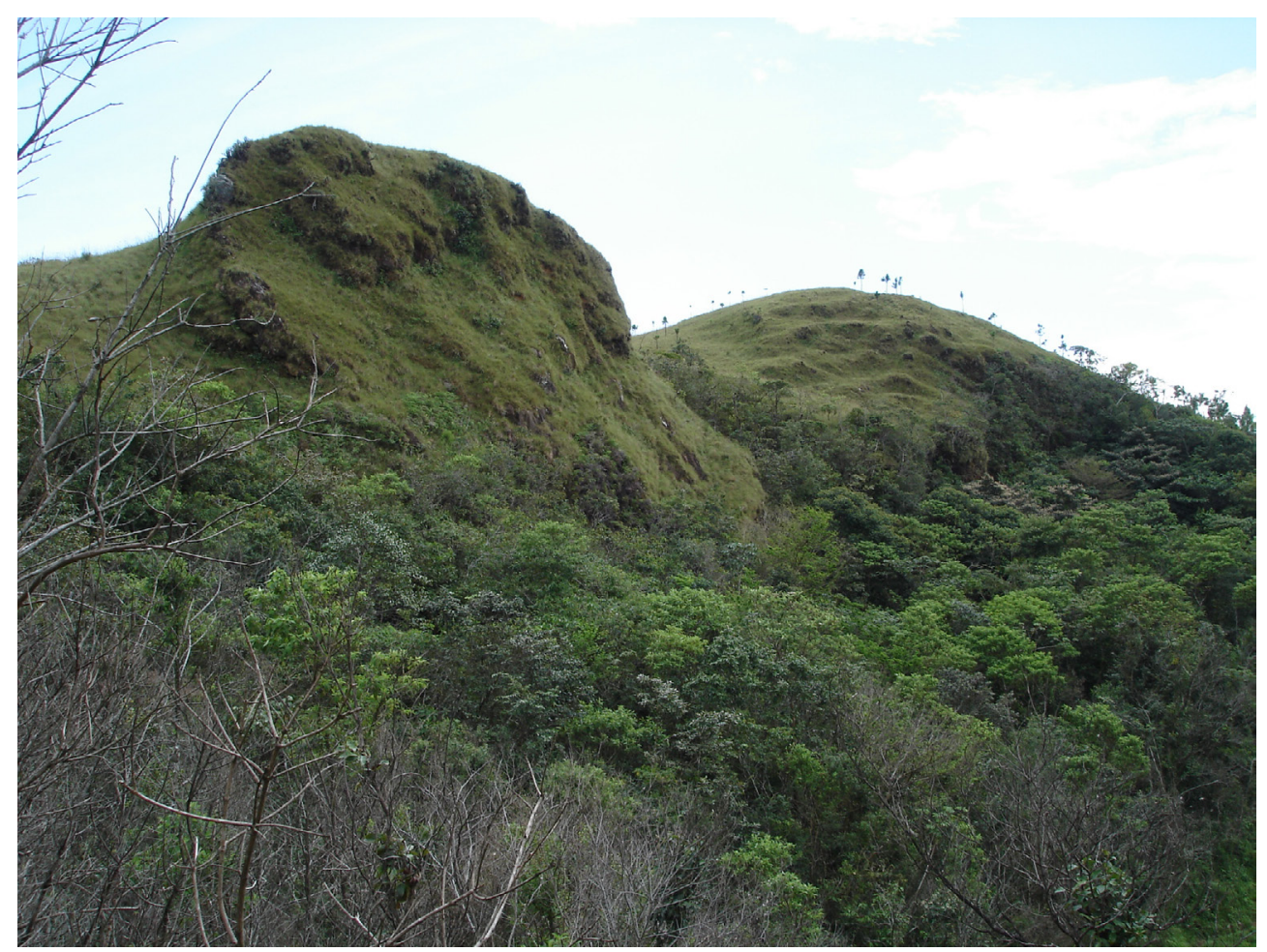

Figure 24 Silicified tuffs with gold mineralization form the fault-bounded Cerro Pelado at the Rio Liri prospect, viewed in 2005 (Photo S. Redwood).

alteration with disseminated pyrite and minor quartz veinlets in dacite. A soil gold anomaly of $250 \mathrm{~m}$ by $350 \mathrm{~m}$ with coincident $\mathrm{As}, \mathrm{Sb}$ and $\mathrm{Hg}$ anomalies. This is coincident with a high resistivity, low chargeability zone due to silicification and oxidation.

\subsection{WESTERN GENTRAL GORDILLERA PORPHYRY Cu BELT}

\subsubsection{CERRO COLORADO PORPHYRY CU DEPOSIT}

The Cerro Colorado porphyry copper deposit is located in the Central Cordillera of western Panama at an altitude of 900 to 1,460 m (Figure 25). It has been described by Issigonis (1982), Hargreaves (1974), Kents (1975), Clark et al. (1977), Kesler et al. (1977), Spatz (1979), Clark (1979), Linn et al. (1981a, 1981b) and Sides (1984).

The deposit was discovered by a private geologist in 1957 (Linn et al., 1981a) and was explored by several companies from 1969-2005. The most recent historical mineral resource estimate, made by Kvaerner Metals (1998) for PanaCobre, contains 1,754.7 Mt at $0.637 \% \mathrm{Cu}(11.2 \mathrm{Mt}$ or $25 \mathrm{Blb}$ contained copper) at $0.4 \% \mathrm{Cu}$ cut-off (measured + indicated + inferred resource), including 149 $\mathrm{Mt}$ at $0.69 \% \mathrm{Cu}$ in the supergene zone. These are contained within a global resource $(0 \% \mathrm{Cu}$ cut-off $)$ of 3,539.2 Mt at $0.417 \% \mathrm{Cu}(14.8 \mathrm{Mt}$ or $33 \mathrm{Blb}$ contained $\mathrm{Cu}$ ). The resource has credits for Mo, $\mathrm{Ag}$ and $\mathrm{Au}$ which were given in an earlier resource estimate as $0.006 \%$ Mo (212000 t Mo), $4.1 \mathrm{~g} / \mathrm{t}$ $\mathrm{Ag}(14,510 \mathrm{t} \mathrm{Ag})$ and $0.07 \mathrm{~g} / \mathrm{t} \mathrm{Au}(249 \mathrm{t} \mathrm{Au})(0 \%$ Cu cutoff) (Linn et al., 1981b). A Kvaerner Metals (1997) prefeasibility study for PanaCobre gave a mineral resource contained within an ultimate pit of $1,802 \mathrm{Mt}$ at $0.66 \% \mathrm{Cu}$, with a high grade pit of $350 \mathrm{Mt}$ at $0.74 \% \mathrm{Cu}$. The supergene copper zone has $61.104 \mathrm{Mt}$ of proven and probable ore reserves with grades of $0.459 \% \mathrm{Cu}$ soluble and $0.730 \% \mathrm{Cu}$ total.

Cerro Colorado is a porphyry copper deposit of late Miocene to Pliocene age, with mineralized porphyries dated at $5.90 \pm 0.10 \mathrm{Ma}$ and post-mineral rhyodacite dykes at $4.21 \pm 0.08 \mathrm{Ma}$ (Clark et al., 1977). It is a single deposit with dimensions of the mineralization of $1,800 \mathrm{~m}$ E-W by $1,300 \mathrm{~m}$ 
N-S, with a known vertical extent of over 1,000 m. The majority of the resource is primary but there is a leached cap up to $90 \mathrm{~m}$ thick, underlain by a secondary copper enrichment blanket 40 to $150 \mathrm{~m}$ thick.

It is hosted by a porphyry stock which cuts andesitic to dacitic volcanic rocks of Oligocene to Miocene age (Figure 26). The porphyries are an early mineral quartz diorite porphyry, intermineral granodiorite porphyry, late mineral diorite and granodiorite porphyries, and post-mineral rhyolite and rhyodacite dykes. There are inter-mineral phreatic breccias.

The principal hydrothermal alteration is biotite alteration with early biotite and magnetite veinlets and an A and B quartz veinlet stockwork with pyrite, chalcopyrite, bornite, molybdenite and/or magnetite. Molybdenum forms a zone of 0.020.04\% Mo in the core of the deposit at depth (Linn et al., 1981b). There is retrograde chlorite alteration. There is a sericite alteration overprint which can occur up to the greatest depths drilled of $+800 \mathrm{~m}$. This is accompanied by quartz-pyrite veinlets, thicker pyrite veins, and late molybdenite veinlets. There are minor late stage veinlets of barite with tennantite-tetrahedrite and sphalerite.

The leached cap is goethitic. The supergene enrichment zone consists of chalcocite and covellite replacing primary sulfides. Both the leached cap and enrichment zone are accompanied by supergene argillic alteration to white clays. The enrichment zone overlies the primary sulphide zone with leached gypsum, with a top of gypsum at depth followed by the anhydrite zone at greater depth.

\subsubsection{CERRO CHORCHA PORPHYRY Cu-Au DEPOSIT}

The Cerro Chorcha porphyry $\mathrm{Cu}-\mathrm{Au}$ deposit is located in rugged mountainous terrain in the Central Cordillera of western Panama, $37 \mathrm{~km}$ west of Cerro Colorado, at 600 to 2,213 m altitude. The geology was described by Folk (2005) and Druecker and Sandefur (2008).
Copper mineralization was discovered at Cerro Chorcha by Asarco Minerals Ltd. by a regional stream sediment sampling program which started in 1969. By 1976 it had outlined porphyry copper mineralization $>0.2 \% \mathrm{Cu}$ by trenching over an area of $600 \mathrm{~m}$ by $300 \mathrm{~m}$ in the Guariviara Zone. The project was drilled by Arlo Resources Ltd. (managed by MK Gold Company) and GeoRecursos International S. A. in 1994-1995; Cyprus Minerals in 1997-1998; and Bellhaven Copper \& Gold Inc. and Dominion Exploration in 20072008. A total of $10,546 \mathrm{~m}$ of diamond drilling was carried out in 47 holes. The deposit has indicated and inferred mineral resources in the Guariviara Zone of $202 \mathrm{Mt}$ grading $0.49 \% \mathrm{Cu}$ and $0.07 \mathrm{~g} / \mathrm{t}$ $\mathrm{Au}$ (cut-off $0.2 \% \mathrm{Cu}$ ), including a higher grade hypogene central zone of $37.4 \mathrm{Mt}$ at $0.93 \% \mathrm{Cu}$ and $0.16 \mathrm{~g} / \mathrm{t} \mathrm{Au}$ (cut-off $0.65 \% \mathrm{Cu}$ ) (Druecker and Sandefur, 2008). There are high grade hypogene zones with drill intersections such as $144 \mathrm{~m}$ at $1.82 \% \mathrm{Cu}$ and $0.37 \mathrm{~g} / \mathrm{t} \mathrm{Au}$.

Mineralization is hosted by a composite porphyry stock of diorite, quartz diorite, monzodiorite and dacite composition which cuts Miocene-age Cañazas Formation andesite lapilli tuffs and flows (Figure 27). The porphyries have not been dated but are assumed to be a similar age to Cerro Colorado of about 4-6 Ma. The porphyries lie just north of a large (9 km by $12 \mathrm{~km}$ ) granodiorite/tonalite intrusion of the Tabasara Group of Miocene-Pliocene age. The porphyries are cross-cut by post-mineral dykes of mafic to intermediate composition. Most of the primary sulphide (chalcopyrite and bornite) mineralization occurs in structurally controlled quartz-magnetite stockworks and veins in the quartz diorite porphyry intrusions. The veinlet sequence is: 1) actinolite-chlorite-magnetite-sulphide; 2) quartz-magnetite-chalcopyrite-bornite (quartz-magnetite stockwork mineralization); 3) late quartz-chalcopyrite-bornite-pyrite-zoisite (porphyry style quartz stockwork mineralization); and 4) very late zoisite-carbonate-(pyrite) veinlets. The two main events are structurally controlled quartz-magnetite stockwork veining over a length 


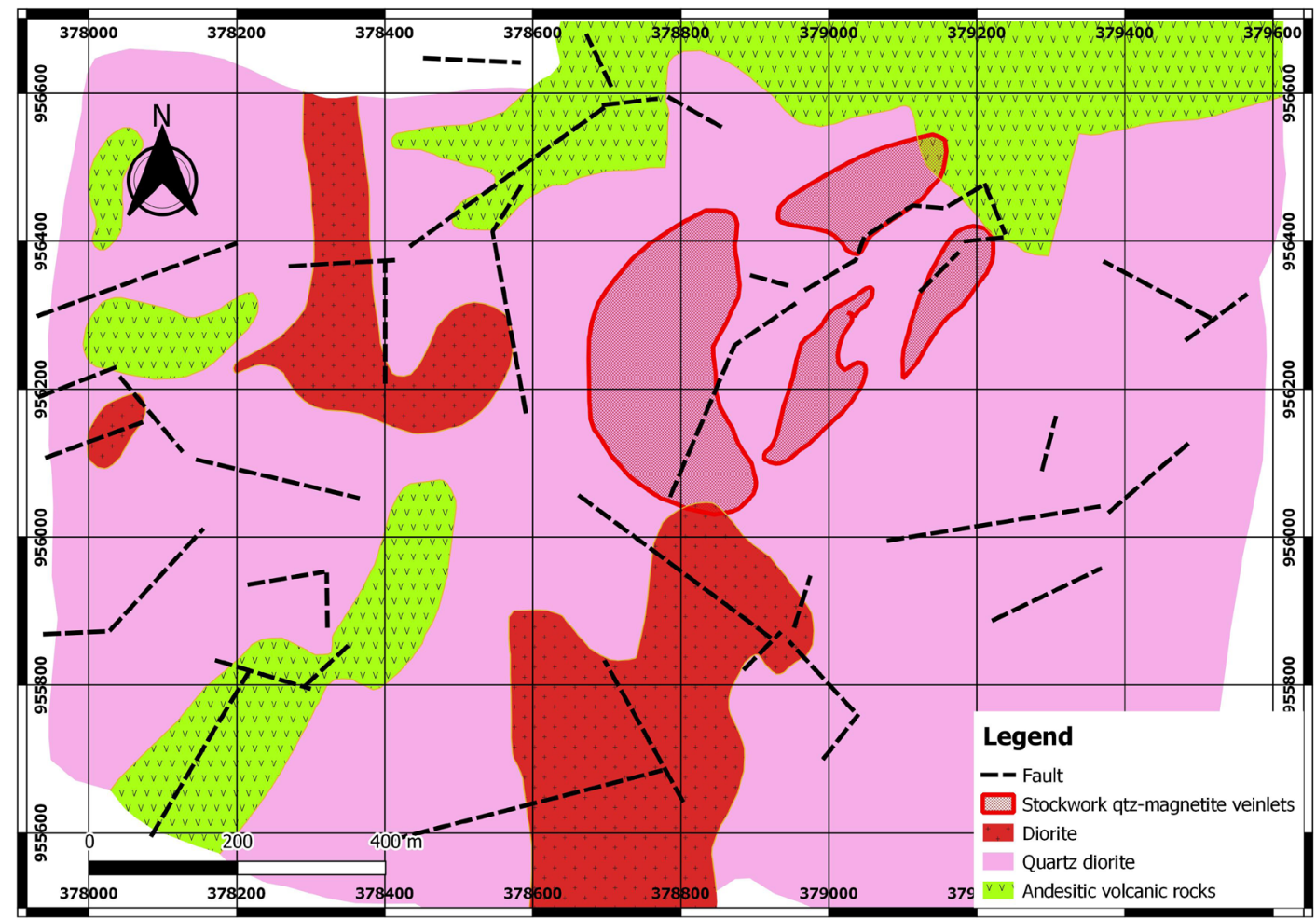

Figure 27 The geology of the Cerro Chorcha porphyry deposit (modified after Druecker and Sandefur, 2008).

of $1,100 \mathrm{~m}$ and widths of 25 to $150 \mathrm{~m}$, and porphyry-style quartz stockwork veining over an area of at least $1,300 \mathrm{~m}$ by $600 \mathrm{~m}$. Alteration is dominated by sericite-illite alteration with relics of potassic alteration, surrounded by propylitic alteration.

Oxidation is partial and can be up to $135 \mathrm{~m}$ deep with black copper oxide, chrysocolla, covellite, malachite, azurite and minor native copper encountered, and only minor supergene sulphides (Folk, 2005; Druecker and Sandefur, 2008).

\section{Quaternary deposits formed by wathering}

\subsection{GHIRIQUI-VERAGUAS LATERITIC BAUXITE AND IRON ORE DEPOSITS}

Bauxite deposits occur at Las Palmas in Veraguas and at Tolé and David in Chiriqui in western Panama in a belt about $145 \mathrm{~km}$ long, and include a lateritic iron ore prospect at La Mesa. The bauxite deposits have been described by Wilmot (1960),
Patterson (1967), Quirós (1962; 1975), del Giudice and Recchi (1969), Ferenčić (1971) and Patterson et al. (1986). None of the deposits have been exploited. The Veraguas deposits are small and there are no resource estimates.

\subsubsection{DAVID AND TOLÉ BAUXITE DEPOSITS}

The Chiriqui deposits were investigated by the Aluminum Company of America (Alcoa) and Kaiser Aluminum Company of the US from 1956 to the 1960s, which estimated resources of $70 \mathrm{Mst}$ (64 Mt) of bauxite grading $40 \% \mathrm{Al}_{2} \mathrm{O}_{3}$ and $6 \%$ $\mathrm{SiO}_{2}$ (Quirós, 1975).

Blanket-type deposits of bauxite occur on the surface in Chiriqui Province for a distance of about $85 \mathrm{~km}$ and a width of $25 \mathrm{~km}$ between David and Tolé at elevations between sea level and 200 m (Quirós, 1975). The deposits vary in thickness from a few centimeters up to $10 \mathrm{~m}$. The main deposits at David and Tolé have different chemical compositions. The David deposit has $46 \% \mathrm{Al}_{2} \mathrm{O}_{3}$, $17 \% \mathrm{Fe}_{2} \mathrm{O}_{3}$ and $10 \% \mathrm{SiO}_{2}$, of which $6 \%$ is reactive, while the Tolé deposit has $46 \% \mathrm{Al}_{2} \mathrm{O}_{3}, 28 \%$ $\mathrm{Fe}_{2} \mathrm{O}_{3}$ and $4 \% \mathrm{SiO}_{2}$, of which $3 \%$ is reactive. The 
bauxite is divided into two classes, $\mathrm{A}$ and $\mathrm{B}$, for the estimation of reserves: class $\mathrm{A}$ has a minimum of $30 \%$ alumina recoverable by the Bayer method, and class B has 25-30\%. Reserves of class A bauxite were estimated at $37 \mathrm{Mt}$ grading $36.5 \% \mathrm{Al}$ with an average thickness of $2.2 \mathrm{~m}$, and reserves of class B bauxite were $32 \mathrm{Mt}$ grading 29.3\% $\mathrm{Al}$ with an average thickness of $1.6 \mathrm{~m}$. The area of the deposits is $35 \mathrm{~km}^{2}$ but it is made up of numerous small deposits (Quirós, 1975).

The bauxite deposits are tropical lateritic bauxite deposits formed by tropical weathering of intermediate volcanic rocks in Pleistocene to Recent times (Patterson, 1967). Quirós (1975) described two types of source: the deposits at lower elevation formed from gravels of intermediate composition volcanic rocks, while those at higher elevation formed from weathering of in situ volcanic rocks of more basic composition, resulting in higher iron and titanium content.

\subsubsection{LA MESA LATERITIC IRON ORE PROSPECT}

A lateritic iron ore prospect occurs at La Mesa, about $20 \mathrm{~km}$ west of Santiago, on the Meseta de Veraguas (or El Alto de la Mesa) plateau which is about $13 \mathrm{~km}$ long by $3 \mathrm{~km}$ wide with an ENEtrend. It is described as a bed of hematite underlain by basalt by Riddell (1927), and as goethite by del Giudice (1965). It appears to be an iron-rich lateritic deposit with a similar origin to the bauxite deposits but derived from the weathering of ironrich basalt.

\subsection{HEAVY MINERAL SANDS (Fe-Ti)}

Five shallow marine placer deposits of heavy mineral sands occur over a distance of $60 \mathrm{~km}$ between Punta Chamé and Boca del Río Hato on the Pacific coast in Panama West and Coclé provinces. They have estimated "proven reserves" of 3.0 Mt at an unspecified grade (del Giudice and Recchi, 1969; Quirós, 1975). The shallow marine deposits off Gorgona Beach were exploited by dredging in 1971-1972 by Hierro Panama S. A., a joint venture between Sumitomo Corporation of Japan and Minera Chame S. A. of Panama. The black sands were stockpiled and concentrated by electromagnets at a plant on Bona Island, and loaded onto bulk carriers for export to Japan. A total of 200,000 metric tons of concentrates of magnetite and ilmenite grading $64 \% \mathrm{Fe}$ and $6 \% \mathrm{TiO}_{2}$ were produced and 75,000 metric tons were exported in three shipments.

An accident occurred on the fourth shipment when the ship was blown against the loading pier and badly damaged it, and the operation was abandoned.

The deposits are beach and marine placer deposits which have concentrated heavy minerals derived from the weathering of volcanic rocks. Occurrences of black sands are known in other parts of the country but no others have been evaluated or exploited.

\subsection{PLACER GOLD}

\subsubsection{INTRODUCTION}

Placer gold deposits of alluvial type are common in Panama and include a paleo-alluvial (deep lead) deposit. They have been exploited since the pre-Columbian period and were particularly important producers during the early Spanish colonial period in the late $16^{\text {th }}$ to early $17^{\text {th }}$ centuries. However, none have been exploited on a large, industrial scale by bucket-wheel dredges comparable to the placer deposits of Colombia. Placer goldfields occur in four main areas: 1) the eastern part of Darien Province; 2) and the rivers of northern Veraguas and Coclé that flow into the Gulf of Mosquitos of the Caribbean Sea; 3) Chepo, and 4) southern Veraguas in western Azuero and Soná. In addition, small placer gold deposits are recorded at many of the other mineral deposits and prospects in Panama.

\subsubsection{NORTHERN DARIEN PLACER GOLDFIELD}

The rich placer gold mines of the northern Darien near Santa María la Antigua, at the mouth of the River Atrato (now in Chocó, Colombia), were first described by Vasco Nuñez de Balboa in 1513 (Blas Aritio, 2014). The region was exploited in the first 
years after the conquest (1514-1526) during which Castilla de Oro produced 13.5 t of gold obtained by raids, trade and mining (Castillero Calvo, 2008, 2019; Mena García, 2011).

\subsubsection{DARIEN PLACER GOLDFIELD}

The main placer deposits in the Darien goldfield are in the southeastern part on the Rivers Chuqunaque, Tuquesa, Marraganti, Tuira, Balsas (Tucuti) and Bagre (Marea) (Sheridan, 1926; Oller, 1933, 1975; UN, 1972b). The deposits were first worked by the Spaniards in about 1665. The Tuquesa, Chuqunaque, Balsa and Sabalo (or Tucuti) placers were evaluated by the Panama Corporation Ltd in 1928-1931 (Sheridan, 1926; Low, 1931; Hull, 1940) and by the Isthmian Corporation in 1941 (Stranahan, 1941). Gold exports from Darien in 1931-1941 averaged 5,200 ounces (162 kg) a year with a peak of 13,895 ounces $(432 \mathrm{~kg})$ in 1934 (Roberts and Irving, 1957). The River Pito placer gold deposits, on the Caribbean drainage, were evaluated by UNDP (UN, 1972b). Further west in the Majé Massif, alluvial gold occurs in the Rivers Pasiga and Tigre (UN, 1972b).

The placer gold deposits of the Darien are derived from the porphyry $\mathrm{Cu}-\mathrm{Au}$ systems of Rio Pito, Cana and Acandi (Colombia), and the Espiritu Santo de Cana and Rio Mogue epithermal gold deposits. Additional sources are other, presumably epithermal, quartz-gold vein deposits which were mined historically. These include the El Pablo vein at La Marea on the River Marea which was mined in the early $17^{\text {th }}$ century (Lach-Szyrma, 1909; Low, 1931); the Mother Lode veins which are more than $3 \mathrm{~km}$ long and 1.2-5.5 m wide with Spanish mine workings on the River Marraganti, a major tributary of the River Tuquesa (Sheridan, 1926); and veins at the San Francisco mine on the River Tuquesa, worked in the early $20^{\text {th }}$ century (Oller, 1933, 1975).

\subsubsection{RIVER BALSAS PLACER Au DEPOSIT}

Pitting and churn drilling by the Panama Corporation Ltd on the River Balsas and its tributary the River Sabalo, near Tucutí, in 1928-1931, defined reserves of 4.1 million cubic yards with a value of 18.36 cents per cubic yard $\left(163 \mathrm{mg} / \mathrm{yd}^{3}\right.$ at the then gold price of $\$ 35$ per ounce) containing about 670 t of gold (Low, 1931; Hull, 1940).

\subsubsection{RIVER TUQUESA PLACER A U DEPOSIT}

The River Tuquesa placer deposits are probably the largest in Panama and the broad reaches of the lower part of the river were described as suitable for mining by dragline and bucket-wheel dredges. The placer deposits were evaluated by the Panama Corporation Ltd in 1928-1931 by pitting and churn drilling and were estimated to contain resources of 184 million cubic yards with a value of $\$ 0.72-\$ 0.98$ per cubic yard $\left(640-871 \mathrm{mg} / \mathrm{yd}^{3}\right)$ containing 160 t gold (Sheridan, 1926). In 1941 the Isthmian Corporation estimated resources of 155 million cubic yards with a value of $\$ 1.043$ per cubic yard $\left(927 \mathrm{mg} / \mathrm{yd}^{3}\right)$ containing $143 \mathrm{t} \mathrm{Au}$ (Stranahan, 1941).

\subsubsection{CHEPO PLACER GOLDFIELD}

Placer gold occurs on the Rivers Terable, Bayano and Mamoni in the Chepo district, east of Panama City. Alluvial gold mining on the River Bayano near El Llano was described by Oller (1933, 1975). In 1941, the Isthmian Corporation estimated reserves of 150 million cubic yards at $35 \mathrm{c}$ per cubic yard $(311 \mathrm{mg})$, containing $47 \mathrm{t}$ gold, between the River Terable and the town of Pintuko (Stranahan, 1941). SGI (1991a) studied a placer gold deposit in terraces over $20 \mathrm{~km}$ in length on the upper River Mamoni which was being mined at the time by a large number of artisanal miners.

\subsubsection{COCLÉ PLACER GOLDFIELD}

The Coclé and Veraguas placer goldfields are a single district but are described separately because of their different histories. The auriferous rivers of the Coclé district are the Chiquero, Petaquilla, Caimito, San Juan, Toabré and Coclé del Norte in the Donoso District of Colón Province (Griggs, 2005). The source of the alluvial gold is the porphyry and epithermal deposits of Cobre Panama, 
Molejon and Palmilla. Spanish documents record that alluvial gold deposits in the Coclé region were mined by indigenous tribes in 1522-1526. The Spaniards conquered the region in 1603 and founded the mining settlement of Nueva Lisboa near the mouth of the River Coclé del Norte. There were also historical Spanish mines on quartz-gold veins, presumed to be epithermal, at San Antonio and Santa Lucia (with lead) on the River Cocle del Norte (Griggs, 2005). Another Spanish gold rush was centered on the mining town of La Palma which was founded in 1619 on the River Palmilla, a tributary of the River Chiquero (Castillero Calvo, 2008).

\subsubsection{VERAGUAS PLACER GOLDFIELD}

Placer gold occurs on the Rivers Santiago, Concepción, Veraguas and Belén in the foothills and the Caribbean lowlands of the Santa Fé district in northern Veraguas in the continuation of the Coclé district. The Veraguas district was an important Spanish gold producer in the late $16^{\text {th }}$ century. The most important mine was Cocuyo on the River Santiago which was mined from 1559-1589 and produced about 9 metric tons of gold from alluvial and quartz vein deposits. The town of Concepción was established at the river mouth and the mining settlement of Santiago de Turlurú between the Santiago and Barrera rivers (Castillero Calvo, 1967a, 2008; Wleklinski, 1969). Mining was re-started at Concepción in 16291640, and has continued intermittently since the $18^{\text {th }}$ century. The Veraguas gold district was evaluated by United Nations in 1965-1969 as part of the Azuero Mining Project (Wleklinski, 1969). The placer gold deposits are alluvial, terrace and buried paleo-channel deposits. The gold is derived from epithermal veins, the best known of which is Margaja.

\subsubsection{COCUYO-GUINEA DEEP-LEAD PLACER A D DEPOSIT}

Part of the historical production in the Veraguas gold belt was from an alluvial deposit in an old valley covered by a young basalt flow 8-10 m thick and about $40 \mathrm{~m}$ above the present valley on the ridge between the Rivers Santiago and Barrera. The deposit was mined in 1559-1589 from over 400 tunnels dug below the basalt. It was evaluated by the Panama Corporation Ltd in 1928-1931 (Low, 1931), and by the UN (1969) program in 1965-1969 (Wleklinski, 1969). The paleochannel dips gently at about one degree from a wide valley at Cocuyo (230 m altitude) to a narrow valley at Guinea (190 m altitude). The UN estimated an area of $850,000 \mathrm{~m}^{2}$ with containing $3.2 \mathrm{Mt}$ of gravel at $0.3 \mathrm{~g} / \mathrm{t}$ Au containing 1 metric ton of gold, or, if the head grade is higher at $1.5 \mathrm{~g} / \mathrm{t}$, with a resource of $5 \mathrm{t}$ gold (Wleklinski, 1969).

\subsubsection{SOUTHERN VERAGAUS PLACER GOLDFIELD}

Small placer gold deposits occur in several rivers in the western Azuero and Soná peninsulas of southern Veraguas and were exploited by the Spanish in minor gold rushes in the $16^{\text {th }}-17^{\text {th }}$ century as the region was settled. These were on the River Tebario and River Quebro in the hills of Guanete (Azuero Massif), around the mining town of San Juan de Mariato (now Llano de Catival or Mariato), and the River Tabarabá (now called the River San Pablo) near Montijo where the lost town of Nuestra Señora de la Regla was founded (Castillero Calvo, 1967b; 2008).

The alluvial gold of western Azuero is derived from high sulphidation epithermal $\mathrm{Au}-\mathrm{Cu}$ prospects such as Quebrada Barro, Cerro Viejo and Los Ñopos, while that of the Tabarabá may have its origin from the Soná porphyry gold prospect and the low sulphidation epithermal Au deposits of the Veraguas Gold Belt.

\subsection{PLACER PLATINUM}

The only known but unconfirmed occurrences of platinum in Panama are in placer deposits in the Chuqunaque and Tuquesa rivers in Darien Province. They were described by Low (1931) while evaluating the gold placers of the Chuqunaque River for the Panama Corporation Ltd. of England in 1928-1930. He reported alluvial gold on the 
river banks "containing an appreciable amount of platinum", and, $40 \mathrm{~km}$ upstream, on the River Tuquesa, he examined a "gold-with-platinum prospect". These unconfirmed alluvial platinum occurrences may be a continuation of the Chocó placer platinum belt of Colombia. These deposits are believed to be derived from small, zoned ultramafic-mafic Alaskan-style plutons (Tistl, 1994; Tistl et al., 1994), which are common in deeply eroded arcs (Foley et al., 1997).

\section{Discussion}

\subsection{EXHALITE Si-Mn-(Fe) AND VMS Au-Cu-Zn MINERALIZATION IN THE EARLY ARG}

Widespread deposits of Si-Mn-(Fe) oxides associated with jasper and chert hosted by sedimentary rocks that occur in the Nombre de Dios and Montijo belts are of probable exhalative origin and precipitated either on the sea-floor or formed sub-sea-floor replacements. They are spatially associated with occurrences of $\mathrm{Cu}$ at Boqueron, Au-rich stockwork feeder zones of $\mathrm{Cu}-\mathrm{Zn}$ of probable VMS style at Viento Frio, and with pyrite-cemented brecciated basalt at Maria Chiquita. These poorly known deposits occur in submarine volcanic and sedimentary rocks of the Campanian-Eocene arc. The Si-Mn-Fe oxide mineralization resembles the siliceous exhalite or tuffite sedimentary horizon that form a veneer over the top of massive sulphide mounds and extends as a stratigraphic marker laterally away from the deposit (e.g. Lydon, 1984; Franklin et al., 2005). These exhalites are usually pyritic or hematitic, but in some deposits they have Mn oxides, as in the Iberian pyrite belt where they are widespread and formed in a shallow marine environment (Leistel et al., 1998). Similar manganese deposits occur on the Nicoya Peninsula in Costa Rica (Kuÿpers and Denyer, 1979). The age of the Panamanian deposits is poorly constrained. Their distribution indicates submarine segments of the arc which are thus not favorable for the development of subaerial porphyry-epithermal Cu-Au systems.

\subsection{LATE GAMPANIAN SUBDUCTION INITIATION, ARC EMERGENGE AND Au-Cu MINERALIZATION}

The Southern Azuero arc and Au-Cu belt represents the early development of an arc on the trailing edge of an oceanic plateau, the Caribbean Large Igneous Province. The 70.7 Ma age of mineralization at the Cerro Quema epithermal-porphyry $\mathrm{Au}-\mathrm{Cu}$ system indicates the rapid evolution of the arc from subduction-initiation at $\sim 75-73$ Ma through early, proto-arc primitive intraoceanic submarine mafic volcanism to more evolved, subaerial felsic island arc magmatism at $\sim 71 \mathrm{Ma}$ with a fully developed belt of hydrothermal alteration and mineralization (Buchs et al., 2011b; Corral et al., 2012; 2016; Perelló et al., 2020). Hydrothermal telescoping at Cerro Quema is indicative of regional arc emergence and uplift resulting in subaerial environment (Perelló et al., 2020).

\subsection{PRESERVATION, UNROOFING AND OXIDATION OF AN OLD HIGH SULPHIDATION EPITHERMAL DEPOSIT}

The preservation of lithocaps and high sulphidation epithermal systems in an old belt at Cerro Quema is unusual, as most such deposits globally are middle Miocene or younger in age. Older deposits are rarely preserved due to their susceptibility to erosion and special conditions are required for the preservation of older deposits such as burial. The Rio Quema Formation and the mineralized dome were buried by fore arc sediments of the late Eocene to Miocene Tonosi Formation which are believed to have preserved the deposit. The deposits occur in topographically high ground up to $920 \mathrm{~m}$ altitude with high relief of almost $800 \mathrm{~m}$, despite the age of the rocks. The strike of the topographic high follows the orientation of a major set of faults (Buchs et al., 2011b). These observations indicate recent tectonism and uplift in the fore-arc linked to subduction processes (Buchs et al. 2011b) or to left lateral strike slip movement along the Azuero Fault and others related to the movement on the Panama microplate / Nazca plate boundary and the collision of 
the Panama arc with the Northern Andes in the late Miocene (Mann and Kolarsky, 1995; Kolarsky et al., 1995a).

The horst uplift and removal of the sedimentary cover exposed the Cerro Quema deposit to erosion and formation of a $150 \mathrm{~m}$ thick oxide zone to form an economic gold oxide deposit (discussed below). The timing of oxidation is thus indicated by tectonic history to be relatively young in the history of the deposit at late Miocene to Recent.

\subsection{THE GONTRASTING DISTRIBUTION OF METALLOGENIC BELTS}

There is a contrasting distribution of the metallogenic belts between eastern and western Panama. In western Panama, the copper-gold belts show a progressive younging from south to north away from the subduction zone, from the late Campanian-early Eocene Au-Cu belt of southern Azuero-Soná, to the Eocene Au belt of northern Azuero-Soná, and the Miocene-Quaternary Au-Cu belt of the Central Cordillera (Figure 5). The exception to this trend is the Oligocene Petaquilla belt on the northern side of the Central Cordillera, which is discussed below. The northward migration may be due to progressive flattening of the subduction zone and/or subduction erosion of the fore-arc (Buchs et al., 2011b).

In contrast, in eastern Panama the $\mathrm{Cu}-\mathrm{Au}$ belts young in the opposite direction from north to south, with the late Campanian-early Eocene San Blas Cu-Au belt on the northern side, and the poorly known Oligocene to early Miocene $\mathrm{Au}-\mathrm{Cu}$ belt of Darien on the southern side. This is the result of collisional tectonics of the arc with South America starting in the middle Eocene, resulting in block rotation and offset of the western part of the Early Arc by $200 \mathrm{~km}$ left laterally, and the development of a fore-arc basin in eastern Panama which may have been due to steepening of the subducting Farallon Plate and ultimately slab break-off (Whattam et al., 2012; Barat et al., 2014). Following the break-up of the Farallon Plate in the late Oligocene, the location of the volcanic arc and $\mathrm{Au}-\mathrm{Cu}$ belt related to NE-dipping subduction of the Nazca Plate jumped to the south of the basin. Indeed, it was the study of metallogenic belts that identified the presence of the Middle Arc in this belt (e.g. Kesler et al., 1977; Redwood, 2010), all previous studies showing only Cretaceous ocean plateau basalt of the CLIP. Arc magmatism ceased in eastern Panama in the early to middle Miocene due to the change in the Nazca Plate convergence angle to strike-slip, and the poorly defined $\mathrm{Cu}-\mathrm{Au}$ belt records the cessation of subduction-related magmatism. In western Panama, oblique subduction continued throughout the Miocene and Quaternary to build up a thick subaerial volcanic arc in the Central Cordillera with related $\mathrm{Au}$ and $\mathrm{Cu}$ mineralization.

\subsection{THE ANOMALOUS LOGATION OF THE GOBRE PANAMA DEPOSIT}

The location of the Petaquilla batholith and Cobre Panama porphyry $\mathrm{Cu}$ deposits of lower Oligocene age on the northern side of the Miocene to Quaternary volcanic arc is anomalous with respect to the northward younging of arcs and $\mathrm{Au}-\mathrm{Cu}$ belts in western Panama (Baker et al., 2016 and Redwood et al., 2021). The lower Oligocene intrusive age was considered to be an inlier of the early part of the Neogene arc and $\mathrm{Cu}$-Au belt, although the back arc position remains unexplained. The biostratigraphic dating of the host volcanic rocks as late Eocene in age suggests as alternative explanation that it is part of the Early Arc and $\mathrm{Cu}-\mathrm{Au}$ belt (Redwood et al., 2021).

The age of the volcanic rocks at Cobre Panama overlaps with the ages of volcanic and plutonic rocks of the Eocene belt of the Northern Azuero-Soná arc and Au belt (Lissinna, 2005), about $80 \mathrm{~km}$ to the south, and in the San Blas-Chagres mountains of eastern Panama (Figure 5; Lissinna, 2005; Wegner et al., 2011; Montes et al., 2012a, 2015; Cardona et al., 2018). The Cobre Panama volcanic rocks are interpreted to be part of the late Campanian-Eocene arc and $\mathrm{Cu}-\mathrm{Au}$ belt, and together with the intrusive and mineralization ages of 32.2-27.5 Ma, extend the age of this belt into the early Oligocene. This interpretation 
would indicate that the Early Arc continues west to Petaquilla from San Blas and Chagres. This requires that the fault that caused the sinistral displacement of the arc must be west of Petaquilla, as shown by Montes et al. (2012a, 2012b), rather than, or in addition, to an inferred fault in the Panama Canal (Lissinna, 2005; Barat et al., 2014). An alternative explanation is that that the Petaquilla volcano-plutonic center represents the northward migration of the late Eocene arc post-displacement, and is a window or inlier below the wide Miocene arc of the Central Cordillera. The large displacement would suggest either a back-arc setting or arc broadening due to flattening of the angle of subduction.

\subsection{EPITHERMAL Au DEPOSITS IN THE GENTRAL CORDILLERA BELT}

The Central Cordillera of western Panama hosts epithermal gold deposits in the eastern and central part, and porphyry copper deposits in the western part. The epithermal deposits are low sulphidation epithermal veins (e.g. Capira, Remance) and breccias (e.g. Santa Rosa), often related to felsic domes and their pyroclastic aprons with fine grained, carbonaceous sediments interpreted to have been deposited in anoxic crater lakes or maars (Nelson, 2001). The veins have regional structural controls which are commonly N-S. An extensional setting is typical of low sulphidation veins (e.g. John, 2001; Sillitoe, 2002; Simmons et al., 2005), and suggests that regional extension of the arc, possibly as a result of highly oblique subduction, played an important role in metallogenesis. The scarcity of high sulphidation (Cerro Pelado and Rio Liri), and intermediate sulphidation epithermal deposits (Los Hatillos?) is notable and the reason is not understood.

\subsection{ASEISMIC RIDGE GOLLISION AND PORPHYRY Cu DEPOSITS IN THE WESTERN GENTRAL GORDILLERA BELT}

The western part of the Central Cordillera belt has major, very young porphyry $\mathrm{Cu}-\mathrm{Mo}-(\mathrm{Au})$ deposits including Cerro Colorado and Cerro
Chorcha in Panama, and Sukut, Rio Nari, Nimaso and others in the Talamanca Cordillera in Costa Rica (Nelson, 1995). Cerro Colorado has been dated at $\sim 4-6 \mathrm{Ma}$ of latest Miocene to Pliocene age (Clark et al., 1977). The other porphyries are undated and some may be older, and mid-Oligocene plutonic rocks are exposed in the Talamanca Cordillera (Drummond et al., 1995). The zonation of the distribution of mineral deposits from epithermal gold in the east to porphyry copper in the western part of the Central Cordillera is related to the collision of the aseismic oceanic Cocos Ridge with the subduction zone in western Panama and eastern Costa Rica. This resulted in uplift to much higher topographic elevations of up to $3,474 \mathrm{~m}$ in Panama (Volcan Barú) and 3,820 m (Cerro Chirripó) in the Talamanca Cordillera of Costa Rica, compared with elevations of about 1,000 $\mathrm{m}$ in the eastern part of the belt, causing deeper erosion to expose the deeper parts of the hydrothermal systems (Kolarsky et al., 1995b). Cerro Colorado itself, which lies to the east side of the subducted ridge and maximum uplift rather than directly over it, has an elevation of almost 1,500 $\mathrm{m}$ and required uplift and erosion of 2-3 km.

The question arises whether aseismic ridge subduction contributed to the formation of the porphyry deposits, as suggested by Cooke et al. (2005) who used Cerro Colorado as an example of the association of giant porphyry deposits with subduction of aseismic ridges. Their model is that topographic and thermal anomalies on the downgoing slab appear to act as tectonic triggers for porphyry formation. Factors that may be important during ridge subduction are flattening of subduction zones, volatile release from the ridge causing metasomatism in the mantle wedge, increase in sulphur flux from metalliferous sediments which may generate oxidized melts capable of transporting $\mathrm{Cu}, \mathrm{Au}$ and $\mathrm{SO}_{2}$ from the mantle to the upper crust (Cooke et al., 2005).

The associated compressional tectonism, rapid uplift and exhumation, reactivation of basement faults, and a hiatus in volcanism associated with crustal thickening would favor the formation of porphyry deposits (Sillitoe, 2010). 
The start of the Cocos Ridge subduction has been dated to about 3.6 Ma by detailed biostratigraphy, with emergence of about $1,000 \mathrm{~m} / \mathrm{My}$ from about 3.6-1.6 Ma on the Pacific, and near 0 $\mathrm{m} / \mathrm{my}$ thereafter, and at $<3 \mathrm{Ma}$ by detailed geomorphological analysis and cooling ages after the cessation of normal volcanism at 9-7 Ma (Morell et al., 2012). Both of these studies indicate a total of about 2,000 $\mathrm{m}$ of uplift which is in agreement with the estimate from Cerro Colorado. However, ridge subduction post-dates the formation of the porphyry copper deposits and so did not play a role in their formation, unless some are younger than Cerro Colorado. The resulting uplift and erosion was, however, responsible for exposing the porphyry deposits and forming supergene copper enrichment.

\subsection{LOW SULPHIDATION EPITHERMAL GOLD IN GENTRAL PANAMA VOLGANIG FIELD}

Low sulphidation epithermal gold mineralization occurs in the Oligocene to early Miocene Central Panama Volcanic Field, as well as widespread occurrences of low temperature, near-neutral $\mathrm{pH}$ hydrothermal minerals such as chalcedony, agate, quartz, calcite, zeolite, pyrite and smectite. Low sulphidation epithermal systems form in extensional settings associated with calc-alkaline to tholeiitic bimodal volcanism (e.g. John, 2001; Sillitoe, 2002; Simmons et al., 2005), which is consistent with extension and basin formation in Central Panama and the Panama Canal Basin and the change from calc-alkaline to tholeiitic volcanism at about $23 \mathrm{Ma}$ (Buchs et al., 2019b), although the youngest magmatism in basic with no evidence for bimodalism.

\subsection{METALLOGENESIS ON AN OGEANIG PLATEAU}

The strong metal endowment of the Panama arcs, including two supergiant $(>10 \mathrm{Mt} \mathrm{Gu})$ porphyry $\mathrm{Cu}$ deposits, may be the result of the formation of the arcs on the edge of an oceanic plateau. The volcanic and intrusive rocks of large igneous provinces have gold concentrations two to thirteen times greater than those formed at mid-ocean ridges as a result of gold and chalcophile element-enriched, mantle plume-related magmas (e.g. Pitcairn, 2011; Webber et al., 2013; Ernst and Jowitt, 2013). In addition, the high degrees of partial melting of the mantle associated with large mantle plume-related LIP events means that the majority of sulphides and chalcophile elements, including $\mathrm{Cu}$ and $\mathrm{Au}$, in the mantle source region may be dissolved into the sulphur-undersaturated silicate magmas (Ernst and Jowitt, 2013).

This thick crust of the oceanic plateau, which is comparable to continental crust, may also have favored the development of porphyry-epithermal systems as soon as subduction was initiated, by allowing a longer path for magmatic differentiation and formation of a fluid and vapor phase. The Azuero arc petrochemistry is typical of high-Fe medium-K arc suites (Buchs et al., 2010). This contrasts with the model of arc evolution with an early tholeiitic stage that did not generate porphyry mineralization, which developed as the arc evolved and became calc-alkaline and enriched in potassium (Kesler et al., 1977).

\subsection{ADAKITIC-LIKE MAGMATISM AND PORPHYRY Cu DEPOSITS}

Adakitic-like magmatism occurs in Oligocene age intrusions (Whattam et al., 2012) and the Quaternary volcanic arc (Defant et al., 1991a; Hidalgo et al., 2011; Morell et al., 2013). Small volume adakitic lavas and domes also occur from 6.5 Ma in western Panama to eastern Costa Rica (Gazel et al., 2011). There is debate about the origin of adakites, which may have formed by slab-melting (Kay, 1978; Defant and Drummond, 1990; Gutscher et al., 2000), and they are significant from a metallogenic point of view due to a proposed relationship with large porphyry copper deposits (Oyarzun et al., 2001). However, adakitic signatures are not exclusively derived by slab melting and can also be formed in normal asthenospheric mantle wedge-derived magmas with high water contents (Richards and Kerrich, 2007; Richards, 2011). This results in a high $\mathrm{Sr} / \mathrm{Y}$ ratio $(>20)$ which indi- 
cates the prospectivity of the magmatic suites for porphyry and epithermal deposits, because these parameters indicate high magmatic water content (Richards, 2011).

The Oligocene Petaquilla batholith and the lower Miocene Majé subvolcanic suite have adakite-like major and trace element abundances including $>15$ wt. $\% \mathrm{Al}_{2} \mathrm{O}_{3},>3.5$ wt. $\% \mathrm{Na}_{2} \mathrm{O},>400$ ppm Sr, <1.9 ppm Yb, <18 ppm Y, Sr/Y ratios up to $>120$, and strongly fractionated REE patterns (Whattam et al., 2012). They are similar to minor adakitic-like andesite intrusions of lower Miocene age (ca $25 \mathrm{Ma}$ ) at Cerro Patacon in the Central Panama Volcanic Field (Rooney et al., 2010) which lies midway between Petaquilla and Majé. Whattam et al. (2012) proposed a model for formation of these adakite-like intrusions by partial melting of lowermost mafic crust above a sub-horizontal slab-tear and break-off in the subducting Farallon Plate that propagated from west to east between 30 and $19 \mathrm{Ma}$. The Oligocene to lower Miocene adakitic-like magmatism is associated with a supergiant porphyry $\mathrm{Cu}$ deposit in the Petaquilla belt, and a porphyry $\mathrm{Cu}$ prospect in the Majé belt. However, Baker et al. (2016) considered that the Petaquilla intrusive rocks have insufficient LREE enrichment, HREE depletion, and Sr/Y (40-60) and $\mathrm{La} / \mathrm{Yb}(<20)$ ratios to be called adakitic-like. They conclude that the Petaquilla porphyries were derived from an enriched, volatile-rich mantle source through fractional crystallization processes with no input from lower crustal melts.

The Quaternary volcanic rocks of the El Valle, La Yeguada, El Barú and Tisingal volcanos have

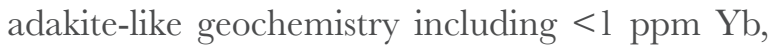
$<6 \mathrm{ppm} \mathrm{Y,} \mathrm{La/Yb} \mathrm{ratios}>15$, and $\mathrm{Sr} / \mathrm{Y}$ ratios >150 (Defant et al., 1991a; Hidalgo et al., 2011). The change of magma chemistry coincides with the cessation of subduction and change to a strike slip plate margin in central and eastern Panama (Kellogg and Vega 1995; Mann 1995; Westbrook et al. 1995), and with a slab tear caused by subduction of the Cocos Ridge beneath Baru-Tisingal (Morell et al., 2013). The high Sr/Y ratio (>150) indicates water-rich magmas and the high prospectivity of the Quaternary volcanic suite for magmatic hydrothermal mineralization, based on the criteria of Richards (2011). The only mineralization known in the Quaternary volcanic rocks is a high sulphidation epithermal Au prospect at Cerro Lloron on El Valle; however, there is no erosion of these stratocones to expose deeper mineralization.

\subsection{DEPOSITS FORMED BY WEATHERING}

A long history of subaerial weathering is shown by the development of lateritic bauxite and iron ore deposits on the Pacific slopes of western Panama, and by the concentration of placer gold in alluvial deposits derived from areas of porphyry-epithermal mineralization. The basalt-covered alluvial terrace deposit at Cocuyo indicates a protracted geomorphological history of channel down-cutting and young volcanism. The shallow marine black sand deposits in the Gulf of Panama were probably formed by a combination of retrograding beaches as Quaternary sea levels rose, with submarine reworking by wave action and longshore drift.

\subsection{SUPERGENE OXIDATION AND ENRIGHMENT}

Oxidation and enrichment to form oxide gold deposits (e.g. Cerro Quema) and supergene copper enrichment zones (e.g. Cerro Colorado, Rio Pito) from epithermal and porphyry protore respectively are other types of deposits formed by weathering. A tropical climate is generally not considered favorable for oxidation and enrichment due to high rainfall washing away the metals and high erosion rates not allowing accumulation; however, oxide and supergene deposits have formed in Panama given the right conditions.

The relatively young uplift and removal of the sedimentary cover exposed the Cerro Quema high sulphidation epithermal $\mathrm{Au}-\mathrm{Cu}$ deposit to erosion and formation of a $150 \mathrm{~m}$ thick oxide zone to form an economic Au oxide deposit. The timing of oxidation is indicated by the tectonic history to be sometime since the late Miocene, and oxidation continues to the present as indicated by actively 
forming ferricrete with anomalous $\mathrm{Cu}$ (Torrey and Keenan, 1994). The formation of a deep oxide zone depended not only on the high porosity and permeability of the rock, but also on a high content of pyrite to produce free acid, the low buffering capacity of the vuggy quartz and advanced argillic alteration to not neutralize the acid, and a wet climate with a long dry season in order for a deep water table to form seasonally, as well as high topographic relief to form a deep water table. The deep oxidation at Cerro Quema also produced a zone of supergene enrichment of copper below the water table with deposition of chalcocite and covellite on hypogene pyrite, enargite, tennantite and chalcopyrite. This required a source of copper in what is now the oxide zone. From this it can be inferred that the oxide zone originally contained copper sulfides presumably in the form of enargite, tetrahedrite and chalcopyrite, similar to the underlying hypogene zone. This indicates that the level of the high sulphidation system preserved is a relatively deep. The original shallow to near surface zone of vuggy quartz and primary gold mineralization has been eroded to expose a zone of Au-Cu mineralization. This has been oxidized to remove $\mathrm{Cu}$ and form an oxide Au body, with re-deposition of $\mathrm{Cu}$ at depth to form a zone of supergene enrichment of $\mathrm{Cu}$ superimposed on primary mineralization.

At the latest Miocene to Pliocene Cerro Colorado porphyry deposit, a 40-150 m thick, supergene chalcocite and covellite enrichment zone containing a resource (measured and indicated) of $102.6 \mathrm{Mt}$ grading $0.724 \% \mathrm{Cu}$ (Kvaerner Metals, 1998) was developed beneath a $0-90 \mathrm{~m}$ thick leached cap. The geometry of these zones mimics the mountain-top and they thin at the edges. The pyrite required to form acid for leaching was probably derived from pyritic sericite and advanced argillic alteration zones in the former lithocap, now eroded. The enrichment formed in the short time of less than $4 \mathrm{Ma}$ as a result of rapid uplift and erosion caused by the subduction of the Cocos Ridge. The nearby Cerro Chorcha deposit has in-situ oxidation to a depth of $135 \mathrm{~m}$ with only minor supergene chalcocite and covellite; the deposit lacks pyrite for leaching since a deeper level of the system in the potassic zone is exposed.

In contrast, the much older Cobre Panama porphyries have no supergene copper enrichment and mineralization is entirely hypogene with deep saprolitic weathering. The exception is the Brazo deposit where the base of the lithocap is preserved and which has a leached cap and a supergene chalcocite enrichment zone of limited extent; the difference here was the abundance of pyrite in the lithocap to generate acid for leaching.

A supergene enrichment zone is also developed on the lower Eocene Rio Pito porphyry $\mathrm{Cu}-\mathrm{Au}$ deposit, where short drill holes in zones of quartz-sericite alteration intersected a zone of supergene copper enrichment between 20-70 m thick, with grades up to $1.0 \% \mathrm{Cu}$ and $0.67 \mathrm{~g} / \mathrm{t} \mathrm{Au}$, with little other information available (UN, 1981; Nelson, 1995). The quartz-sericite alteration indicates a zone with pyrite which was required for leaching.

The depth of oxidation of the low sulphidation epithermal vein and breccia gold deposits is 20-40 $\mathrm{m}$ at Santa Rosa (White, 1994) and 130-140 $\mathrm{m}$ at Remance, and strongly influenced early mining. The hypogene sulphide zones contain fine grained free gold or electrum and generally no base metals, requiring fine grinding and cyanide in leach processing.

Explorers should beware that superficial enrichment of gold in soils and saprolite may take place in the tropical weathering environment in Panama, resulting in continuous, high grade gold values in soil grids and trenches, but which are not reflected in drilling (e.g. Cerro Quema, Pitaloza, Cerro Negro). This is believed to be due to a residual concentration or lag effect of gold or gold-bearing quartz in soil, rather than a chemical effect. Torrey and Keenan (1994) described wide zones grading 4-6 g/t $\mathrm{Au}$ in trenches at Cerro Quema, which drilling indicated to be near-surface only. This effect was strongest over residual silica alteration and was interpreted to be due to volume reduction from the leaching of up to $35 \%$ pyrite causing solution collapse to leave rubbly zones up to $15-30 \mathrm{~m}$ thick. 
These examples show that significant oxidation and enrichment can take place in high rainfall tropical climates. One of the key requirements is the presence of abundant pyrite to form free acid for leaching. High pyrite contents typically occur in zones of sericite (phyllic) and advanced argillic alteration in the upper parts of porphyry systems and the overlying lithocaps and high sulphidation epithermal deposits.

The age of the deposits in the examples ranges from Eocene to Pliocene, so age and time are not contributing factors. The age of oxidation and enrichment is $<4 \mathrm{Ma}$ at Cerro Colorado, from late Miocene or later to the present day at Cerro Quema, and unknown at Rio Pito: where known, oxidation is young and is related to tectonic uplift, thus the tectonic and geomorphological history of deposits is important.

\section{Conclusions}

The mineral deposits and prospects of Panama are dominated by epithermal $\mathrm{Au}$ and porphyry $\mathrm{Cu}-\mathrm{Mo} \pm(\mathrm{Au}-\mathrm{Ag})$ systems including two supergiant porphyry deposits, which formed in multiple volcanic-intrusive island arcs from the Campanian to Quaternary. In addition, submarine exhalative deposits of Si-Mn-(Fe) oxides and $\mathrm{Au}-\mathrm{Cu}-\mathrm{Zn}$ volcanic massive sulphide mineralization occur in the submarine parts of the Early Arc. The arcs and mineral deposits were developed on the western, trailing edge of a large igneous province oceanic plateau, the Caribbean Large Igneous Province, which may have contributed to the metal source in Panama. An Early Arc of Campanian to Eocene age was followed by a Middle Arc of Oligocene to lower Miocene age and a Later Arc of Miocene to Quaternary age, each of which can be divided into various metallogenic belts. Displacements of the Early Arc and its metallogenic belts were caused by collision of the arc with the South American plate followed by plate reorganization with the breakup of the Farallon Plate into the Nazca and Cocos Plates. The development of the metallogenic belts took place in an island arc during the prolonged collision with a continent, related to the complex interaction with multiple oceanic plates and an oceanic plateau, resulting in deformed, displaced and discontinuous belts with contrasting younging trends, rather than simple linear belts.

\section{Acknowledgements}

Thanks are due to the many geologists who I have worked with and discussed the mineral deposits and geology of Panama with over the years, and in particular to Marc Boisvert, Fred Speidel, Carlos Carrasco, Darren King and Colin Burge of Minnova/Inmet, Carl Nelson and David Buchs. The figures were drafted by José Cornejo Jr. The manuscript benefitted from reviews by Camilo Montes and Fred Speidel, and from editing by Carl Nelson.

\section{References}

Anon, 1882, Gold on the Isthmus of Panama: Engineering and Mining Journal, 34, September, 173.

Archibald, R. D., Gibbs, B. L., Kunter, R. S., Martin, M. D., Solano-Rico, B., 2011, Molejon project, NI 43-101 technical report, Donoso District, Colon Province, Republic of Panama. NI 43-101 technical report by Behre Dolbear \& Company (USA) Inc. for Petaquilla Minerals Ltd., April 2011.

Archibald, R. D., Gibbs, B. L., Kunter, R. S., Martin, M. D., Solano-Rico, B., 2012, Molejon project, NI 43-101 technical report, Donoso District, Colon Province, Republic of Panama. NI 43-101 technical report by Behre Dolbear \& Company (USA) Inc. for Petaquilla Minerals Ltd., May 2012.

Baker, M. J., Hollings, P., Thompson, J. A., Thompson, J. M., Burge, C., 2016, Age and geochemistry of host rocks of the Cobre Panama porphyry $\mathrm{Cu}-\mathrm{Au}$ deposit, central Panama: Implications for Paleogene evolution of the Panamanian magmatic 
arc: Lithos, 248-251, 40-54. https://doi. org/10.1016/j.lithos.2016.01.014

Barat, F., MercierdeLépinay, B., Sosson, M., Müller, C., Baumgartner, P. O., Baumgartner-Mora, G., 2014, Transition from the Farallon Plate subduction to the collision between South and Central America: Geological evolution of the Panama Isthmus: Tectonophysics, 622, 145-167. https://doi.org/10.1016/j. tecto.2014.03.008

Barbosa-Espitia, A. A., Kamenov, G. D., Foster, D. A., Restrepo-Moreno, S. A., Pardo-Trujillo, A., 2019, Contemporaneous Paleogene arcmagmatism within continental and accreted oceanic arc complexes in the northwestern Andes and Panama: Lithos, 348-349, 105185. https://doi.org/10.1016/j. lithos.2019.105185

Blas Aritio, L., 2014, Vasco Núñez de Balboa, La Crónica de los Cronistas de Indias: Panamá, Panamá, Ediciones Balboa, 422 p.

Brandes, C., Astorga, A., Blisniuk, P., Littke, R., Winsemann, J., 2007, Anatomy of anticlines, piggy-back basins and growth strata: A case study from the Limón Fold-and-thrust belt, Costa Rica. In,Nichols,G.,Williams, E., Paola, C., (eds.), Sedimentary processes, environments and basins: A tribute to Peter Friend: International Association of Sedimentologists Special Publication 38, Oxford, England, Blackwell Science, 91-110. Buchs, D. M., Arculus, R. J., Baumgartner, P. O., Baumgartner-Mora, C., Ulianov, A., 2010, Late Cretaceous arc development on the SW margin of the Caribbean Plate: Insights from the Golfito, Costa Rica, and Azuero, Panama, complexes: Geochemistry Geophysics Geosystems, 11, Q07S24. https://doi.org/10.1029/2009GC002901

Buchs, D. M., Arculus, R. J., Baumgartner, P. O., Ulianov, A., 2011 a, Oceanic intraplate volcanoes exposed: Examples from seamounts accreted in Panama: Geology, 39 (4), 335-338.https://doi.org/10.1130/ G31703.1
Buchs, D. M., Baumgartner, P. O., BaumgartnerMora, C., Flores, D., Bandini, A. N., 2011b, Upper Cretaceous to Miocene tectonostratigraphy of the Azuero area (Panama) and the discontinuous accretion and subduction erosion along the Middle American margin: Tectonophysics, 512, 31-46.https://doi.org/10.1016/j. tecto.2011.09.010

Buchs, D. M., Irving, D., Coombs, H., Miranda, R., Wang,J., Coronado, R., Arrocha, R., Lacerda, M., Goff, C., Almengor, E., Portugal, E., Franceschi, P., Chichaco, E., Redwood, S. D., 2019a, Volcanic contribution to emergence of Central Panama in the Early Miocene: Scientific Reports, 9, 1417, 1-16. https://doi. org/10.1038/s41598-018-37790-2

Buchs, D. M., Coombs, H., Irving, D., Wang, J., Koppers, A., Miranda, R., Coronado, M., Tapia, A., Pitchford, S., 2019b, Volcanic shutdown of the Panama Canal area following breakup of the Farallon plate: Lithos, 334-335, 190-204. https://doi. org/10.1016/j.lithos.2019.02.016

Bush, M. B., Colvinaux, P. A., 1990, A pollen record of a complete glacial cycle from lowland Panama: Journal of Vegetation Science, 1, 105-118. https://doi.org/10.2307/3236060

Byington, C. B., Russell, M. R., 2001, Economic geology and ore controls of the Santa Rosa mine - an integrated structural analysis approach: Cañazas, Veraguas, Republic of Panama: Society of Economic Geologists Special Publication 8, 317-329.

Camacho, E., Hutton, W., Pacheco, J. F., 2010, A New Look at Evidence for a Wadati-Benioff Zone and Active Convergence at the North Panama Deformed Belt: Bulletin of the Seismological Society of America, 100, 343348.https://doi.org/10.1785/0120090204

Camus, Y., 2013, NI 43-101 Palmilla Deposit, Resource Update, Rio Belencillo Zone 1 Concession, Colon Province, Panama: NI 43101 technical report by SGS Canada Inc. for Petaquilla Minerals Ltd., 29 October 2013. 
Cardona, A., León, S., Jaramillo, J. S., Montes, C., Valencia, V. Vanegas, J., Bustamante, C., Echeverri, S., 2018, The Paleogene arcs of the northern Andes of Colombia and Panama: Insights on plate kinematic implications from new and existing geochemical, geochronological and isotopic data: Tectonophysics, 749, 88-103. https:// doi.org/10.1016/j.tecto.2018.10.032

Carles, R. D., 1962, Oro en Panamá: Revista Lotería, 7 (77), 40-41.

Castillero Calvo, A., 1967a, Los placeres auríferos de Concepción, in, Castillero Calvo, A., Estructuras Sociales y Económicas y de Veragua desde sus origenes históricos, Siglos XVI y XVII: Panamá, Editora Panamá, 53-87.

Castillero Calvo, A., 1967b, Las Sabanas y la sociedad "señorial", in, Castillero Calvo, A., Estructuras Sociales y Económicas y Sociales de Veragua desde sus origenes históricos, Siglos XVI y XVII: Panamá, Editora Panamá, 91-137.

Castillero Calvo, A., 2008, Los Metales Preciosas y la primera globalización: Panamá, Imprenta Editora Novo Art. 272 p.

Castillero Calvo, A., 2019, El oro y las perlas en la economía colonial, in, Castillero Calvo, A. (ed.), Nueva Historia General de Panamá: Panamá, Ciudad Comisión 500 Años de Fundación de la de Panamá, I(III), El Orden Colonial, 1541-1580.

Cediel, F., Shaw, R. P. (eds), 2019, Geology and Tectonics of Northwestern South America: The Pacific-Caribbean-Andean Junction: Cham, Switzerland, Springer International Publishing AG. https://doi. org/10.1007/978-3-319-76132-9

Cediel, F., Shaw, R. P., Cáceres, C., 2003, Tectonic Assembly of the Northern Andean Block, in Bartolini, C., Buffler, R. T., Blickwede, J., (eds), The Circum-Gulf of Mexico and the Caribbean: Hydrocarbon habitats, basin formation, and plate tectonics: American Association of Petroleum Geologists Memoir, 79, 815-848.
Chibas, E. J., 1898, The Darien Gold-Mining Region in Colombia: Engineering Magazine, October 1898, 49-63.

Clark, A. H., 1979, Potassium-argon age of the Cerro Colorado porphyry copper deposit, Panama - a reply: Economic Geology, 74, 695.

Clark, A. H., 1993, Are outsize porphyry copper deposits either anatomically or environmentally distinctive?: Society of Economic Geologists Special Publication, 2, 213-282.

Clark, A. H., Farrar, E., Kents, P., 1977, Potassiumargon age of the Cerro Colorado porphyry copper deposit, Panama: Economic Geology, 72, 1154-1158. https://doi.org/10.2113/ gsecongeo.72.6.1154

Coates, A. G., Collins, L. S., Aubry, M.-P., Berggren, W. A., 2004, The Geology of the Darien, Panama, and the late MiocenePliocene collision of the Panama arc with northwestern South America: Geological Society of America Bulletin, 116, 1327-1344. https://doi.org/10.1130/B25275.1

Cooke, D. R., Hollings, P., Walshie, J. L., 2005, Giant porphyry deposits: characteristics, distribution and tectonic controls: Economic Geology, 100, 801-818. https://doi. org/10.2113/gsecongeo.100.5.801

Corral, I., 2013, Geology and metallogeny of the Cerro Quema Au-Cu deposit (Azuero Peninsula, Panama): Barcelona, Spain, Universitat Autònoma de Barcelona, PhD thesis, $192 \mathrm{p}$.

Corral, I., Griera, A., Gómez-Gras, D., Corbella, M., Cardellach, E., 2010, Geochemical evolution of the Panamanian CretaceousPaleogene volcanic arc: Insights from the Azuero Peninsula, SW Panama: Geogaceta, 49, 79-82.

Corral, I., Griera, A., Gómez-Gras, D., Corbella, M., Canals, A., Pineda-Falconett, M., Cardellach, E., 2011, Geology of the Cerro Quema Au-Cu deposit (Azuero Peninsula, Panama): Geologica Acta, 9, 481-498. https://doi.org/10.1344/105.000001742 
Corral, I., Corbella, M., Griera, A., Gómez-Gras, D., Cosca, M. A., Cardellach, E., 2012, Age of the Cerro Quema Au-Cu deposit (Azuero Peninsula, Panama): Insights from biostratigraphy and Ar/Ar geochronology: Geo-Temas, 13, 411-414.

Corral, I., Gómez-Gras, D., Griera, A., Corbella, M., Cardellach, E., 2013, Sedimentation and volcanism in the Panamanian Cretaceous intra-oceanic arc and fore-arc: insights from the Azuero Peninsula (SW Panama): Bulletin de la Société Géologique de France, 185, 35-45.

Corral, I., Cardellach, E., Corbella, M., Canals, A., Gómez-Gras, D., Griera, A., Cosca, M. A., 2016, Cerro Quema (Azuero Peninsula, Panama): Geology, Alteration, Mineralization, and Geochronology of a Volcanic Dome-Hosted High-Sulfidation $\mathrm{Au}-\mathrm{Cu}$ Deposit: Economic Geology, 111, 287-310. https://doi.org/10.2113/ econgeo.111.2.287

Corral, I., Cardellach, E., Corbella, M., Canals, A., Griera, A., Gómez-Gras, D., Johnson, C. A., 2017, Origin and evolution of mineralizing fluids and exploration of the Cerro Quema $\mathrm{Au}-\mathrm{Cu}$ deposit (Azuero Peninsula, Panama) from a fluid inclusion and stable isotope perspective: Ore Geology Reviews, 80, 947-960.https://doi.org/10.1016/j. oregeorev.2016.09.008

Corral, I., Corbella, M., Gómez-Gras, D., Griera, A., 2018, Trace-metal content of Cerro Quema Au-Cu deposit (Azuero Peninsula, Panama): Implications for exploration: Boletín de la Sociedad Geológica Mexicana, 70, 549-565. http://dx.doi.org/10.18268/ BSGM2018v70n2a14

de Boer, J. Z., Defant, M. J., Stewart, R. H., Restrepo, J. F., Clark, L. F., Ramirez, A. H., 1988, Quaternary calc-alkaline volcanism in western Panama: Regional variation and implication for plate tectonic framework: Journal of South American Earth Sciences, 1, 275-293. https://doi. org/10.1016/0895-9811(88)90006-5 de Boer, J. Z., Defant, M. J., Stewart, R. H., Bellon, H., 1991, Evidence for active subduction below western Panama: Geology, 19, 649-652. https:// doi.org/10.1130/0091-7613(1991)019<0649:EF $\mathrm{ASBW}>2.3 . \mathrm{CO} ; 2$

Defant, M.J., Drummond, M. S., 1990, Derivation of some modern arc magmas by melting of young subducted lithosphere: Nature, 347, 662-665.https://doi.org/10.1038/347662a0

Defant, M. J., Clark, L. F., Stewart, R. H., Drummond, M. S. de Boer, J. Z., Maury, R. C., Bellon, H., Jackson, T. E., Restrepo, J. F., 1991a, Andesite and dacite genesis via contrasting processes: the geology and geochemistry of El Valle Volcano, Panama: Contributions to Mineralogy and Petrology, 106, 309-324. https://doi.org/10.1007/ BF00324560

Defant, M. J., Richerson, P. M., De Boer, J. Z., Stewart, R. H., Maury, R. C., Bellon, H., Drummond, M. S., Feigenson, M. D., Jackson, T. E., 199 1b, Dacite genesis via both slab melting and differentiation: petrogenesis of La Yeguada volcanic complex, Panama: Journal of Petrology, 32, 1101-1142. https:/ / doi.org/10.1093/petrology/32.6.1101

del Giudice, D., 1965, Los depositos goetiticos de La Mesa, Provincia de Veraguas, Republica de Panama: Report, Panamá, Dirección General de Recursos Minerales, DDG/11.

del Giudice, D., Recchi, G., 1969, Geología del area del projecto minero de Azuero: Report, Panama, United Nations, 48 p.

Dirección General de Recursos Minerales (DGRM), 1991, Mapa Geológico, Republica de Panamá, 1:250,000 scale: Panamá, Panamá, Dirección General de Recursos Minerales, 8 sheets.

Druecker, M. D., Sandefur, R. L., 2008, Update Report on the Cerro Chorcha Porphyry Copper Project, Chiriqui and Bocas del Toro Provinces, Republic of Panama: NI 43-101 technical report for Bellhaven Copper \& Gold Inc. and Dominion Minerals Corp.

Drummond, M.S., Bordelon, M., de Boer, J.Z., Defant, M.J., Bellon, H., Feigenson, M.D., 
1995, Igneous petrogenesis and tectonic setting of plutonic and volcanic rocks of the Cordillera de Talamanca, Costa RicaPanama, Central American arc: American Journal of Science, 295, 875-919. http:// dx.doi.org/10.2475/ajs.295.7.875

Ernst, R. E., Jowitt, S. M., 2013, Large igneous provinces (LIP) and metallogeny: Society of Economic Geologists Special Publication, 17, 17-51.

Farris, D. W., Jaramillo, G., Bayona, G., RestrepoMoreno, S. A., Montes, C., Cardona, A., Mora, A., Speakman, R. J., Glascock, M. D., Valencia, V., 2011, Fracturing of the Panamanian Isthmus during initial collision with South America: Geology, 39, 10071010. https://doi.org/10.1130/G32237.1

Farris, D. W., Cardona, A., Montes, C., Foster, D., Jaramillo, C., 2017, Magmatic evolution of Panama Canal volcanic rocks: A record of arc processes and tectonic change: PLos ONE, 12, e0176010. http://dx.doi.org/10.1371/ journal.pone.0176010

Ferenčić, A., 1971, Metallogenic provinces and epochs in Southern Central America: Mineralium Deposita, 6, 77-88. https://doi. org/10.1007/BF00207119

Fernandez, R. R., Martin, R., Bikerman, D., 1997, Managing the Santa Rosa Open-Pit, Heap-Leach Gold Project: JOM, Journal of the Minerals, Metals and Materials Society, 49, 15-19. https://doi.org/10.1007/ BF02914868

Fisher, S. P., and Pessagno, E. A., Jr., 1965, Upper Cretaceous strata of Northwestern Panama: American Association of Petroleum Geologists Bulletin, 49, 433-444. https://doi.org/10.1306/ A6633630-16C0-11D7-8645000102C1865D

Foley, J. Y., Light, T. D., Nelson, S. W., Harris, R. A., 1997, Mineral Occurrences Associated with Mafic-Ultramafic and Related Alkaline Complexes in Alaska, in Goldfarb, R. J., Miller, L. D. (eds), Mineral Deposits of
Alaska: Economic Geology Monograph, 9, 396-449.

Folk, P. G., 2004a, Report on the Pitaloza Project, Herrera and Los Santos Provinces, Republic of Panama: NI 43-101 technical report for Bellhaven Ventures Inc., 22 p.

Folk, P. G., 2004b, Report on the Rio Liri Project, Veraguas and Chiriqui Provinces, Republic of Panama: NI 43-101 technical report for Bellhaven Ventures Inc., 22 p.

Folk, P. G., 2004c, Report on Veraguas Project, Veraguas Province, Republic of Panama: Higui (Zone 1), Hatillos (Zone 2), San Pedrito: NI 43-101 technical report for Bellhaven Ventures Inc., 23 p.

Folk, P. G., 2005, Report on the Chorcha Project, Chiriqui and Bocas del Toro Provinces, Republic of Panama: NI 43-101 technical report for Bellhaven Ventures Inc., 64 p.

Foster, D. F., 1939, Report on San Jose Hill, Darien, R. de Panama: Report for Panama Corporation (Canada) Ltd., University of Wyoming, American Heritage Center, Thayer Lindslay Papers, Box 204, F. 1, 7 p.

Franklin, J. M., Gibson, H. L., Jonasson, I. R., Galley, A. G., 2005, Volcanogenic massive sulfide deposits: Economic Geology 100th Anniversary Volume, 523-560.

Gazel, E., Hoernle, K., Carr, M. J., Herzberg, C., Saginor, I., van den Bogaard, P., Hauff, F., Feigenson, M., Swisher III, C., 2011, Plume-subduction interaction in southern Central America: mantle upwelling and slab melting: Lithos 121, 117-134. https://doi. org/10.1016/j.lithos.2010.10.008

Gray, F., Hammarstrom, J. M., Ludington, S., Zürcher, L., Nelson, G. E., Robinson, G. R., Miller, R. J., Moring, B. C., 2010, Porphyry Copper Assessment of Central America and the Caribbean Basin: U.S. Geological Survey Scientific Investigations Report 2010-5090$1,83 \mathrm{p}$.

Gray, D., Lawlor, M., Stone, R., 2019, Cobre Panamá Project, Colón Province, Republic 
of Panamá, NI 43-101 Technical Report: NI 43-101 technical report by First Quantum Minerals Ltd.

Griggs, J. C., 2005, The Archaeology of Central Caribbean Panama: Austin, Texas, The University of Texas at Austin, $\mathrm{PhD}$ thesis, xxix +420 p.

Gutscher, M.-A., Maury, R., Eissen, J.-P., Bourdon, E., 2000, Can slab melting be caused by flat subduction?: Geology, 28, 535-538.https://doi.org/10.1130/0091$7613(2000) 28<535$ : C S MB CB > 2. 0 . $\mathrm{CO} ; 2$

Hargreaves, D., 1974, Feasibility studies outline Cerro Colorado development: Mining Magazine, 131(2), 86-97.

Hedenquist, J. M., 2010, Comments on the Pitaloza and Cerro Viejo projects, Azuero Peninsula, Panama: Report for Bellhaven Copper \& Gold Inc., www.bellhavencg.com, 3 August 2010.

Hidalgo, P. J., Vogel, T. A., Rooney, T. O., Currier, R. M., Layer, P. W., 2011, Origin of silicic volcanism in the Panamanian arc: evidence for a two-stage fractionation process at $\mathrm{El}$ Valle volcano: Contributions to Mineralogy and Petrology, 162, 1115-1138. https://doi. org/10.1007/s00410-011-0643-2

Huhta, J. V., 1991, Discovery of Porphyry Copper Mineralization at Cerro Petaquilla, in Porphyry Copper, Molybdenum and Gold Deposits, Volcanogenic Deposits (Massive Sulphides), and Deposits in Layered Rocks: American Institute of Mining, Metallurgical and Petroleum Engineering, Case Histories of Mineral Discoveries, 3, 39-40.

Hull, C. F. H., 1940, Panama Corporation (Canada) Limited: Report for Panama Corporation (Canada) Ltd., University of Wyoming, American Heritage Center, Thayer Lindslay Papers, Box 204, Folder 1, $8 \mathrm{p}$.

Ireland, T., Benavides, S., Halley, S., Burge, C., Imaña, M., Trott, M., Andersson, S., 2014, The geology and exploration footprint of the Cobre Panamá porphyry copper deposits (abstract), in Society of Economic Geologists SEG 2014 Congress: Keystone, Colorado.

Issigonis, M.J., 1982, Two stages of alteration and $\mathrm{Cu}-\mathrm{Mo}$ mineralization at Cerro Colorado, Panama: Transactions of the Institution of Mining \& Metallurgy, Section B, Applied Earth Sciences, 91, B219-B223.

John, D. A., 2001, Miocene and early Pliocene epithermal gold-silver deposits of the northern Great Basin, western United States: Characteristics, distribution and relation to magmatism: Economic Geology, 96, 1827-1853. https://doi.org/10.2113/ gsecongeo.96.8.1827

Kay, R. W., 1978, Aleutian magnesian andesites: Melts from subducted Pacific ocean crust: Journal of Volcanology and Geothermal Research, 4, 117-132. https://doi. org/10.1016/0377-0273(78)90032-X

Kellogg,J. N., Vega, V., 1995, Tectonic development of Panama, Costa Rica, and the Colombian Andes: Constraints from Global Positioning System geodetic studies and gravity, in Mann, P. (ed), Geologic and Tectonic Development of the Caribbean Plate Boundary in Southern Central America: Geological Society of America Special Paper, 295, 75-90.

Kellogg, J. N., Franco Camelio, G. B., Mora-Páez, H., 2019, Cenozoic tectonic evolution of the North Andes with constraints from volcanic ages, seismic reflection, and satellite geodesy, in Horton, B. K., Folguera, A. (eds), Andean Tectonics: Elsevier, 69-102. https://doi. org/10.1016/B978-0-12-816009-1.00006-X

Kents, P., 1975, Geology and mineralization of the Cerro Colorado copper-porphyry deposit, Republic of Panama: AIME Preprint, 75-S-2.

Kesler, S. E., Sutter, J. F., Issigonis, M. J., Jones, L. M., Walker, R. L., 1977, Evolution of Porphyry Copper Mineralization in an Oceanic Island Arc: Panama: Economic Geology, 72, 1142-1153. https://doi. org/10.2113/gsecongeo.72.6.1142

Kolarsky, R. A., Mann, P., Monechi, S., 1995a, Stratigraphic Development of Southwestern Panama as Determined from Integration of 
Marine Seismic Data and Onshore Geology, in, Mann, P., (ed), Geologic and Tectonic Development of the Caribbean Plate Boundary in Southern Central America: Geological Society of America Special Paper, 295, 159-187.

Kolarsky, R. A., Mann, P., Montero, W., 1995b, Island arc response to shallow subduction of the Cocos Ridge, Costa Rica, in, Mann, P. (ed.), Geologic and Tectonic Development of the Caribbean Plate Boundary in Southern Central America: Geological Society of America Special Paper, 295, 235-262.

Kuÿpers, E. P., Denyer, P., 1979, Volcanic exhalative manganese deposits of the Nicoya ophiolite complex, Costa Rica: Economic Geology, 74, 672-692. https://doi.org/10.2113/ gsecongeo.74.3.672

Kvaerner Metals, 1997, Cerro Colorado Copper Project. Leach, SX-EW Prefeasibility Study: Report for PanaCobre S. A., Panama.

Kvaerner Metals, 1998, Cerro Colorado Copper Project. Leach, SX-EW Feasibility Study: Report for PanaCobre S. A., Panama.

Lach-Szyrma, G. W., 1909, The Darien, Republic of Panama: The South American Journal, 14 August 1909, 177.

Leistel, J. M., Marcoux, E., Deschamps, Y., 1998, Chert in the Iberian Pyrite Belt: Mineralium Deposita, 33, 59-81. https:// doi.org/10.1007/s001260050133

Linn, K. O., Wieselmann, E. A., Galay, I., Harvey, J. J. T., Tufino, G. F., Winfield, W. D., 1981a, Geology of Panama's Cerro Colorado Porphyry Copper Deposit: Part 1: History and Setting: Mineral Energy Resources, Colorado School of Mines, 24(5), 1-14.

Linn, K. O., Wieselmann, E. A., Galay, I., Harvey, J. J. T., Tufino, G. F., Winfield, W. D., 1981b, Geology of Panama's Cerro Colorado Porphyry Copper Deposit: Part 2: Structure, Mineralization and Mineral Inventory: Mineral Energy Resources, Colorado School of Mines, 24(6), 1-14.

Lissinna, B., 2005, A profile through the Central American Landbridge in western Panama:
115 Ma Interplay between the Galápagos hotspot and the Central American subduction zone: Kiel, Germany, Christian-AlbrechtsUnivesität, $\mathrm{PhD}$ thesis. $102 \mathrm{p}$.

Lonsdale, P., Klitgord, K. M., 1978, Structure and tectonic history of the eastern Panama Basin: Geological Society of America Bulletin, 89, 981-999. https://doi.org/10.1130/0016$7606(1978) 89<981:$ SATHOT $>2.0$. $\mathrm{CO} ; 2$

Low, V. F. S., 1931, Panama: The Mining Magazine, 44, 201-209.

Lydon, J. W., 1984, Volcanogenic massive sulphide deposits, Part 1 - A descriptive model: Geoscience Canada, 11, 195-202.

MacDonald, D. F., 1915, Some Engineering Problems of the Panama Canal in their Relation to Geology and Topography: U. S. Bureau of Mines Bulletin, 86.

Mann, P. (ed.), 1995, Geologic and Tectonic Development of the Caribbean Plate Boundary in Southern Central America: Geological Society of America Special Paper, $295 \mathrm{p}$.

Mann, P., Kolarsky, R. A., 1995, East Panama deformed belt: Structure, age, and neotectonic significance, in, Mann, P. (ed), Geologic and Tectonic Development of the Caribbean Plate Boundary in Southern Central America: Geological Society of America Special Paper, 295, 111-130.

Mena García, C., 201 1, El oro del Darién: Entradas y cabalgadas en la conquista de Terra Firme (1509-1525): Fundación Pública Andaluza, Centro de Estudios Andaluces, Seville and Consejo Superior de Investigaciones Científicas, Madrid.

Mende, A., 2001, Sedimente und Architektur der Forearc-und Backarc-Becken von SüdostCosta Rica und Nordwest-Panamá: PhD thesis, University of Stuttgart, Stuttgart, Germany, Profil, 19, 1-130.

Méndez, A., 2013, Reseña histórica de la actividad minera en Panamá. Historical summary of mining activity in Panama. Planeta Minero, 12, 4-8. 
Medina Molero, M., Corral, I., Cardellach, E., 2014, Estudio mineralógico del depósito de Au de Pitaloza (Península de Azuero, Panamá): Revista de la Sociedad Española de Mineralogía, 19, 2.

Mérida, J. L., 1973, Contribución a la historia de la exploración y explotación minera en Panamá: Panama, Dirección General de Recursos Minerales (DGRM).

Montes, C., Cardona, A., Bayona, G., Farris, D., 2011, Field Trip Guide: Evidence for middle Eocene and younger emergence in Central Panama: Panama, Panama, Smithsonian Tropical Research Institute.

Montes, G., Bayona, G., Cardona, A., Buchs, D. M., Silva, G. A., Morón, S., Hoyos, N., Ramírez, D. A., Jaramillo, C. A., Valencia, V., 2012a, Arc-continent collision and orocline formation: Closing of the Central American seaway: Journal of Geophysical Research, 117, B04105, https://doi. org/10.1029/2011JB008959

Montes, C., Cardona, A., McFadden, R., Morón, S. E., Silva, C. A., Restrepo-Moreno, S., Ramírez, D. A., Hoyos, N., Wilson, J., Farris, D., Bayona, G. A., Jaramillo, C. A., Valencia, V., Bryan, J., Flores, J. A., 2012b, Evidence for middle Eocene and younger land emergence in central Panama: Implications for Isthmus closure: Geological Society of America Bulletin, 124, 780-799. https://doi. org/10.1130/B30528.1

Montes, C., Cardona, A., Jaramillo, C., Pardo, A., Silva, J. C., Valencia, V., Ayala, C., Pérez-Angel, L. C., Rodriguez-Parra, L. A., Ramirez, V., Niño, H., 2015, Middle Miocene Closure of the Central American Seaway: Science, 348(6231), 226-229. https://doi. org/10.1126/science.aaa2815

Montes, G., Rodriguez-Corcho, A.F., Bayona, G., Hoyos, N., Zapata, S., Cardona, A., 2019, Continental margin response to multiple arccontinent collisions: The northern AndesCaribbean margin: Earth-Science Reviews, 198, 102903. https://doi.org/10.1016/j. earscirev.2019.102903
Morell, K.D., Kirby, E., Fisher, D.M., van Soest, M., 2012, Geomorphic and exhumational response of the Central American volcanic arc to Cocos Ridge subduction: Journal of Geophysical Research, 117, no. B04409. https://doi.org/10.1029/2011JB008969

Morell, K. D., Gardner, T. W., Fisher, D. M., Idleman, B. D., Zellner, H. M., 2013, Active thrusting, landscape evolution, and late Pleistocene sector collapse of Barú Volcano above the Cocos-Nazca slab tear, southern Central America: Geological Society of America Bulletin, 125, 1301-1318. https:// doi.org/10.1130/B30771.1

Muller, S. C., 2007, Resource estimate of the Molejon gold deposit through September 2007, Colon Province, Panama: NI 43-101 technical report by ATT Mining Services for Petaquilla Gold Ltd.

Nelson, G. E., 1995, Porphyry copper deposits of Southern Central America, in, Pierce, F. W., Bolm, J. G. (eds), Porphyry copper deposits of the American Cordillera: Arizona Geological Society Digest, 20, 553-565.

Nelson, G. E., 2001, Gold Mineralization in Dome Fields of the Veraguas Belt, Panama: Society of Economic Geologists Special Publication, 8, 307-316.

Nelson, C. E., 2007, Metallic Mineral Resources, in Bundschuh, J., Alvarado, G. (eds), Central America: Geology, Resources and Hazards. Leiden, The Netherlands, CMC Press / Balkema, 885-915.

Nelson, C. E., Ganoza, J., 1999, Mineralización de oro en la franja aurífera de Veraguas, Panama: Revista Geológica de América Central, 22, 87-100.https://doi.org/10.15517/RGAC. V0I22.8589

Oller, J., 1933. La Industria Minera en Panama: Panamá, Biblioteca Cultura Nacional, 19, 193-214.

Oller, J., 1975. La Industria Minera en Panama: Panamá, 2nd. ed., 48 p.

Oyarzún, R., Márquez, A., Lillo, J., López, I., Rivera, S., 2001, Giant versus small porphyry copper deposits of Cenozoic age in 
northern Chile: adakitic versus normal calcalkaline magmatism: Mineralium Deposita, 36, 794-798. https://doi.org/10.1007/ s001260100205

Patterson, S. H., 1967, Bauxite Reserves and Potential Aluminum Resources of the World: United States Geological Survey Bulletin, 1228.

Patterson, S. H., Kurtz, H. F., Olson, J. C., Neeley, G. L., 1986, World Bauxite Resources: Geology and Resources of Aluminum: United States Geological Professional Paper, 1076-B, B1-B151. https://doi.org/10.3133/ pp 1076B

Perelló, J., García, A., Creaser, R. A., 2020. Porphyry-related high-sulfidation mineralization early in Central American Arc Development: Cerro Quema deposit, Azuero Peninsua, Panama: Boletín de la Sociedad Geológica Mexicana, 72(3), A260719. http://dx.doi.org/10.18268/ BSGM2020v72n3a260719

Pindell, J., Kennan, L., Maresch, W. V., Stanek, K. -P., Draper, G., Higgs, R., 2005, Platekinematics and crustal dynamics of circumCaribbean arc-continent interactions: Tectonic controls on basin development in Proto-Caribbean margins, in, Avé Lallemant, H. G., Sisson, V. B., (eds.), Caribbean-South American plate interactions, Venezuela: Geological Society of America Special Paper, 394, 7-52.

Pitcairn, I. K., 2011, Background concentrations of gold in different rock types: Applied Earth Science Transactions of the Institution of Mining and Metallurgy Section B, 120, 31-38. https://doi.org/10.1179/17432758 11 Y.0000000021

Posada, F., 1898, Directorio General de la Giudad de Panamá: Panamá, Imprenta Star and Herald.

Puritch, E. J., Sutcliffe, R. H., Wu, Y., Armstrong, T., Yassa, A., 2012, Technical Report and Mineral Resource Estimate on the Cerro Quema Project, Los Santos Province, Panama: NI 43-101 technical report by $\mathrm{P}$
\& E Mining Consultants Inc. for Pershimco Resources Inc.

Quirós, J. L., 1962, Los Minerales de Panama: Panamamerica, April 1962, 6 p.

Quirós, J. L., 1975, Apuntes Sobre Recursos Minerales en Panama: Panamá, Panamá, Direccion General de Recursos Minerales.

Ramirez, D. A., Foster, D. A., Min, K., Montes, C., Cardona, A., Sadove, G., 2016, Exhumation of the Panama basement complex and basins: Implications for the closure of the Central American seaway: Geochemistry, Geophysics, Geosystems, 17, 1758-1777. https://doi.org/10.1002/2016GC006289

Redwood, S.D., 2010, Metallogenesis and Arc Evolution of Panama and NW Colombia (abstract), in Montes, C., Cardona, A., García-Casco, A. (eds), Subduction Zones of the Caribbean Workshop: Panama, Panama, Smithsonian Tropical Research Institute.

Redwood, S.D., 2019, The Geology of the Panama-Chocó Arc, in Cediel, F., Shaw, R. P. (eds), Geology and Tectonics of Northwestern South America - The Pacific-CaribbeanAndean Junction: Cham, Switzerland, Springer International Publishing AG, 901-932.

Redwood, S.D., 2020, The history of mining and mineral exploration in Panama: From PreColumbian gold mining to modern copper mining: Boletín de la Sociedad Geológica Mexicana, 72 (3), A180720. http://dx.doi. org/10.18268/BSGM2020v72n3a180720

Redwood, S. D., Bryan, J. R., Buchs, D. M., Burge, C., 2021, Late Eocene Biostratigraphic Age for Andesitic Volcanic Host Rocks Formed in an Island Environment at the Cobre Panama Porphyry Cu-Mo-Au-Ag Deposit, Panama: Economic Geology, 116, in the press.

Reed, D. L., Silver, E. A., 1995, Sediment dispersal and accretionary growth of the North Panama deformed belt, in, Mann, P. (ed), Geologic and Tectonic Development of the Caribbean Plate Boundary in Southern Central America: Geological Society of America Special Paper, 295, 213-223. 
Restrepo, V., 1886, A Study of the Gold \& Silver Mines of Colombia. English translation by C. W. Fisher: New York, Colombian Consulate. Restrepo, V., 1888, Estudio Sobre las Minas de Oro y Plata de Colombia: Reprinted in 1952, Bogotá, Colombia, Banco de la Republica.

Richards, J. P., 2011, High Sr/Y arc magmas and porphyry $\mathrm{Cu} \pm \mathrm{Mo} \pm \mathrm{Au}$ deposits: just add water: Economic Geology, 106, 1075-1081.https://doi.org/10.2113/ econgeo.106.7.1075

Richards, J. P., Kerrich, R., 2007, Adakite-like rocks: Their diverse origins and questionable role in metallogenesis: Economic Geology, 102, 537-576. https://doi.org/10.2113/ gsecongeo.102.4.537

Riddell, G. C., 1927, Is mining to thrive again in Panama? Engineering and Mining Journal, 124 (16, 17), 604-610, 649-653.

Roberts, R. J., Irving, E. M., 1957, Mineral Deposits of Central America, with a section on Manganese Deposits of Panama: United States Geological Survey Bulletin, 1034.

Rooney, T.O., Franceschi, P., Hall, C., 2010, Water saturated magmas in the Panama Canal region - a precursor to adakite-like magma generation?: Contributions to Mineralogy and Petrology, 161, 373-388. https://doi. org/10.1007/s00410-010-0537-8

Sears, J. D., 1919, Deposits of Manganese Ore in Costa Rica and Panama: United States Geological Survey Bulletin, 710-C, 61-91.

Sepp, M. D., Dilles, J. H., 2018, Structural Evolution, Vein Orientation, and Paragenesis of the Botija Porphyry Cu-Mo(Au) Deposit, Panama: Economic Geology, 113, 857-890. https://doi.org/10.5382/ econgeo.2018.4574

Sheridan, J. F., 1926, Gold areas of the province of Panama: Engineering and Mining Journal, 122(26), 1027-1028.

Sides, E. J., 1984, Effect of barren dykes on ore potential at Cerro Colorado porphyry copper deposit, Panama: Transactions of the Institution of Mining \& Metallurgy, 91, B219-B223.
Sillitoe, R. H., 2002, Rifting, bimodal volcanism and bonanza gold veins: SEG Newsletter, 48, 24-26.

Sillitoe, R. H., 2010, Porphyry Copper Systems: Economic Geology, 105, 3-41. https://doi. org/10.2113/gsecongeo.105.1.3

Simon, J., 1914. Manganese mines located near harbor of Nombre de Dios, Panama: Report for Panaminas, Inc., University of Wyoming, American Heritage Center, Thayer Lindslay Papers, Box 203, Folder 5, 14 p.

Simons, F. S., 1957, Manganese Deposits of Panama, in Roberts, R. J., Irving, E. M., Mineral Deposits of Central America, with a section on Manganese Deposits of Panama: United States Geological Survey Bulletin, 1034, 106-135.

Simmons, S. F., White, N. C., John, D. A., 2005, Geological characteristics of epithermal precious and base metal deposits: Economic Geology 100th Anniversary Volume, 485-522.

Singer, D. A., 1995, World class base and precious metal deposits - a quantitative analysis: Economic Geology, 90, 88-104. https://doi. org/10.2113/gsecongeo.90.1.88

Spatz, D. M., 1979, Potassium-argon age of the Cerro Colorado porphyry copper deposit, Panama - a discussion: Economic Geology, 74, 693-695. https://doi.org/10.2113/ gsecongeo.74.3.693

Speidel, F., Faure, S., Smith, M. T., McArthur, G. E., 2001, Exploration and Discovery at the Petaquilla Copper-Gold Concession, Panama, Central America: Society of Economic Geologists Special Publication, 8, 349-362. https://doi.org/10.5382/sp.08.23

Stranaham, D. M., 1941, Isthmian Corporation: Report, University of Wyoming, American Heritage Center, Thayer Lindslay Papers, Box 203, Folder 7, 2 p.

Swedish Geological International (SGI), 1991a, Geologia y ocurrencias de minerales en tres sectores en Panama. Informe Final, Parte I: unpublished report.

Swedish Geological International (SGI), 1991b, 
Mapeo geoquimico en tres sectores en Panama. Informe Final, Parte II: unpublished report.

Taylor, R. C., 1852, Substance of notes made during a geological reconnoissance [sic] in the auriferous porphyry region next to the Caribbean Sea, in the Province of Veraguas and Isthmus of Panama: Journal of the Academy of Natural Sciences of Philadelphia, 2nd Series, 2, 81-86.

Tippett, M. C., Trever, P. F., 1989, The Isthmus of Panama. A Forgotten El Dorado: Society of Mining Engineers Preprint, 89-56.

Tistl, M., 1994, Geochemistry of Platinum-Group Elements of the Zoned Ultramafic Alto Condoto Complex, Northwest Colombia: Economic Geology, 89, 158-167. https:// doi.org/10.2113/gsecongeo.89.1.158

Tistl, M., Burgath, K. P., Höhndorf, A., Kreuzer, H., Muñoz, R., Salinas, R., 1994, Origin and emplacement of Tertiary ultramafic complexes in northwest Colombia: Evidence from geochemistry and K-Ar, Sm-Nd and Rb-Sr isotopes: Earth and Planetary Science Letters, 126, 41-59. https://doi. org/10.1016/0012-821X(94)90241-0

Torrey, G. E., Keenan, J., 1994, Cerro Quema Project, Panama, in Bloom, L. (ed), Prospecting in Tropical and Arid Terranes short course: Toronto, Ontario, Prospectors and Developers Association of Canada, 5-6 March 1994.

Tortelli, G., Lightwood, G., Brown, D., MacMahon, C., Hull, A., Gorman, M., Sutcliffe, R., Kuchling, K., Yassa, A., Wu, Y., Burga, D., Armstrong, T., 2014, Gerro Quema Project - Pre-Feasibility Study on the La Pava and Quemita Oxide Gold Deposits, 10,000 tpd Heap Leach: NI 43-101 technical report by $\mathrm{P} \& \mathrm{E}$ Mining Consultants Inc., Golder Associates Inc. \& Kappes, Cassiday and Associates for Pershimco Resources Inc.

Tower, G. W., 1963, Cana mine, Panama: Report for Mauricio Hochschild, University of Wyoming, American Heritage Center, Thayer Lindslay Papers, Box 110, F. 1, 8 p.
Trenkamp, R., Kellogg, J. N., Freymueller, J. T., Mora, H. P., 2002, Wide plate margin deformation, southern Central America and northwestern South America, CASA GPS observations: Journal of South American Earth Sciences, 15, 157-171. https://doi. org/10.1016/S0895-9811(02)00018-4

Turner, S. J., Flindell, P. A., Hendri, D., Hardjana, I., Lauricella, P. F., Lindsay, R. P., Marpaung, B., White, G. P., 1994, Sediment-hosted gold mineralization in the Ratatotok district, North Sulawesi, Indonesia: Journal of Geochemical Exploration, 50, 317-336.

Turner, S. J., Garwin, S. A., Hofstra, A. H., 2002, Mesel SRHDG deposit and low-sulfidation gold veins in the Ratatotok district, north Sulawesi, Indonesia: Denver, Colorado, Geological Society of America, in 2002 Denver Annual Meeting, October 27-30, 2002, (abstract), Paper No. 63-7.

United Nations (UN), 1969, Results of detailed investigations in the Azuero area, Panama: United Nations Development Program report to the Government of the Republic of Panama.

United Nations (UN), 1972a, Reconnaissance Geochemical Survey of Bocas del Toro, Majé, Pirre and San Blas-Darien. Panama Mineral Survey (Phase II), Technical Report No. 2: New York, United Nations.

United Nations (UN), 1972b, Preliminary investigation of copper, gold and related mineralization in San Blas and other selected areas in Panama. Mineral Survey (Phase II) Republic of Panama, Technical Report No. 3: New York, United Nations Development Programme.

United Nations (UN), 1972c, Reconocimiento de las mineralizaciones de cobre y oro en la región del Río Pito, Comarca de San Blas. Proyecto Minero (Fase II) Panama, Informe Tecnico No. 4: New York, United Nations Development Programme.

United Nations (UN), 1981, Exploracion para cobre y oro en Rio Pito, Panama: New York, United Nations Development Programme. 
Wahl, G. H., 2005, Independent technical report and resource estimate of the Molejon gold project, Colon Province, Panama: NI 43101 technical report by SRK Consulting (Canada) Inc. for Petaquilla Minerals Ltd.

Webber, A. P., Roberts, S., Taylor, R. N., Pitcairn, I. K., 2013, Golden plumes: Substantial gold enrichment of oceanic crust during ridgeplume interaction: Geology, 41, 87-90. https://doi.org/10.1130/G33301.1

Wegner, W., Wörner, G., Harmon, R. S., Jicha, B. R., 2011 , Magmatic history and evolution of the Central American Land Bridge in Panama since Cretaceous times: Geological Society of America Bulletin, 123, 703-724. https://doi.org/10.1130/B30109.1

Westbrook, G. K., Hardy, N. C., Heath, R. P., 1995, Structure and tectonics of the Panama-Nazca plate boundary, in Mann, P. (ed), Geologic and Tectonic Development of the Caribbean Plate Boundary in Southern Central America: Geological Society of America Special Paper, 295, 91-109.

Whattam, S. A., Montes, C., McFadden, R. R., Cardona, A., Ramirez, D., Valencia, V., 2012, Age and origin of earliest adakiticlike magmatism in Panama: Implications for the tectonic evolution of the Panamanian magmatic arc system: Lithos, 142-143,
226-244. https://doi.org/10.1016/j. lithos.2012.02.017

White, D. C., 1994, Geology and mineralization of the Santa Rosa gold deposits, Panama: Mining Engineering, April 1994, 346-349.

Wilmot, R. C., 1960, Alumina and bauxite: U.S. Bureau of Mines Bulletin, 585, 15-26.

Wleklinski, S., 1969, Gold deposits of northern Veraguas, Republic of Panama. United Nations Development Programme, Mineral Survey of the Azuero Area: New York, United Nations Development Programme.

Woakes, E. R., 1895, Notes on the Espiritu Santo Mine at Cana; Its Drainage and Recovery: Transactions of the Institution of Mining \& Metallurgy, 3, 285-297.

Woakes, E. R., 1899, Modern Gold-Mining in the Darien. Notes on the Reopening of the Espiritu Santo Mine at Cana: Transactions American Institution of Mining Engineers, 29, 249-280.

Woakes, E. R., 1923, The Darien Gold Mine, Panama: The Mining Magazine, 270-278.

Woodring, W. P., 1957, Geology and Paleontology of Canal Zone and Adjoining Parts of Panama: Geology and Descriptions of Tertiary Molluscs (Gastropods: Trochidae to Turritellidae): United States Geological Survey Professional Paper, 306-A.

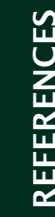

